\title{
17. NANNOFOSSIL BIOSTRATIGRAPHY OF THE SOUTHWEST PACIFIC DEEP SEA DRILLING PROJECT, LEG 30
}

\author{
Samir Shafik, Department of Geology and Mineralogy, \\ The University of Adelaide, Adelaide, South Australia
}

\section{INTRODUCTION}

Calcareous nannofossils occur in 225 of the 230 sedimentary cores recovered at five sites during Leg 30 of the Deep Sea Drilling Project; locations of sites are shown in Figure 1. Only light microscopy was used to study the nannofossil assemblages. The biostratigraphic assessments of the holes are deduced from the study of their nannofossil contents are summarized in Table 1. Species checklists are compiled for Sites 285, 286, 287, and the Cenozoic of Sites 288 and 289 and presented in Tables 2, 3, 4, 5, and 6. Unconformities revealed by this study are documented and graphically summarized in Tables 7 and 8 .

\section{NANNOFOSSIL ZONES}

The nannofossil biostratigraphic schemes in current use are based (a) on the bases and tops of ranges of selected species (e.g., Gartner, 1974) and (b) with the addition of variations in the abundance of a given species (e.g., Bukry, 1973).

The ease with which nannofossils can be reworked presents a special problem. In many cases, there is a pronounced gap in known stratigraphic ranges between apparently autochthonous and apparently allochthonous specimens; differences in preservation among specimens with similar response to dissolution provide further clues; mixing of near-shore elements into oceanic sediments can indicate the same thing. However, in the Pliocene and upper Miocene of Leg 30, routine biostratigraphic analysis has led to inconsistencies and confusion. The reason seems to be short upward reworking without the usual, more or less clear evidence for mixing. This is discussed for the relevant sites in the appropriate chapters. Site 289 is an exception; only minor reworking was noticed.

Accordingly, the practice of lumping zones defined by "extinctions" into zonal intervals based on initial appearances (up-sequence) is followed. Also, the defining events for zones used here are initial appearances wherever possible rather than "extinctions," because initial appearances are not obscured by reworking. Thus, the general approach in this cored material is precisely opposite to the approach used for subsurface material (other than core) where downhole contamination occurs.

The nannofossil zonation used for Leg 30 material is indicated below. Reworking, poor preservation, and/or unconformities hinder the recognition of the total extent of some zones. Data for constructing the zones are derived from all available sources, special attention being paid to the works of Bukry (1973) a, b, d, Gartner (1974), and Roth (1973). Only two events are "new" in the sense that they have not, to the author's knowledge, been used previously to define biostratigraphic units. Zones are listed down-section but defined up-section, i.e., lower boundary then upper boundary.

Emiliania huxleyi/Gephyrocapsa oceanica Zonal Interval (age: Pleistocene-Holocene)

The interval from the base range of Gephyrocapsa oceanica to top of section. The interval is equivalent to the combined Emiliania huxleyi and Gephyrocapsa oceanica zones used by Bukry (1973d). E. huxleyi is usually difficult to identify under the light microscope, and correlation based on its base range is likely to be unreliable.

\section{Gephyrocapsa caribbeanica Zone (age: Early Pleistocene)}

The interval from the base range of Gephyrocapsa caribbeanica to the base range of Gephyrocapsa oceanica. The zone is equivalent to the G. caribbeanica Subzone of Bukry (1973d). Distinction between $G$. oceanica and $G$. caribbeanica was based on taxonomic discussion by Bukry (1973b).

\section{Pseudoemiliania lacunosa Zone (age: Early Pleistocene)}

The range of Pseudoemiliania lacunosa between the top range of Discoaster brouweri (below) and the base range of Gephyrocapsa caribbeanica (above). This characterization is a poor one since it relies on the absence of two index species. The top range of Cyclococcolithina macintyrei occurs near the top of the zone.

The zone correlates with the lower part of the Pseudoemiliania lacunosa Zone proposed by Gartner (1969) and with the Emiliania annula Subzone of Bukry (1973d). The lower boundary of the zone approximates the Pliocene/Pleistocene boundary. In cases of intense reworking, recognition of this event becomes impossible, and recognition of the Pliocene/Pleistocene boundary is consequently hindered. However, the zone is a short interval of about 0.2 m.y. (see Bukry, 1973b) and therefore the base range of Gephyrocapsa caribbeanica may be used as a guide for locating tentatively the Pliocene/Pleistocene boundary.

\section{Discoaster brouweri Zone (age: Late Pliocene)}

The interval from the top range of "Discoaster" pentaradiatus to the top range of Discoaster brouweri. The zone is correlative with the Cyclococcolithina macintyrei Subzone of Bukry (1973d).

\section{"Discoaster" pentaradiatus Zone (age: Late Pliocene)}

The interval from the top range of Discoaster tamalis to the top range of "Discoaster" pentaradiatus. 


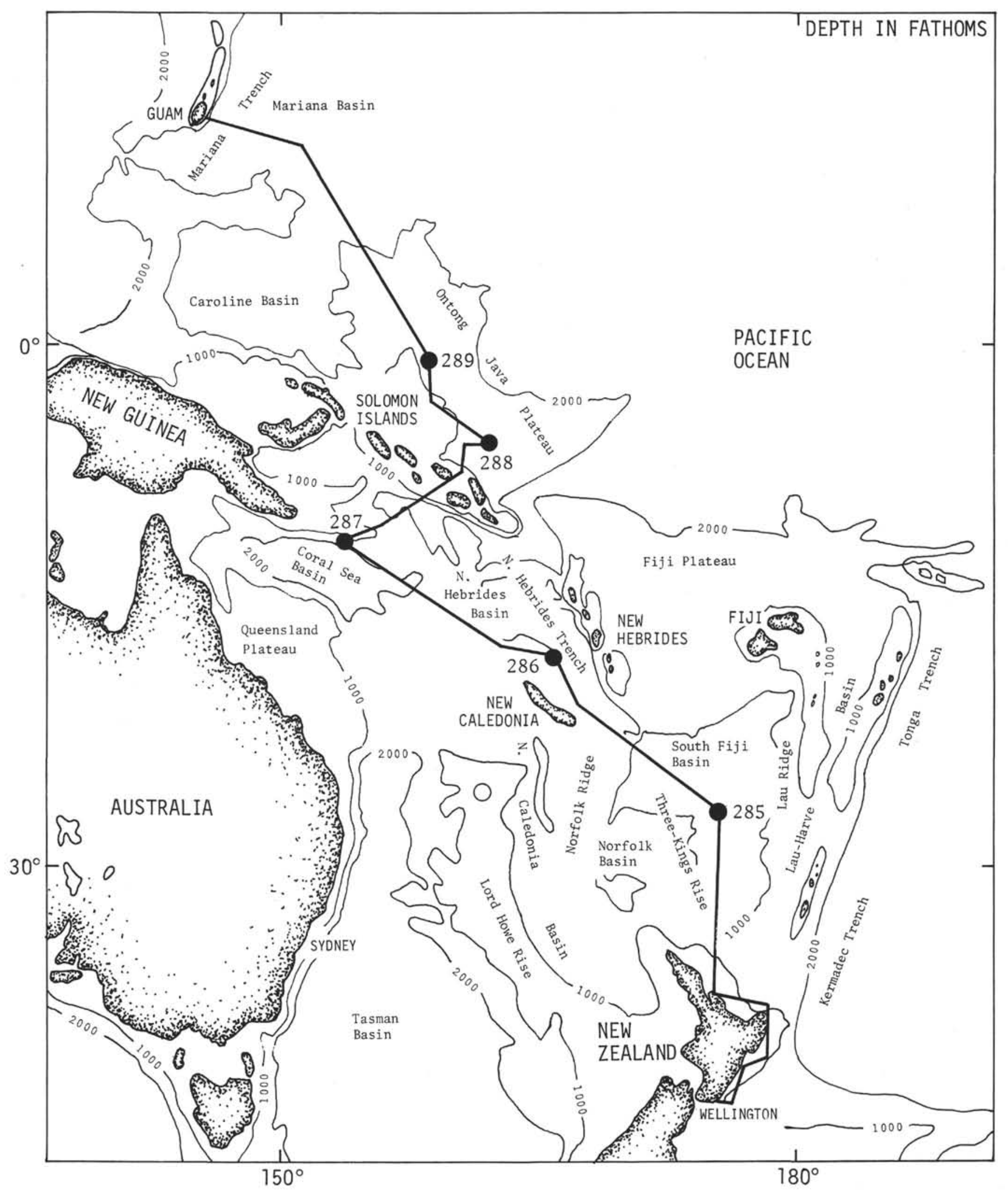

Figure 1. Location of sites drilled during Leg 30. 
NANNOFOSSIL BIOSTRATIGRAPHY

TABLE 1

Biostratigraphic Assessments of Leg 30 Cores From Southwest Pacific Region

\begin{tabular}{|c|c|c|c|c|c|c|c|c|c|c|}
\hline \multirow{2}{*}{$\begin{array}{l}\text { Series or } \\
\text { Subseries }\end{array}$} & \multirow{2}{*}{ Nannofossil ZonesiSubzones } & \multicolumn{2}{|c|}{ South Fiji Basin } & \multirow{2}{*}{$\frac{\text { New Hebrides }}{286}$} & \multirow{2}{*}{$\frac{\text { Coral Sea Basin }}{287}$} & \multicolumn{3}{|c|}{ Ontong-Java Platesu } & \multirow{2}{*}{\multicolumn{2}{|c|}{$288 \mathrm{C}$}} \\
\hline & & 285 & $285 \mathrm{~A}$ & & & 288 & $288 \mathrm{~A}$ & 2888 & & \\
\hline \multirow{3}{*}{$\begin{array}{l}\text { Holocene } \\
\text { Pleistocene }\end{array}$} & Emilianie huxteyt:Gephyrocapsa oceanica & \multirow{4}{*}{$\stackrel{2 \cdot 1}{1}$} & & $\begin{array}{l}1.1 .110 .111 \mathrm{~cm} \\
24.32 .33 \mathrm{~cm}\end{array}$ & $\begin{array}{c}1-2,130-131 \mathrm{~cm} \\
4 . \mathrm{CC}\end{array}$ & $\begin{array}{l}1-1,30-31 \mathrm{~cm} \\
2 \cdot 2,24 \cdot 25 \mathrm{~cm}\end{array}$ & & & & $\begin{array}{l}1-1.30 .31 \mathrm{~cm} \\
2-6.30-31 \mathrm{~cm}\end{array}$ \\
\hline & Gephyrocopso caribbeanica & & & $\begin{array}{l}2.5 .125 \cdot 126 \mathrm{~cm} \\
2 . \mathrm{CC} \\
\end{array}$ & $\begin{array}{l}5-3,120-121 \mathrm{~cm} \\
6-1.120-121 \mathrm{~cm}\end{array}$ & $\begin{aligned} 2-2.50 \mathrm{~cm} \\
2-5,30-31 \mathrm{~cm} \\
\end{aligned}$ & & & & $\begin{array}{r}2.18 \\
+3.110-111 \mathrm{~cm} \\
\end{array}$ \\
\hline & Pserudoemiliania iacimose & & & $?{ }_{3.3}^{3-1}$ & $6.2 .130 .131 \mathrm{~cm}$ & $2, \mathrm{CC}$ & & & & $\begin{array}{l}4-30.31 \mathrm{~cm} \\
46,30-31 \mathrm{cmi} \\
\end{array}$ \\
\hline \multirow{3}{*}{ Upper } & Discoesster brouswert & & & $\begin{array}{c}3-4,95.96 \mathrm{~cm} \\
3.5 .2 \mathrm{~cm}\end{array}$ & 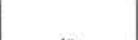 & & & & & $\begin{array}{c}4.8 \mathrm{~T} \\
7.2 .35 \cdot 36 \mathrm{~cm}\end{array}$ \\
\hline & "Discoaster" pentaredianus & \multirow[b]{3}{*}{$L_{0}$} & & $\begin{array}{l}3.5,120.121 \mathrm{~cm} \\
3 . \mathrm{CC} \\
\end{array}$ & to & to & & & & $\begin{array}{c}7.2,120-121 \mathrm{~cm} \\
7.6 .30-31 \mathrm{~cm}\end{array}$ \\
\hline & Discooster tamalis & & & & $8 \cdot 1,10-11 \mathrm{~cm}$ & $5, \mathrm{CC}$ & & & & $\begin{array}{c}7, \mathrm{CC} \\
10-3,30-31 \mathrm{~cm}\end{array}$ \\
\hline \multirow{3}{*}{ Lower } & Reticulofenertra psendoumbilices & & & & & & & & & $\begin{array}{c}10-3.30 .31 \mathrm{sm} \\
13.6 \mathrm{C}\end{array}$ \\
\hline & Cenatolithus negonus & $2 \cdot 2$ & & $\begin{array}{c}4 \cdot 1,120-121 \mathrm{~cm} \\
4 . \mathrm{CC}\end{array}$ & & & & & & $\begin{array}{c}1+1.30 .31 \mathrm{~cm} \\
15.68\end{array}$ \\
\hline & Cerstolithus acutus & & & & & & & & & $\begin{array}{c}16-1,120-121 \mathrm{~cm} \\
16-4,30-31 \mathrm{~cm}\end{array}$ \\
\hline & tricarmiculatus $\quad$ Triquetrorhabdulat nuxosus & & & & & & & & & $\begin{array}{r}16-5,30-31 \mathrm{~cm} \\
17.3,120.121 \mathrm{~cm} \\
\end{array}$ \\
\hline Upper & Discoester quinquerramus & $\begin{array}{l}2 \cdot 3,77 \cdot 78 \mathrm{~cm} \\
3-1,36-37 \mathrm{~cm}\end{array}$ & & & & $\begin{array}{r}6 \cdot 1,120-121 \mathrm{~cm} \\
6-6,30-31 \mathrm{~cm} \\
\end{array}$ & & & & $\begin{array}{r}17.4 .120-121 \mathrm{~cm} \\
25-1.120-121 \mathrm{~cm} \\
\end{array}$ \\
\hline & Discoaster bergarenif & & & & & & & & & $27.3 .120-121 \mathrm{~cm}$ \\
\hline & Discoaster neohamatus & $\begin{array}{c}3-2,51-52 \mathrm{~cm} \\
4 . \mathrm{CC}\end{array}$ & & & & $\begin{array}{l}6-6.120-121 \mathrm{~cm} \\
7-1,132-133 \mathrm{~cm}\end{array}$ & & & & $\begin{array}{c}27-30.31 \mathrm{~cm} \\
334.120 \cdot 121 \mathrm{~cm}\end{array}$ \\
\hline & \begin{tabular}{|l} 
Catinaster \\
colyculus
\end{tabular} & $\begin{array}{l}5 \cdot 1,30-31 \mathrm{~cm} \\
5, \mathrm{CC}\end{array}$ & & $\begin{array}{l}\text { Almost } \\
\text { harten }\end{array}$ & & $\begin{array}{l}7.2 .120-121 \mathrm{~cm} \\
8-1.118-119 \mathrm{~cm} \\
\end{array}$ & & & $1.0 \mathrm{C}$ & $\begin{array}{r}33-5.30-31 \mathrm{~cm} \\
35.4 .120-121 \mathrm{~cm} \\
\end{array}$ \\
\hline & 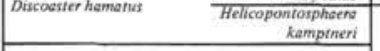 & & & & פू & & & & & $\begin{array}{l}35 . \mathrm{CC} \\
36 \mathrm{CC} \\
\end{array}$ \\
\hline Middle & Catinaster coalinut & & & & & & & & & $\begin{array}{l}37-1,30-31 \mathrm{~cm} \\
37-6.35-36 \mathrm{~cm}\end{array}$ \\
\hline$\frac{8}{2}$ & Discoasster exilis & & $\begin{array}{l}1.1,124-125 \mathrm{~cm} \\
5.5 .9 \cdot 10 \mathrm{~cm}\end{array}$ & $\begin{array}{l}\text { (greatest part of } \\
\text { Core } 5\end{array}$ & & $\begin{array}{c}8 . \mathrm{cc} \\
10-1.94 .95 \mathrm{~cm}\end{array}$ & & $1.0 C$ & & $\begin{array}{l}37-6.120-121 \mathrm{~cm} \\
47-4.30-31 \mathrm{~cm}\end{array}$ \\
\hline & Sphenolithus heteromorthus & & $\begin{array}{l}5.0 \mathrm{C} \\
7.6 .130 \mathrm{~cm}\end{array}$ & $\begin{array}{l}\text { 1s probably of } \\
\text { Miocene age) }\end{array}$ & & $10-2,123-124 \mathrm{~cm}$ & & & & $\begin{array}{r}47.5,30-31 \mathrm{~cm} \\
53 \cdot 3,120-121 \mathrm{~cm}\end{array}$ \\
\hline & Sphenolithus heteromorphus & & & & & 11.cc & & & & $\begin{array}{c}53-4.120-121 \mathrm{~cm} \\
57 . \mathrm{CC} \\
\end{array}$ \\
\hline Lowet & Sphenolithus belemnos & & & & & & & & & $\begin{array}{l}38-1.30-31 \mathrm{~cm} \\
60 . \mathrm{CC} \\
\end{array}$ \\
\hline Lowet & Discoester druggeit & & & & & & $\begin{array}{l}1-1.39 .40 \mathrm{~cm} \\
1 . \mathrm{CC}\end{array}$ & & & $61-1.30-31 \mathrm{~cm}$ \\
\hline & $\begin{array}{l}\text { Triquetrorhabdulus } \\
\text { cerinatus }\end{array}$ & & & & & & $\begin{array}{l}2 \cdot 1.134 \cdot 135 \mathrm{~cm} \\
2 . \mathrm{CC}\end{array}$ & & & to \\
\hline & Cyclicargolithus abisectus & & & & & & & & & $78 . \mathrm{CC}$ \\
\hline & Sphenolithut ciperoensis & & & $\begin{array}{l}5 . \mathrm{CC} \\
6 . \mathrm{CC}\end{array}$ & \begin{tabular}{|c|}
$10-2.4-5 \mathrm{~cm}$ \\
$10-4.30-31 \mathrm{~cm}$ \\
\end{tabular} & & & & & $\begin{array}{c}79.1 .60-61 \mathrm{~cm} \\
85 . \mathrm{CC} \\
\end{array}$ \\
\hline & Sphenolithus distentus & & & $\begin{array}{l}7.1,120-121 \mathrm{~cm} \\
7-6,120-121 \mathrm{~cm}\end{array}$ & $\begin{array}{l}10-1,120-121 \mathrm{~cm} \\
11-0,24-25 \mathrm{~cm}\end{array}$ & & $\begin{array}{c}3-1.110-111 \mathrm{~cm} \\
4 \mathrm{CCC}\end{array}$ & & & $\begin{array}{c}86 \cdot 2.120-121 \mathrm{~cm} \\
91 . \mathrm{CC}\end{array}$ \\
\hline Otigocene. & Sphenotithus predistentus & & & $7 . \mathrm{CC}$ & & & $\begin{array}{l}5.1 .81 .82 \mathrm{~cm} \\
6-1.74 .76 \mathrm{~cm}\end{array}$ & & & $\begin{array}{l}92-1.120-121 \mathrm{~cm} \\
100-1.50-51 \mathrm{~cm}\end{array}$ \\
\hline & Reticulofenestra hillare & & & $\begin{array}{l}7 . \mathrm{CC} \\
8.0 \mathrm{C}\end{array}$ & & & $6.1 .115 .116 \mathrm{~cm}$ & & & $\frac{100-1.122 .123 \mathrm{~cm}}{100 . \mathrm{CC}}$ \\
\hline & Cydococcolithina formosa & & & $\begin{array}{l}8.0 \mathrm{c} \\
9.1 .55 .56 \mathrm{~cm} \\
9.5 .45 .46 \mathrm{~cm}\end{array}$ & & & & & & $\frac{100.0 \mathrm{c}}{101-1.64-66 \mathrm{cmi}}$ \\
\hline & Upper & & & $9.5 .65 .66 \mathrm{~cm}$ & & & & & & 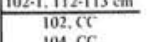 \\
\hline Upper & Discooster berbodiensix & & & $\frac{10-4,25 \cdot 26 \mathrm{~cm}}{10-4.135 \cdot 136 \mathrm{~cm}}$ & & & & & & \begin{tabular}{|l}
$104 . \mathrm{CC}$ \\
$105 . \mathrm{CC}$
\end{tabular} \\
\hline & 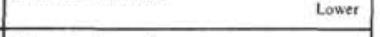 & & & $17.1 .15 \cdot 16 \mathrm{~cm}$ & & & & & & $108-1.74 .75 \mathrm{~cm}$ \\
\hline & Discoaster saipanentis & & & $17.2 .97 .98 \mathrm{~cm}$ & & & & & & $\begin{array}{c}108.0 \mathrm{CC} \\
110-1.107-108 \mathrm{~cm}\end{array}$ \\
\hline & Cyclicargolithus reticulatus & & & $32-1.30-31 \mathrm{~cm}$ & & & & & & $\begin{array}{l}110 . \mathrm{CC} \\
112 . \mathrm{CC} \\
\end{array}$ \\
\hline & Rericulofenestra umbilica & & & $\begin{array}{l}32-2.43-44 \mathrm{~cm} \\
33 . \mathrm{CC}\end{array}$ & & & & & & \\
\hline Middle & Chiosmolithus sizar & & & & \begin{tabular}{|c|}
$11-0.29 .30 \mathrm{~cm}$ \\
$11 . \mathrm{CC}$ \\
\end{tabular} & & & & & $113.1,117.118 \mathrm{~cm}$ \\
\hline & Nannoterrine fulgens & & & & $\begin{array}{l}12-1.100-101 \mathrm{~cm} \\
13 . \mathrm{CC}\end{array}$ & & Cote 7 & & & \\
\hline & Discouster whbladoensis $\quad$ Rhabdosphacra inflate & & & & \begin{tabular}{|l|}
$\begin{array}{l}14-1.100-101 \mathrm{~cm} \\
14 . \mathrm{CC}\end{array}$ \\
\end{tabular} & & Unrecosered & & & \\
\hline & $\begin{array}{l}\text { Discouster atublodoensis } \\
\text { Discoesteroides kuepperi }\end{array}$ & & & & $\begin{array}{c}15 \cdot 1.100-101 \mathrm{~cm} \\
15 . \mathrm{CC} \\
\end{array}$ & & & & & \\
\hline Lowet & Discoaster lodoensis & & & & & & & & & $\begin{array}{l}114-1.148 .150 \mathrm{~cm} \\
115 \cdot 1.55-56 \mathrm{~cm} \\
\end{array}$ \\
\hline Lowet & Tribrachiatus orthotrylus & & & & 16.1 & & & & & \\
\hline & Discoaster diastypus & & & & & & & & & 7115.cc \\
\hline & Discoaster multiradiatus & & & & & & & & & $\begin{array}{c}116-1.140 .143 \mathrm{~cm} \\
119 . \mathrm{CC} \\
\end{array}$ \\
\hline & Discoaster nobilis & & & & & & & & & \\
\hline & Discasster mohlent & & & & & & & & & \begin{tabular}{|c|}
$120-1,80-81 \mathrm{~cm}$ \\
$120-1,148-150 \mathrm{~cm}$ \\
\end{tabular} \\
\hline Paleocene & Heliolithus kleinpeltin & & & & & & $\begin{array}{l}8.1 .102 \cdot 103 \mathrm{~cm} \\
8.2 .102-103 \mathrm{~cm} \\
8\end{array}$ & & & $120 . \mathrm{CC}$ \\
\hline & Fesciculithus tympaniformis & & & & & & & & & $121-1.125 \cdot 126, \mathrm{~cm}$ \\
\hline & Cyclococcolithina robuste & & & & & & $8 \cdot 2,122-123 \mathrm{~cm}$ & & & $121-2,62-63 \mathrm{~cm}$ \\
\hline & Cruciplecolithus tenuis & & & & & & $\begin{array}{l}8.2 .138 .139 \mathrm{~cm} \\
8 . \mathrm{CC}\end{array}$ & & & $122-1$ (top) \\
\hline & Micule mure & & & & & & $9 \cdot 1.21 \cdot 22 \mathrm{~cm}$ & & & $122 \mathrm{CC}$ \\
\hline Maestrichtian & Lithraphidites quadratus & & & & & & $\begin{array}{l}9-2.100-102 \mathrm{~cm} \\
10-1.29 \cdot 30 \mathrm{~cm}\end{array}$ & & & $\begin{array}{c}126-1,135-136 \mathrm{~cm} \\
126 \text { (bottom) }\end{array}$ \\
\hline & Tetralithus trifidus & & & & & & $\begin{array}{l}10.1 .113 .114 \mathrm{~cm} \\
11 \cdot 2,29 \cdot 30 \mathrm{~cm} \\
\end{array}$ & & & $\begin{array}{c}127.1 .1311 .132 \mathrm{~cm} \\
129,0 C \\
\end{array}$ \\
\hline Campanian & Broinsonia parca & & & & & & $? 11-2,80-81 \mathrm{~cm}$ & & & $130 . \mathrm{CC}$ \\
\hline & Eiffellithus ougustus & & & & & & $\begin{array}{l}11 \cdot 2,100-102 \mathrm{~cm} \\
12-1,122 \cdot 125 \mathrm{~cm} \\
\end{array}$ & & & $\begin{array}{c}131-1,1-2 \mathrm{~cm} \\
131-1,30-31 \mathrm{~cm} \\
\end{array}$ \\
\hline Santonian & Gartnerago obliquum & & & & & & & & & \\
\hline Coniacian & Manthasterites turcanus & & & & & & \begin{tabular}{|c|}
$12 . \mathrm{CC}$ \\
$15 \cdot 2,129 \cdot 130 \mathrm{~cm}$ \\
\end{tabular} & & & \\
\hline 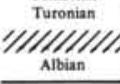 & 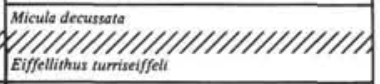 & & & & & & $\begin{array}{c}15 . \mathrm{CC} \\
\text { to } \\
28-1,65-66 \mathrm{~cm}\end{array}$ & & & \\
\hline Aptian & & & & & & & $\begin{array}{c}29 . \mathrm{CC} \\
30-1\end{array}$ & & & $\begin{array}{r}131 \cdot 1,149 \cdot 150 \mathrm{~cm} \\
132 \cdot 2,68 \cdot 70 \mathrm{~cm} \\
\end{array}$ \\
\hline
\end{tabular}


TABLE 2

Checklist of Calcareous Nannofossils Recovered at Site 285

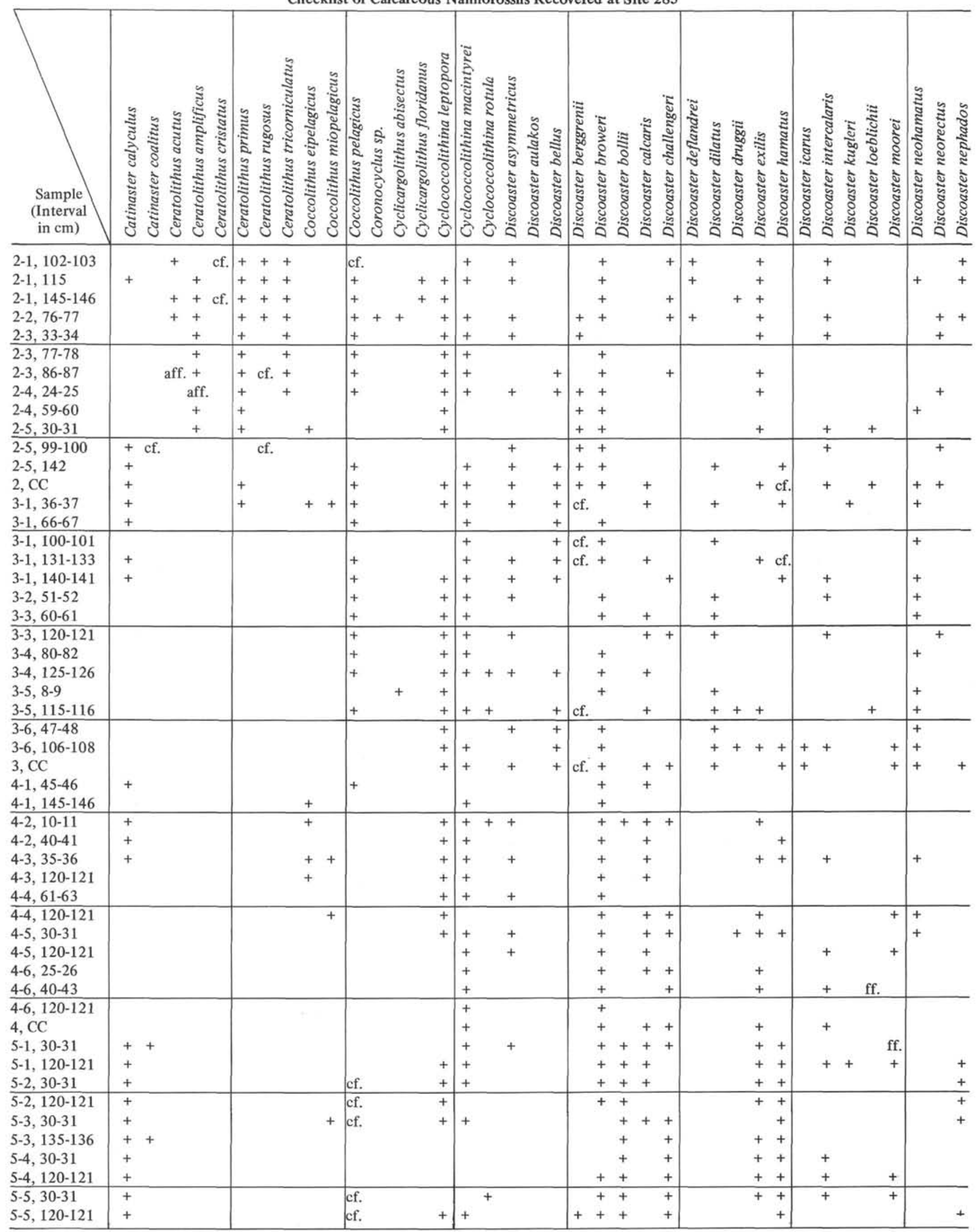


TABLE 2 - Continued

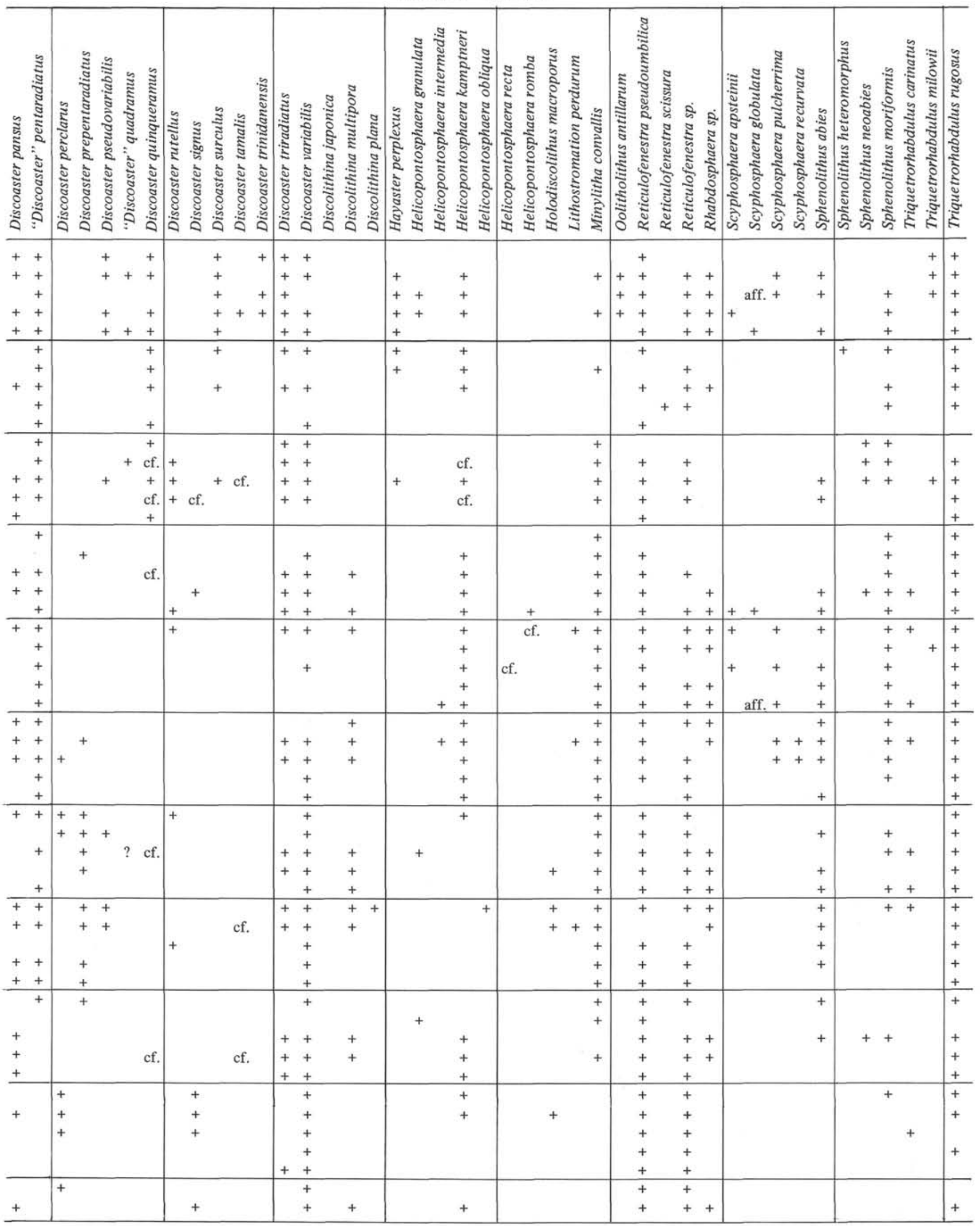


TABLE 2 - Continued

\begin{tabular}{|c|c|c|c|c|c|c|c|c|c|}
\hline $\begin{array}{c}\text { Sample } \\
\text { (Interval } \\
\text { in } \mathrm{cm})\end{array}$ & 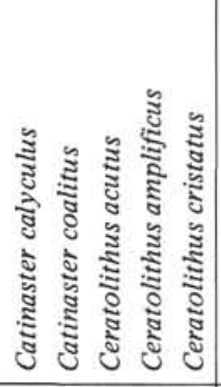 & 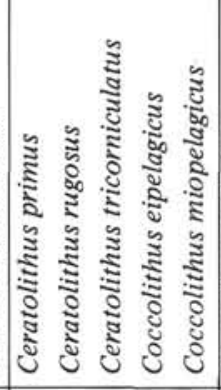 & 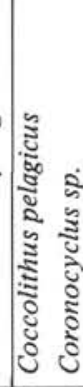 & 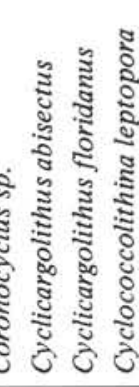 & 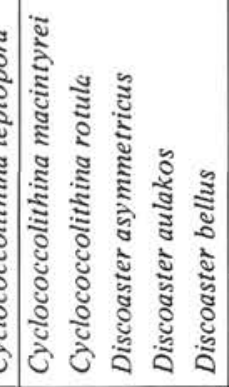 & 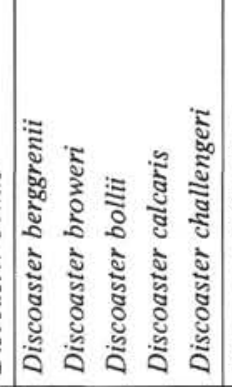 & 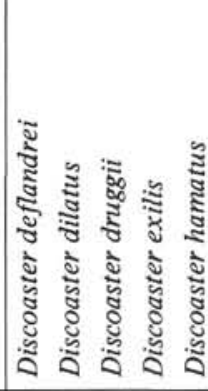 & 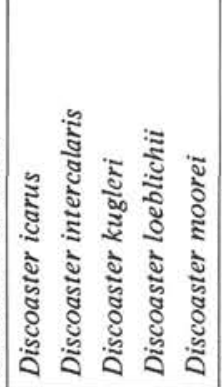 & 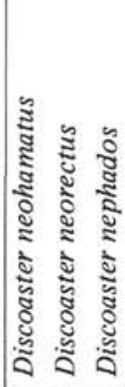 \\
\hline $\begin{array}{l}5-6,45-46 \\
5-6,130-131 \\
5, \mathrm{CC}\end{array}$ & $\begin{array}{l}++ \\
++ \\
++\end{array}$ & & $\begin{array}{l}\text { cf. } \\
\text { cf. }\end{array}$ & $\begin{array}{l}+ \\
+ \\
+\end{array}$ & $\begin{array}{l}++ \\
+ \\
+ \\
+\end{array}$ & 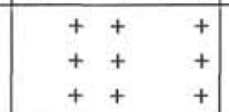 & $\begin{array}{r}+ \\
+ \\
++\end{array}$ & $\begin{array}{l}+ \\
+\end{array}$ & $\begin{array}{l}+ \\
+ \\
+\end{array}$ \\
\hline $\begin{array}{l}1 \mathrm{~A}-1,124-125 \\
1 \mathrm{~A}-1,138-139 \\
1 \mathrm{~A}-2,30-31 \\
1 \mathrm{~A}-3,25-26 \\
1 \mathrm{~A}-3,130-131\end{array}$ & & + & cf. & $\begin{array}{r}+ \\
+ \\
+ \\
+\end{array}$ & $\begin{array}{l}+ \\
+ \\
+ \\
+ \\
+ \\
+\end{array}$ & 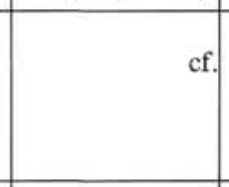 & $\begin{array}{l}+ \\
+ \\
+ \\
+\end{array}$ & $\begin{array}{l}+ \\
\text { cf. cf. } \\
+\end{array}+$ & \\
\hline \begin{tabular}{l|}
$\mathrm{A}-4,10-11$ \\
$1 \mathrm{~A}-6,66-67$ \\
$1 \mathrm{~A}, \mathrm{CC}$ \\
$2 \mathrm{~A}-1,99-101$ \\
$2 \mathrm{~A}, \mathrm{CC}$
\end{tabular} & & $\begin{array}{l}+ \\
+ \\
+\end{array}$ & cf. & $\begin{array}{l}+ \\
+ \\
+\end{array}$ & $\begin{array}{l}\text { cf. } \\
+ \text { cf. } \\
+ \\
+\end{array}$ & & $\begin{array}{r}++ \\
+\end{array}$ & ++ & \\
\hline $\begin{array}{l}3 \mathrm{~A}-1,110-111 \\
3 \mathrm{~A}-2,85-86 \\
3 \mathrm{~A}, \mathrm{CC} \\
4 \mathrm{~A}-1,108-110 \\
4 \mathrm{~A}-2,124-125 \\
\end{array}$ & & $\begin{array}{l}+ \\
+ \\
+ \\
+ \\
+\end{array}$ & $\begin{array}{l}\text { cf. } \\
\text { cf. }\end{array}$ & $\begin{array}{r}+ \\
+ \\
+ \\
+\end{array}$ & $\begin{array}{l}+ \\
+ \\
+ \\
+ \\
+\end{array}$ & $\begin{array}{ll}\text { ef. } & \\
\text { cf. } & + \\
+\end{array}$ & $\begin{array}{r}+ \\
+ \\
+\end{array}$ & + & \\
\hline \begin{tabular}{l|}
$\mathrm{A}, \mathrm{CC}$ \\
$5 \mathrm{~A}-1,110-112$ \\
$5 \mathrm{~A}-2,45-46$ \\
$5 \mathrm{~A}-3,82-83$ \\
$5 \mathrm{~A}-4,117-118$ \\
\end{tabular} & & $\begin{array}{l}+ \\
+ \\
+\end{array}$ & cf. & $\begin{array}{r}++ \\
++ \\
+++\end{array}$ & + & & $\begin{array}{ll}+ & \text { cf. }+ \\
\text { cf. } & \end{array}$ & & \\
\hline $\begin{array}{l}5 \mathrm{~A}-5,9-10 \\
5 \mathrm{~A}-5,106-107 \\
5 \mathrm{~A}, \mathrm{CC} \\
6 \mathrm{~A}-1,21-22 \\
6 \mathrm{~A}-3,25-26 \\
\end{array}$ & & $\begin{array}{r}+ \\
+ \\
+\end{array}$ & $\begin{array}{l}\text { cf. } \\
\text { cf. } \\
\text { cf. }\end{array}$ & $\begin{array}{l}+++ \\
+++ \\
+++ \\
++\end{array}$ & $\begin{array}{l}+ \\
+ \\
+\end{array}$ & + & & & \\
\hline $\begin{array}{l}6 \mathrm{~A}-5,129-131 \\
6 \mathrm{~A}, \mathrm{CC} \\
7 \mathrm{~A}-3,137-138 \\
7 \mathrm{~A}-4,10-11 \\
7 \mathrm{~A}-6,46-47 \\
7 \mathrm{~A}-6,130-131\end{array}$ & & $\begin{array}{l}+ \\
+ \\
+\end{array}$ & & $\begin{array}{l}+++ \\
+ \\
+++ \\
++ \\
+\end{array}$ & $\begin{array}{l}+ \\
+ \\
+ \\
+\end{array}$ & & $\begin{array}{l}+ \\
+ \\
+ \\
+\end{array}$ & & + \\
\hline
\end{tabular}

\section{Discoaster tamalis Zone (age: Late Pliocene)}

The total range of Discoaster tamalis.

The lower upper Pliocene boundary is tentatively drawn at the base of this zone (discussion in Bukry, 1973d).

The D. brouweri, "D." pentaradiatus, and D. tamalis zones are based on the sequential disappearance downsection of the nominate species and in case of reworking, their differentiation becomes impossible. Therefore, these zones, together with the $P$. lacunosa Zone are lumped into the Discoaster triradiatus/Pseudoemiliania lacunosa zonal interval delimited by the base ranges of Discoaster tamalis and barred Gephyrocapsa species ( $G$. caribbeanica). This interval corresponds roughly to the upper Pliocene.

\section{Reticulofenestra pseudoumbilica Zone (age: Early Pliocene)}

The interval from the last occurrence of nonbirefringent ceratoliths (Ceratolithus tricorniculatus and C. primus) to the base range of Discoaster tamalis.

The upper boundary as originally defined by the last occurrence of $R$. pseudoumbilica (Gartner, 1969), is rather difficult to determine because $R$. pseudoumbilica becomes quite rare and is usually represented by small specimens (Gartner, 1974 and own observation). Bukry (1973d) reinforces the recognition of this boundary by the disappearance of representatives of Sphenolithus. Discoaster tamalis first appears shortly before the disappearance of $R$. pseudoumbilica and Sphenolithus spp. 
TABLE 2 - Continued

\begin{tabular}{|c|c|c|c|c|c|c|c|c|c|c|c|}
\hline \multirow[t]{8}{*}{ 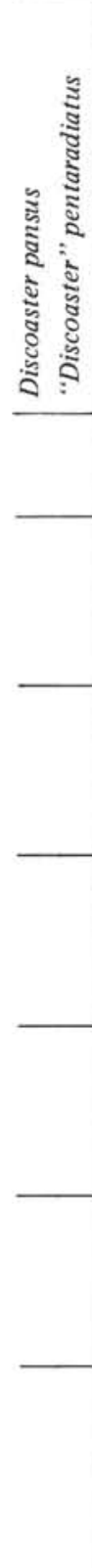 } & 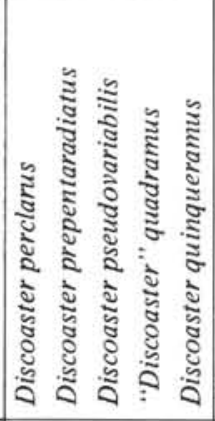 & 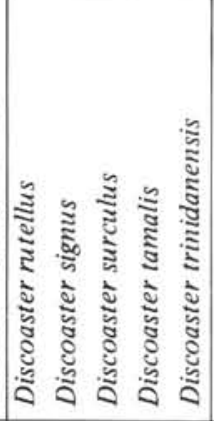 & 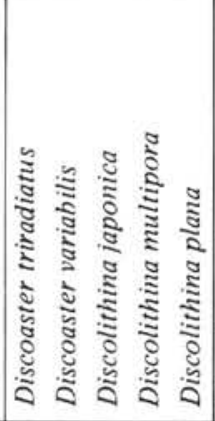 & 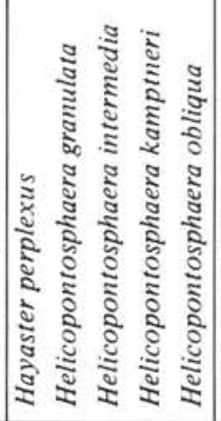 & 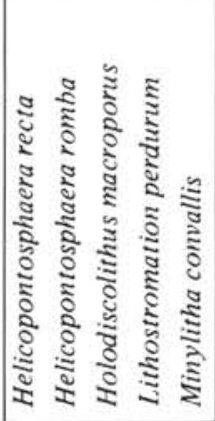 & 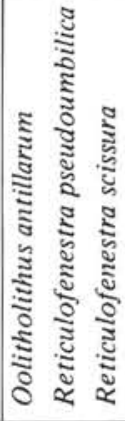 & 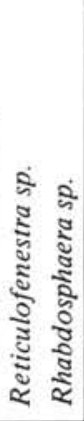 & 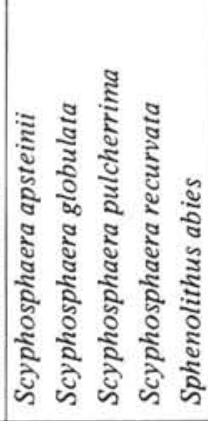 & 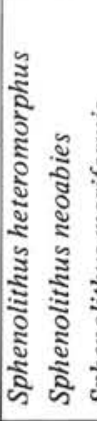 & 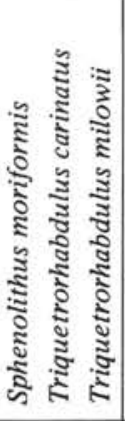 & 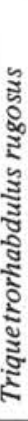 \\
\hline & + & $\begin{array}{l}+ \\
+\end{array}$ & $\begin{array}{rrr}+ & + & + \\
+ & + & + \\
+ & \\
\end{array}$ & $\begin{array}{l}+ \\
+\end{array}$ & + & $\begin{array}{l}+ \\
+ \\
+ \\
\end{array}$ & $\begin{array}{l}+ \\
++ \\
+\end{array}$ & + & + & & $\begin{array}{l}+ \\
+ \\
+\end{array}$ \\
\hline & + & + & $\begin{array}{ll}+ & + \\
+ & \\
+ & + \\
+ & \\
+ & + \\
\end{array}$ & $\begin{array}{l}+ \\
+ \\
+\end{array}$ & & $\begin{array}{l}+ \\
+ \\
+ \\
+ \\
+\end{array}$ & $\begin{array}{l}+ \\
+ \\
+ \\
+ \\
+ \\
\end{array}$ & + & $\begin{array}{l}+ \\
+ \\
+\end{array}$ & $\begin{array}{l}+ \\
+\end{array}$ & \\
\hline & $\begin{array}{l}+ \\
+ \\
+ \\
\text { cf. }\end{array}$ & & $\begin{array}{ll}+ & \\
+ & \\
+ & + \\
\text { cf. } & + \\
+ & +\end{array}$ & $\begin{array}{r}1 \\
+ \text { aff. } \\
+\quad \\
\end{array}$ & cf. + & $\begin{array}{l}+ \\
+ \\
+ \\
+ \\
+\end{array}$ & $\begin{array}{l}+ \\
+ \\
+ \\
+ \\
\end{array}$ & $\begin{array}{l}+ \\
+ \\
+\end{array}$ & & + & \\
\hline & & & 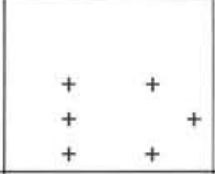 & $\begin{array}{l}+ \\
+ \\
+ \\
+ \\
+\end{array}$ & + & $\begin{array}{l}+ \\
+ \\
+ \\
+ \\
+\end{array}$ & $\begin{array}{l}+ \\
+ \\
+ \\
+ \\
+\end{array}$ & $\begin{array}{r}+\quad \text { aff. } \\
+ \\
+\end{array}$ & $\begin{array}{l}+ \\
+ \\
+ \\
+\end{array}$ & & \\
\hline & & & $\begin{array}{l}+ \\
+ \\
+ \\
+\end{array}$ & $\begin{array}{l}+ \\
+ \\
+ \\
+\end{array}$ & + & $\begin{array}{l}+ \\
+ \\
+ \\
+ \\
+\end{array}$ & + & & & $\begin{array}{l}+ \\
+ \\
+ \\
+\end{array}$ & \\
\hline & & + & $\begin{array}{lll} & & + \\
+ & & \\
+ & + & \\
+ & & +\end{array}$ & $\begin{array}{l}+ \\
+ \\
+ \\
+\end{array}$ & $\begin{array}{l}+ \\
+ \\
+ \\
+\end{array}$ & $\begin{array}{l}+ \\
+ \\
+ \\
+ \\
+\end{array}$ & & $\begin{array}{l}+ \\
+\end{array}$ & $\begin{array}{l}+ \\
+\end{array}$ & $\begin{array}{l}+ \\
+ \\
+\end{array}$ & \\
\hline & & & cf. & $\begin{array}{l}+ \\
+ \\
+ \\
+ \\
+\end{array}$ & & $\begin{array}{l}+ \\
+ \\
+ \\
+ \\
+ \\
+\end{array}$ & & + & $\begin{array}{l}+ \\
+ \\
+ \\
+\end{array}$ & $\begin{array}{l}+ \\
+ \\
+\end{array}$ & \\
\hline
\end{tabular}

The base range of D. tamalis is used here instead of the top ranges of $R$. pseudoumbilica and Sphenolithus spp. to avoid the biostratigraphic hazard caused by reworking.

\section{Ceratolithus rugosus Zone (age: Early Pliocene)}

The interval from the base range of Ceratolithus rugosus to the last occurrence of nonbirefringent ceratoliths.

This zone is equivalent to the $C$. rugosus Subzone of Bukry (1973d).

\section{Ceratolithus tricorniculatus Zone (age: Miocene-} Pliocene)

The interval from the top range of Discoaster quinqueramus to the base range of Ceratolithus rugosus.
The base and top ranges of Ceratolithus acutus and Triquetrorhabdulus rugosus, respectively, are near the base of the $C$. tricorniculatus Zone almost at the same level. Bukry (1973b, d) uses these criteria to subdivide an interval equivalent to the $C$. tricorniculatus Zone into the Triquetrorhabdulus rugosus and Ceratolithus acutus subzones and considers the boundary separating these subzones as the Pliocene/Miocene boundary.

\section{Discoaster quinqueramus Zone (age: Late Miocene)}

The interval with the concurrent occurrence of Ceratolithus primus and Discoaster quinquarmus.

This zone is equivalent to the Ceratolithus primus Subzone of Bukry (1973d) and to the D. quinqueramus Zone of Gartner (1974). 
TABLE 3A

Checklist of Calcareous Nannofossils Recovered at Site 286

\begin{tabular}{|c|c|c|c|c|c|c|c|c|c|c|c|}
\hline $\begin{array}{c}\text { Species } \\
\text { Sample } \\
\text { (Interval } \\
\text { in } \mathrm{cm})\end{array}$ & 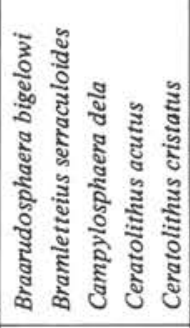 & 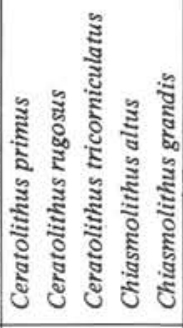 & 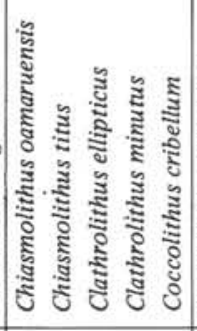 & 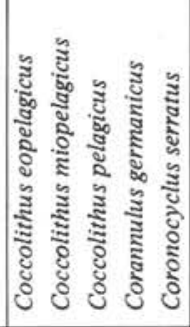 & 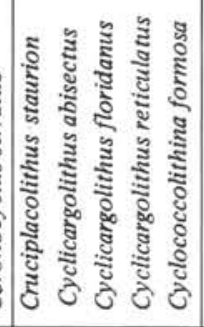 & 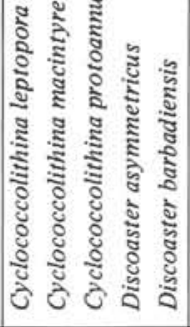 & 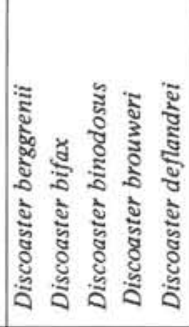 & 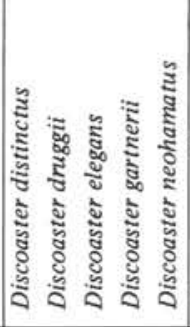 & 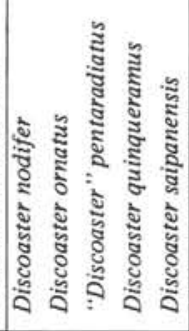 & 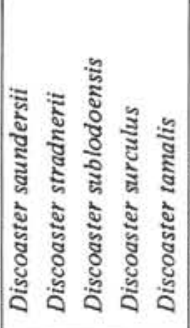 & 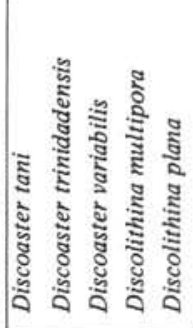 \\
\hline $\begin{array}{l}1-1,110-111 \\
1-2,10-11 \\
1-3,140-141 \\
1-4,105-106 \\
1-5,31-32\end{array}$ & $\begin{array}{l}+ \\
+ \\
+ \\
+ \\
+\end{array}$ & & & + & + & $\begin{array}{r}+ \\
+ \\
+ \\
+ \\
+ \\
\end{array}$ & + & & + & & + \\
\hline $\begin{array}{l}1, \mathrm{CC} \\
2-1,129-130 \\
2-2,55-56 \\
2-3,30-31 \\
2-3,80-81\end{array}$ & $\begin{array}{l}+ \\
+ \\
+ \\
+ \\
+\end{array}$ & & & + & $\begin{array}{r}+ \\
+ \\
+\end{array}$ & $\begin{array}{l}++ \\
++ \\
+ \\
+ \\
+ \\
+\end{array}$ & + & & + & & \\
\hline $\begin{array}{l}2-4,32-33 \\
2-4,82-83 \\
2-4,105-107 \\
2-5,125-126 \\
2-6,30-31\end{array}$ & $+{ }_{+}^{+}$ & + & & + & + & $\begin{array}{r}+ \\
+ \\
+ \\
+ \\
+ \\
+\end{array}$ & $\begin{array}{l}+ \\
+ \\
+\end{array}$ & & $\begin{array}{l}+ \\
+ \\
+\end{array}$ & $\begin{array}{l}++ \\
+\end{array}$ & + \\
\hline $\begin{array}{l}2, \mathrm{CC} \\
3-1 \\
3-2,30-31 \\
3-3,30-31 \\
3-4,95-96\end{array}$ & + & & & + & & + & + & & & . & \\
\hline $\begin{array}{l}3-5,2 \\
3-5,120-121 \\
3, \mathrm{CC} \\
4-1,120-121 \\
4, \mathrm{CC}\end{array}$ & $\begin{array}{l}+ \\
+ \\
+\end{array}$ & $\begin{array}{r}++ \\
+++\end{array}$ & & $\begin{array}{l}+ \\
+ \\
+\end{array}$ & + & $\begin{array}{l}+ \\
+ \\
+ \\
+ \\
+ \\
+ \\
+\end{array} \quad+$ & $\begin{array}{l}+ \\
+ \\
+ \\
+ \\
+\end{array}$ & + & $\begin{array}{l}+ \\
+ \\
+ \\
+\end{array}$ & $\begin{array}{l}+ \\
++ \\
+ \\
+\end{array}$ & + \\
\hline $\begin{array}{l}5-1,140-141 \\
5-2,30-31 \\
5-3,30-31 \\
5-4,13-14 \\
5-5,30-31\end{array}$ & & & + & & + & & cf. & cf. & & & + \\
\hline $\begin{array}{l}5-5,120-121 \\
5, \mathrm{CC} \\
6-1 \\
6-2,15-16 \\
6-3,30-31\end{array}$ & & & + & $+\quad+$ & $\begin{array}{r}+ \\
++ \\
+ \\
+ \\
+ \\
+\end{array}$ & & + & & & $\begin{array}{l}+ \\
+\end{array}$ & + \\
\hline $\begin{array}{l}6-4,30-31 \\
6-4,121-122 \\
6-5,35-36 \\
6, \mathrm{CC} \\
7-1,120-121\end{array}$ & & & & $\begin{array}{l}+ \\
+ \\
+ \\
+ \\
+\quad+ \\
\end{array}$ & $\begin{array}{l}++ \\
+ \\
++ \\
++ \\
+ \\
\end{array}$ & & $\begin{array}{l}+ \\
+\end{array}$ & & & $\begin{array}{l}+ \\
+ \\
+\end{array}$ & + \\
\hline $\begin{array}{l}7-2,115-116 \\
7-3,35-36\end{array}$ & & & & $\begin{array}{l}+ \\
++\end{array}$ & $\begin{array}{r}+ \\
++\end{array}$ & & $\begin{array}{l}+ \\
+\end{array}$ & & $\begin{array}{l}+ \\
+ \\
+\end{array}$ & + & $\begin{array}{l}+ \\
+ \\
+\end{array}$ \\
\hline
\end{tabular}




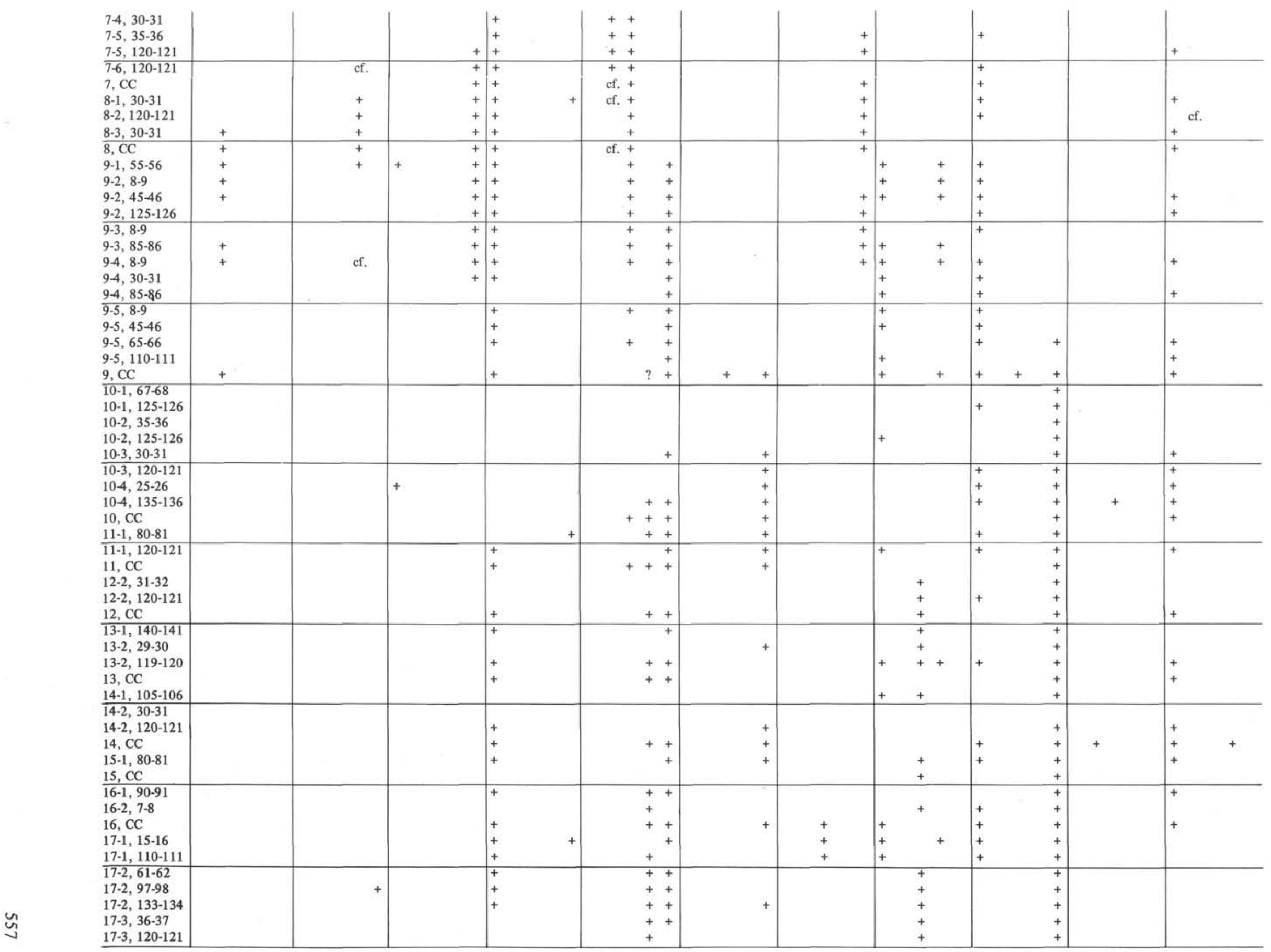




\begin{tabular}{|c|c|c|c|c|c|c|c|c|c|c|c|}
\hline $\begin{array}{l}\text { Species } \\
\text { Sample } \\
\text { (Interval } \\
\text { in } \mathrm{cm} \text { ) }\end{array}$ & 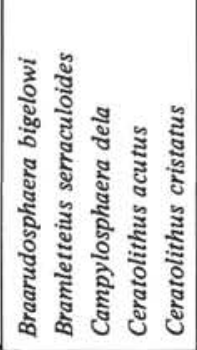 & 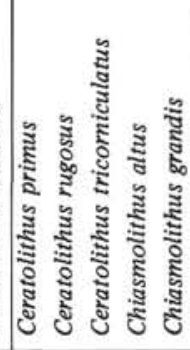 & 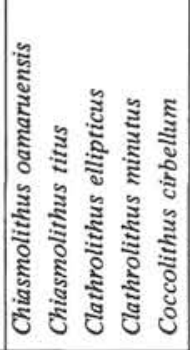 & 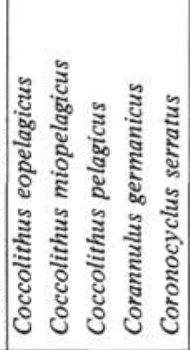 & 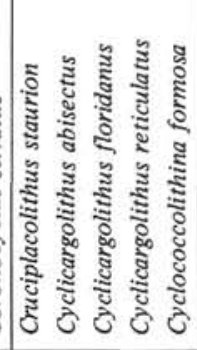 & 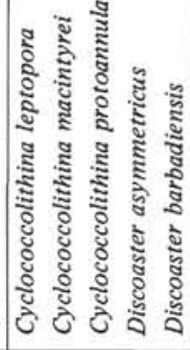 & 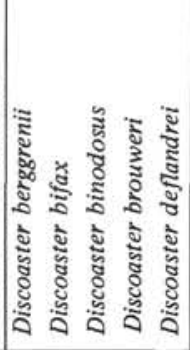 & 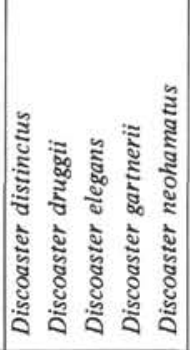 & 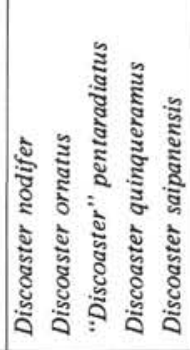 & 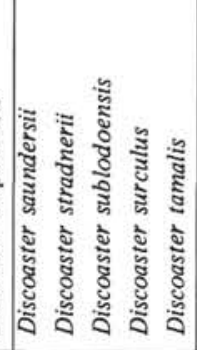 & 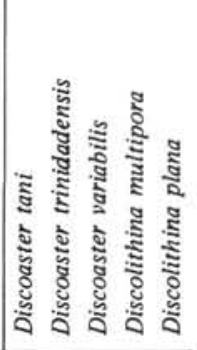 \\
\hline $\begin{array}{l}17-4,43-44 \\
17-4,106-108 \\
17-4,132-133 \\
17-5,59-60 \\
17-5,120-121\end{array}$ & $\begin{array}{l}++ \\
+\end{array}$ & $\begin{array}{l}+ \\
+ \\
+\end{array}$ & ++ & $\begin{array}{lll}+ & & \\
+ & & \\
+ & \\
+ & +\end{array}$ & $\begin{array}{r}++ \\
+++ \\
++ \\
+++ \\
+ \\
+\end{array}$ & 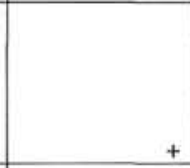 & + & $\begin{array}{r}+ \\
++ \\
++ \\
++ \\
+ \\
+\end{array}$ & $\begin{array}{l}+ \\
+ \\
+ \\
+ \\
+\end{array}$ & & + \\
\hline $\begin{array}{l}18-1,109-110 \\
18-2,112-113 \\
18, \mathrm{CC} \\
19-1,95-96 \\
19, \mathrm{CC}\end{array}$ & & + & & $\begin{array}{l}+ \\
+ \\
+\end{array}$ & $\begin{array}{c}+ \\
+ \\
+++ \\
+++ \\
+++ \\
++\end{array}$ & + & + & & $\begin{array}{lll}+ & & + \\
+ & & + \\
+ & + & + \\
+ & + & +\end{array}$ & & \\
\hline $\begin{array}{l}20-1,136-138 \\
20-2,130-131 \\
20, \mathrm{CC} \\
21-1,97-98 \\
21-2,141-142\end{array}$ & & + & & $\begin{array}{l}+ \\
+ \\
+ \\
+ \\
+ \\
\end{array}$ & $\begin{array}{rr}+ & + \\
+ \\
+ \\
\end{array}$ & $\begin{array}{l}+ \\
+ \\
+ \\
+ \\
+\end{array}$ & & & $\begin{array}{l}+ \\
+ \\
+\end{array}$ & 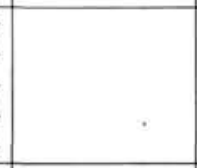 & + \\
\hline $\begin{array}{l}21, \mathrm{CC} \\
22-1,128-129 \\
22-2,64-71 \\
22-3,118-119 \\
22, \mathrm{CC} \\
\end{array}$ & + & + & & $\begin{array}{l}+ \\
+ \\
+ \\
+ \\
+\end{array}$ & $\begin{array}{r}+ \\
+ \\
++ \\
+ \\
+++ \\
\end{array}$ & $\begin{array}{r}+ \\
+ \\
+\end{array}$ & & & + & & $\begin{array}{l}+ \\
+\end{array}$ \\
\hline $\begin{array}{l}23-1,127-128 \\
23-2,27-28 \\
23-2,124-125 \\
23, \mathrm{CC} \\
24-1,131-132 \\
\end{array}$ & + & + & & + & $\begin{array}{r}++ \\
+ \\
+ \\
++ \\
+ \\
+\end{array}$ & + & & & + & & + \\
\hline $\begin{array}{l}24-2,121-123 \\
24, \mathrm{CC} \\
25-1,149-150 \\
25-2,140-141 \\
25-3,114-115 \\
\end{array}$ & $\begin{array}{l}+ \\
+\end{array}$ & $\begin{array}{l}+ \\
+ \\
+ \\
+\end{array}$ & + & $\begin{array}{l}+ \\
+ \\
+ \\
+\end{array}$ & $\begin{array}{r}++ \\
++ \\
+ \\
+ \\
++ \\
+++ \\
\end{array}$ & $\begin{array}{l}+ \\
+ \\
+ \\
+ \\
+\end{array}$ & & & $\begin{array}{l}+ \\
+ \\
+\end{array}$ & & $\begin{array}{l}+ \\
+\end{array}$ \\
\hline $\begin{array}{l}25-4,56-57 \\
25, C C \\
26-1,131-132 \\
26-2,78-80 \\
26-3,119-120\end{array}$ & + & $\begin{array}{l}+ \\
+ \\
+\end{array}$ & + & $\begin{array}{l}+ \\
+ \\
+\end{array}$ & \begin{tabular}{rr|}
+ & + \\
& + \\
& \\
+ & + \\
+ & +
\end{tabular} & $\begin{array}{l}+ \\
+\end{array}$ & & & $\begin{array}{l}+ \\
+\end{array}$ & & \\
\hline $\begin{array}{l}26-4,27-28 \\
26, \mathrm{CC} \\
27-2,36-40\end{array}$ & + & + & $\begin{array}{l}+ \\
+\end{array}$ & $\begin{array}{l}+ \\
+ \\
+ \\
+\end{array}$ & $\begin{array}{l}+++ \\
++ \\
+ \\
+ \\
+ \\
+\end{array}$ & + & & & $\begin{array}{l}+ \\
+\end{array}$ & & \\
\hline
\end{tabular}




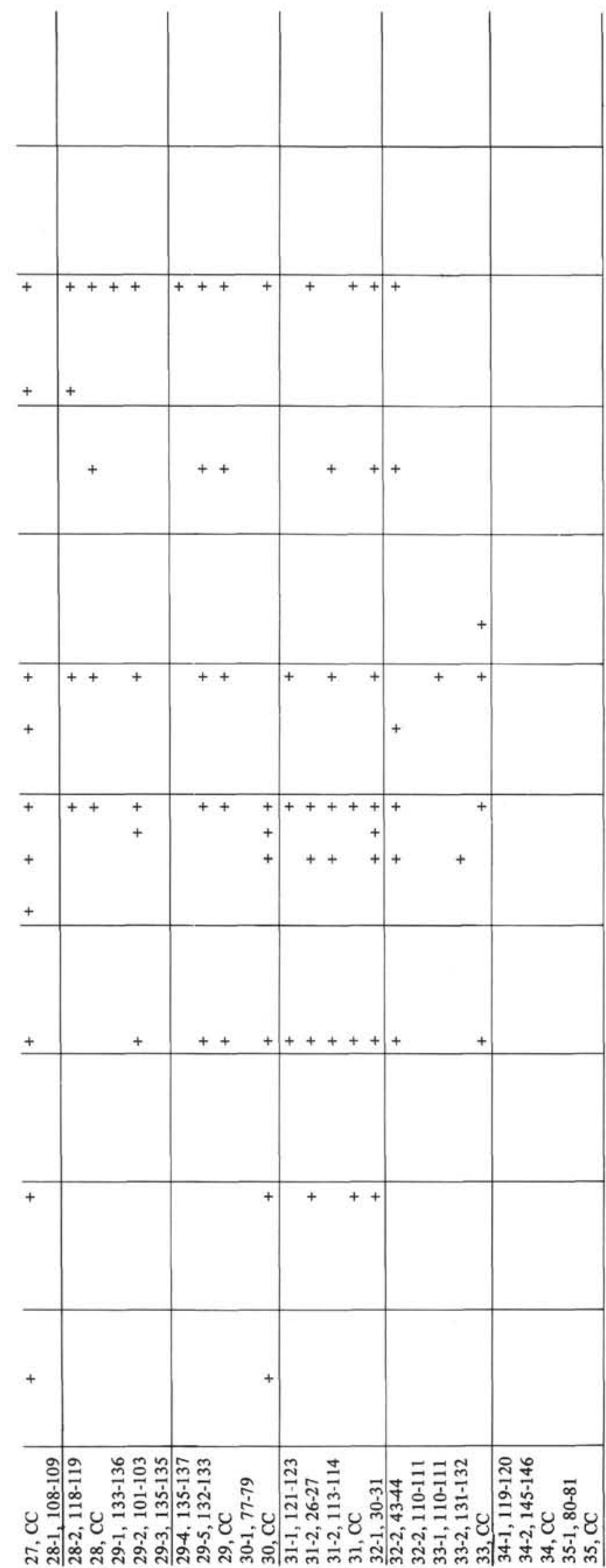

Discoaster berggrenii Zone (age: Late Miocene)

The interval from the base range of Discoaster berggrenii to the base range of Ceratolithus primus. The zone is equivalent to the $D$. berggrenii Subzone of Bukry (1973d).

\section{Discoaster neohamatus Zone (age: Late Miocene)}

The interval from the top range of Discoaster hamatus to the base range of Discoaster berggrenii. Obviously, the zone is a gap interval relying on the absence of two index species. In case of upward displacement of Discoaster hamatus, the base range of Minylitha convallis is taken to approximate the extinction of $D$. hamatus. The lower boundary of the $D$. neohamatus Zone is considered to approximate the middle upper Miocene boundary (e.g., Bukry, 1973d).

\section{Discoaster hamatus Zone (age: Middle Miocene)}

The total range of Discoaster hamatus. Following Bukry (1973d) the base range of Catinaster calyculus within this zone is used to distinguish between an upper Catinaster calyculus Subzone and a lower Helicopontosphaera kamptneri Subzone.

\section{Catinaster coalitus Zone (age: Middle Miocene)}

The short interval from the base range of Catinaster coalitus to the base range of Discoaster hamatus.

\section{Discoaster exilis Zone (age: Middle Miocene)}

The interval from the top range of Sphenolithus heteromorphus to the base range of Catinaster coalitus. The interval is a gap zone, however, it is characterized by the presence of Triquetrorhabdulus rugosus and Sphenolithus abies.

\section{Sphenolithus heteromorphus Zone (age: Early to Middle Miocene)}

The total range of Sphenolithus heteromorphus.

The zone correlates with the $S$. heteromorphus Zone of Gartner (1974). Bukry (1973d) uses the end acme horizon of Discoaster deflandrei to subdivide an interval equivalent to the $S$. heteromorphus Zone into two zones. This practice is followed here, but only to differentiate between a lower an an upper part of the zone.

\section{Sphenolithus belemnos Zone (age: Early Miocene)}

The interval from the base range of Sphenolithus belemnos to the base range of Sphenolithus heteromorphus. The zone corresponds roughly to the total range of the nominate species.

Triquetrorhabdulus carinatus Zone (age: OligoceneMiocene)

The interval from the top range of Sphenolithus ciperoensis to the base range of Sphenolithus belemnos. The zone is equivalent to the $T$. carinatus Zone of Bukry (1973d). Criteria for subdividing this zone into three subzones are given in Bukry (1973d) and have been used here. The Oligocene/Miocene boundary lies within this zone. 
TABLE 3B

Checklist of Calcareous Nannofossils Recovered at Site 268

\begin{tabular}{|c|c|c|c|c|c|c|c|c|c|c|c|}
\hline $\begin{array}{c}\text { Species } \\
\text { Sample } \\
\text { (Interval } \\
\text { in } \mathrm{cm} \text { ) }\end{array}$ & 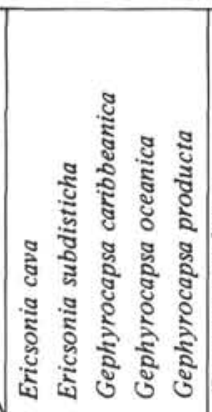 & 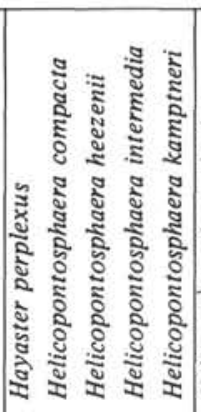 & 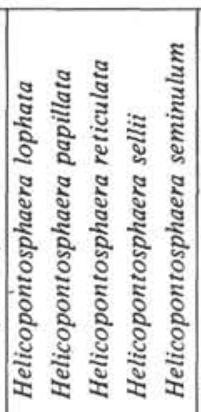 & 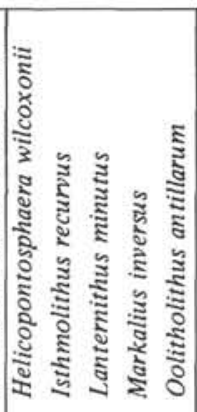 & 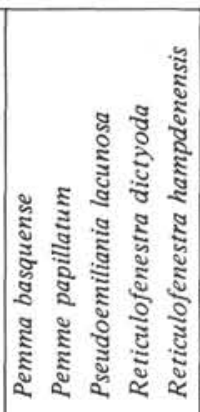 & 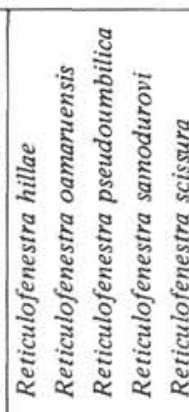 & 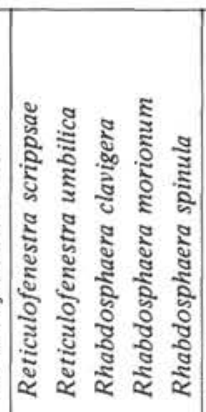 & 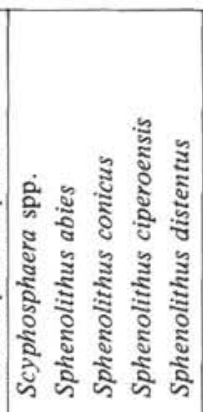 & 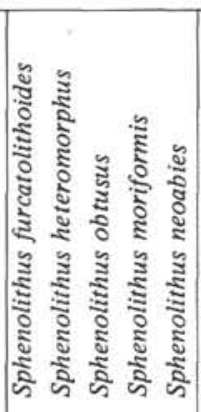 & 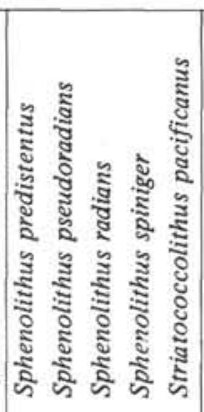 & 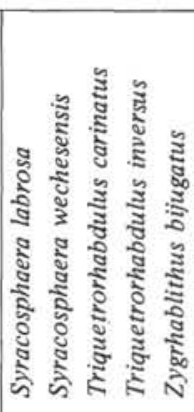 \\
\hline $\begin{array}{l}1-1,110-111 \\
1-2,10-11 \\
1-3,140-141 \\
1-4,105-106 \\
1-5,31-32\end{array}$ & $\begin{array}{c}+++ \\
++ \\
+ \\
+ \\
+\end{array}$ & $\begin{array}{l}+ \\
+ \\
+ \\
+\end{array}$ & $\begin{array}{l}+ \\
+ \\
\text { cf. } \\
+ \\
+\end{array}$ & & & + & + & + & & & \\
\hline $\begin{array}{l}1, \mathrm{CC} \\
2-1,129-130 \\
2-2,55-56 \\
2-3,30-31 \\
2-3,80-81\end{array}$ & $\begin{array}{l}+++ \\
++ \\
++ \\
+ \\
+\end{array}$ & + & + & & $\begin{array}{l}+ \\
+ \\
+ \\
+ \\
+\end{array}$ & & + & $\begin{array}{ll}+ & \\
+ & \\
+ & +\end{array}$ & & & \\
\hline $\begin{array}{l}2-4,32-33 \\
2-4,82-83 \\
1-4,105-107 \\
2-5,125-126 \\
2-6,30-31\end{array}$ & $\begin{array}{l}++ \\
+ \\
+\end{array}$ & $\begin{array}{l}+ \\
+ \\
+ \\
+\end{array}$ & $\begin{array}{l}+ \\
+\end{array}$ & & $\begin{array}{l}+ \\
+ \\
+ \\
+ \\
+\end{array}$ & $\begin{array}{l}+ \\
+\end{array}$ & $\begin{array}{l}+ \\
+\end{array}$ & + & + & & + \\
\hline $\begin{array}{l}2, \mathrm{CC} \\
3-1 \\
3-2,30-31 \\
3-3,30-31 \\
3-4,95-96\end{array}$ & + & & & & + & & & & & & \\
\hline $\begin{array}{l}3-5,2 \\
3-5,120-121 \\
3, \mathrm{CC} \\
4-1,120-121 \\
4, \mathrm{CC}\end{array}$ & & $\begin{array}{l}+ \\
+ \\
+\end{array}$ & + & + & + & $\begin{array}{l}+ \\
+ \\
+\end{array}$ & cf. & $\begin{array}{l}+ \\
++\end{array}$ & + & & \\
\hline $\begin{array}{l}5-1,140-141 \\
5-2,30-31 \\
5-3,30-31 \\
5-4,13-14 \\
5-5,30-31\end{array}$ & & & & & & + & & & & & \\
\hline $\begin{array}{l}5-5,120-121 \\
5, \mathrm{CC} \\
6-1 \\
6-2,15-16 \\
6-3,30-31\end{array}$ & & + & & & & + & & $\begin{array}{l} \\
++ \\
++ \\
+\end{array}$ & $\begin{array}{l}+ \\
+ \\
+ \\
+\end{array}$ & $\begin{array}{l}+ \\
+\end{array}$ & $\begin{array}{l}+ \\
+ \\
+ \\
\end{array}$ \\
\hline $\begin{array}{l}6-4,30-31 \\
6-4,121-122 \\
6-5,35-36 \\
6, C C \\
7-1,120-121\end{array}$ & & . & & & & $\begin{array}{l}+ \\
+ \\
+ \\
+ \\
+\end{array}$ & & $\begin{array}{r}+ \\
+ \\
+ \\
+ \\
+ \\
+\end{array}$ & $\begin{array}{l}+ \\
+ \\
+ \\
+\end{array}$ & + & $\begin{array}{l}+ \\
+ \\
+ \\
+\end{array}$ \\
\hline $\begin{array}{l}7-2,115-116 \\
7-3,35-36 \\
7-4,30-31\end{array}$ & & + & & & & $\begin{array}{l}+ \\
+ \\
+\end{array}$ & + & $\begin{array}{l}+ \\
+ \\
+\end{array}$ & $\begin{array}{l}+ \\
+ \\
+\end{array}$ & $\begin{array}{ll}+ & \\
+ \\
+\end{array}$ & \\
\hline
\end{tabular}




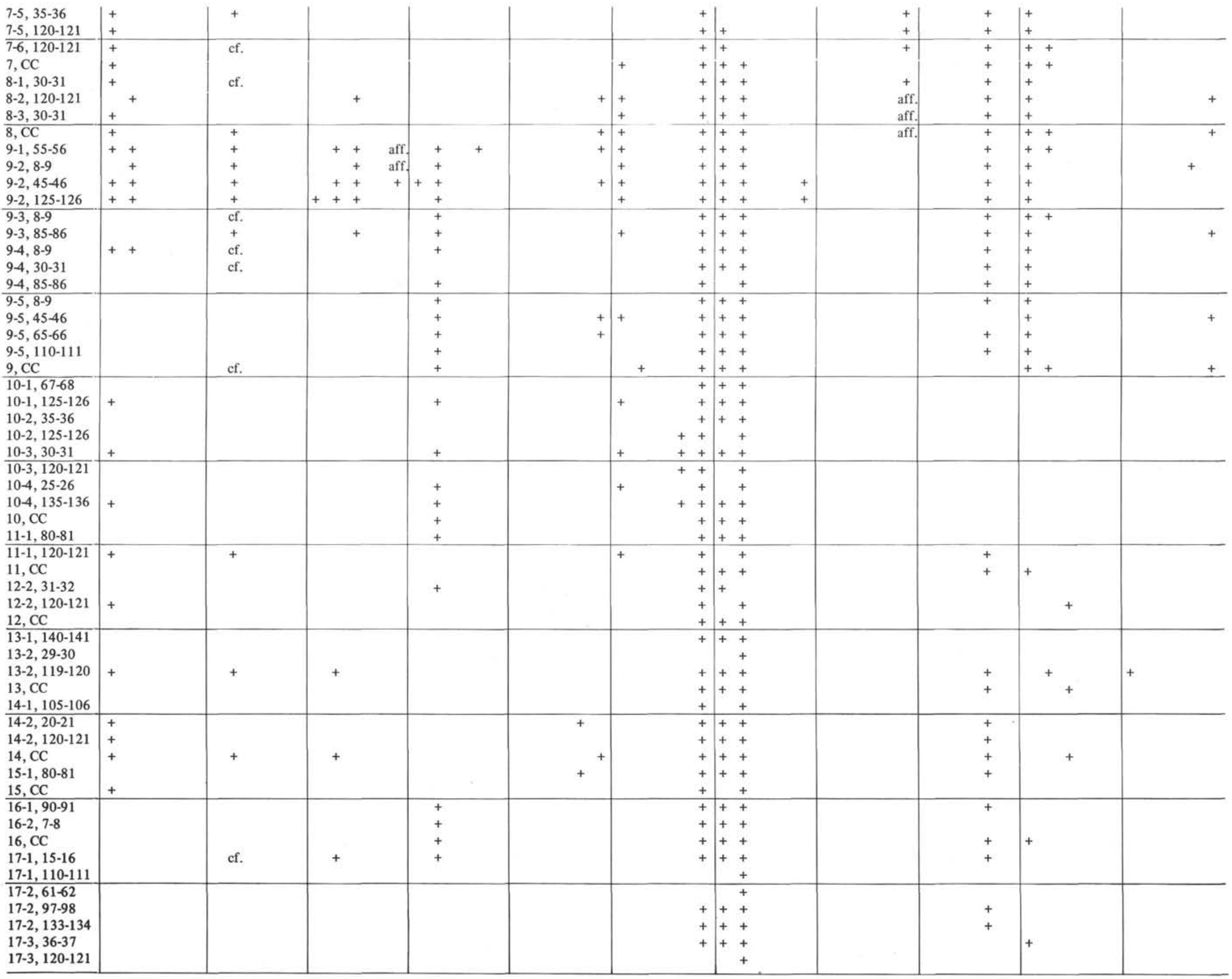




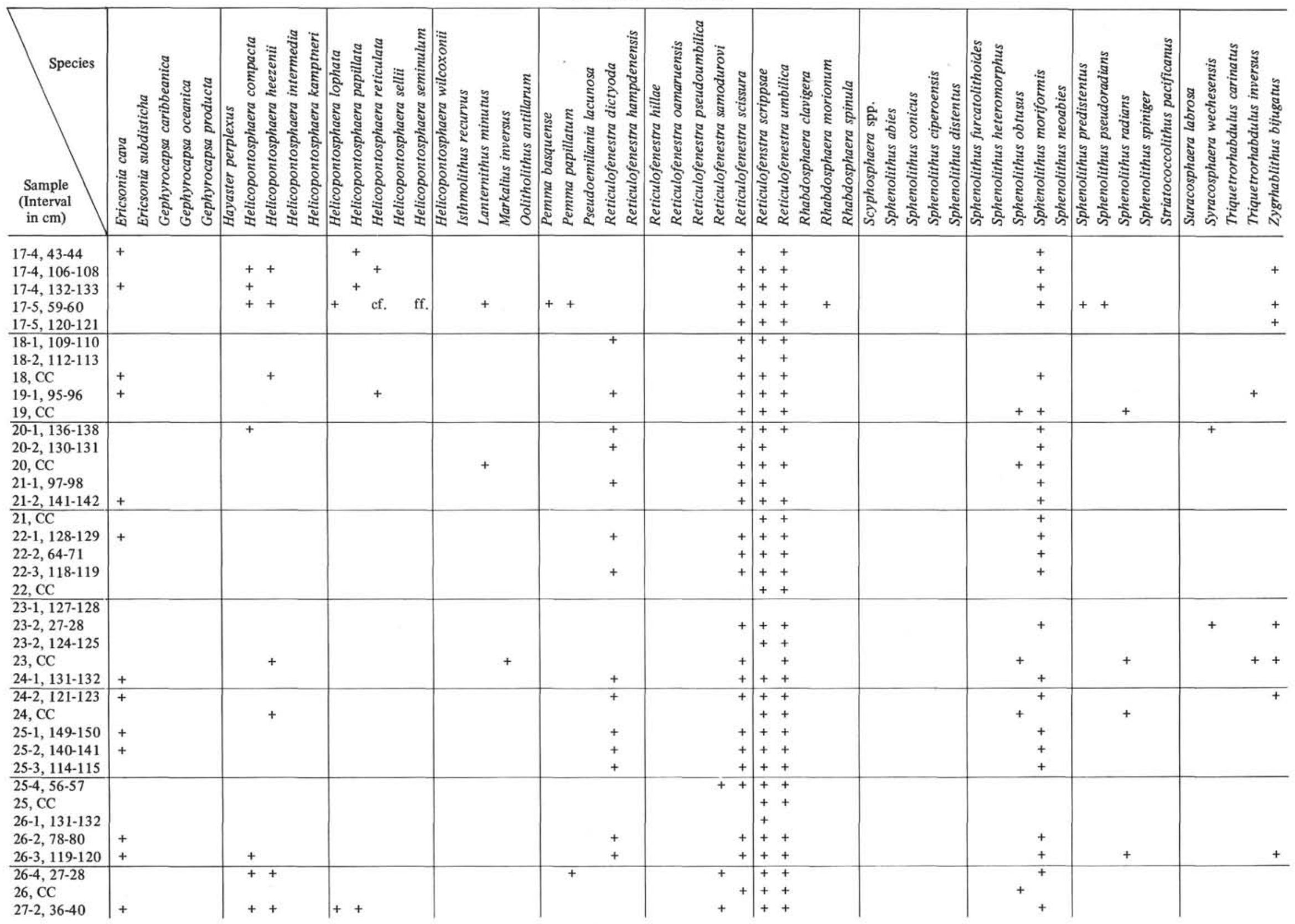




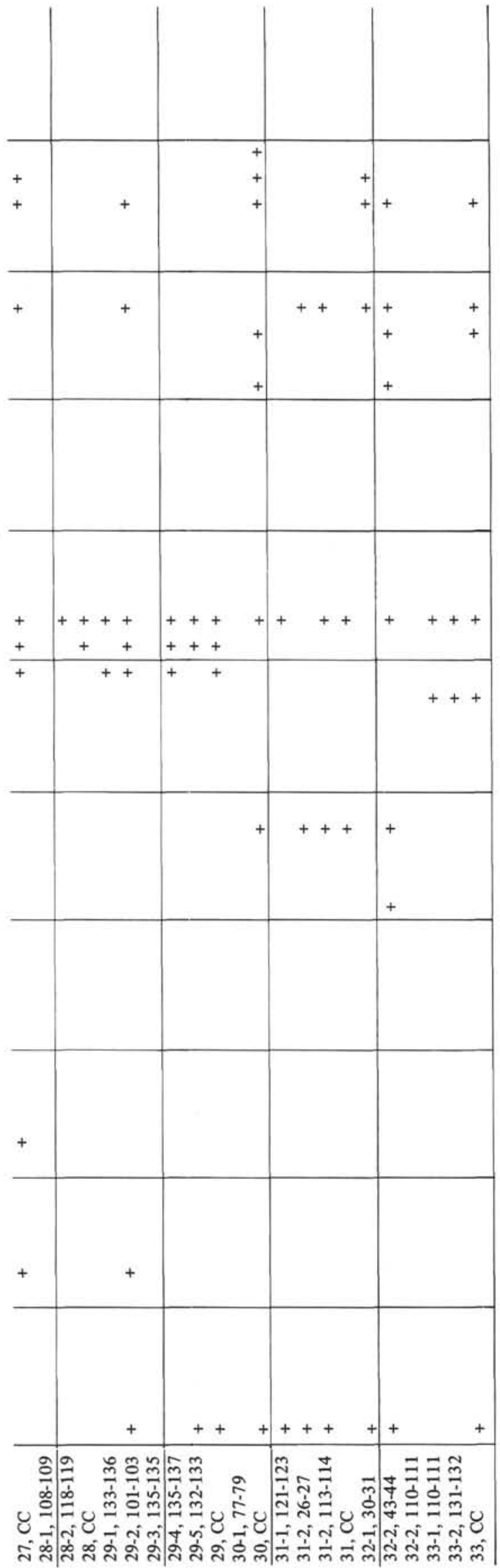

Sphenolithus ciperoensis Zone (age: Late Oligocene)

The total range of the nominate species.

Sphenolithus distentus Zone (age: Late Oligocene)

The interval from the evolutionary base of Sphenolithus distentus (phyletic emergence from its ancestor Sphenolithus predistentus to the evolutionary base of Sphenolithus ciperoensis (phyletic emergence from distentus). The zone correlates with the $S$. distentus of Bukry (1973d).

\section{Sphenolithus predistentus Zone (age: Early Oligocene)}

The interval from the top range of Reticulofenestra umbilica or its late sibling $R$. hillae to the evolutionary base of Sphenolithus distentus.

\section{Reticulofenestra hillae Zone (age: Early Oligocene)}

The interval from the top range of Cyclococcolithina formosa to the top range of Reticulofenestra hillae or $R$. umbilica.

\section{Cyclococcolithina formosa Zone (age: Early Oligocene)}

The interval from the top range of Discoaster barbadiensis or D. saipanensis to the range of Cyclococcolithina formosa.

\section{Discoaster barbadiensis Zone (age: Late Eocene)}

The interval from the top range of Chiasmolithus grandis to the top range of Discoaster barbadiensis or $D$. saipanensis.

The top range of Cyclicargolithus reticulatus is within this zone. The event proved to be useful in the biostratigraphy of the southern margin of Australia. On this evidence, a differentiation between a lower and upper D. barbadiensis Zone is achieved (e.g., Site 286).

This zone correlates with the combined Chiasmolithus oamaruensis and Isthmolithus recurvus zones usually recognized in extratropical near-shore facies, e.g., southern margin of Australia.

The Eocene/Oligocene boundary is tentatively placed at the top of the D. barbadiensis Zone.

\section{Discoaster saipanensis Zone (age: Middle Eocene)}

The interval from the top range of Chiasmolithus solitus to the top range of Chiasmolithus grandis.

The top range of $C$. grandis is taken as the middle/upper Eocene boundary.

\section{Cyclicargolithus reticulatus Zone (age: Middle Eocene)}

The interval from the base range of Cyclicargolithus reticulatus to the top range of Chiasmolithus solitus.

\section{Reticulofenestra umbilica Zone (age: Middle Eocene)}

The interval from the base range of Reticulofenestra umbilica to the base range of Cyclicargolithus reticulatus.

\section{Chiasmolithus gigas Zone (age: Middle Eocene)}

The interval from the base range of Chiasmolithus gigas to the base range of Reticulofenestra umbilica. This zone is equivalent to the combined $C$. gigas and Coccolithus staurion subzones of Bukry (1973d). 
TABLE 4

Checklist of Calcareous Nannofossils Recovered at Site 287

\begin{tabular}{|c|c|c|c|c|c|c|c|c|c|c|}
\hline $\begin{array}{c}\text { Sample } \\
\text { (Interval } \\
\text { in cm) }\end{array}$ & 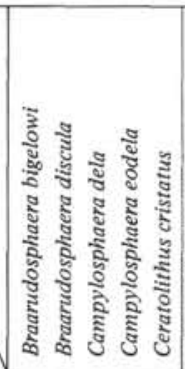 & 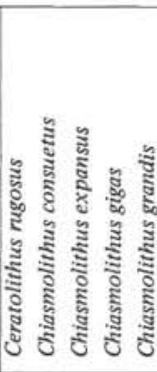 & 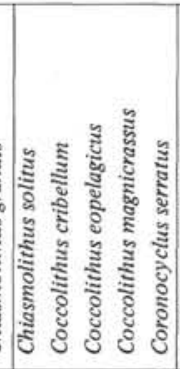 & 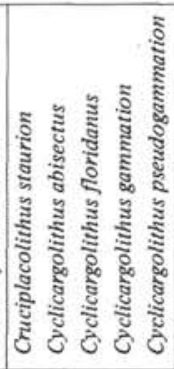 & 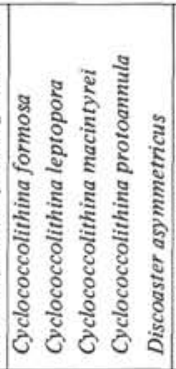 & 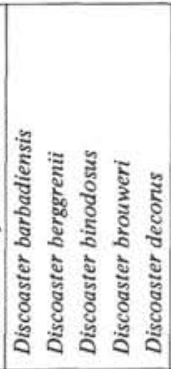 & 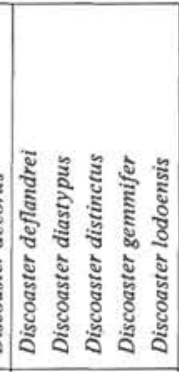 & 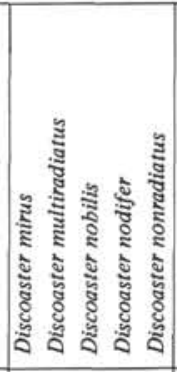 & 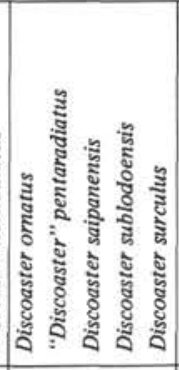 & 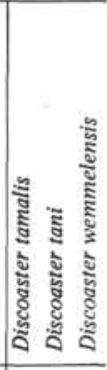 \\
\hline $\begin{array}{l}8-1,10-11 \\
8-1,120-121 \\
10-1,120-121 \\
10-2,4-5\end{array}$ & VIDIDIIIID & 11111 & & & XII & & & & & DIDI) \\
\hline $\begin{array}{l}10-2,70-71 \\
10-2,120-121 \\
10-3,8-9 \\
10-3,120-121 \\
10-4,30-31 \\
\end{array}$ & & & $\begin{aligned} &+ \\
&++ \\
&++ \\
&+ \\
&++\end{aligned}$ & $\begin{array}{l}++ \\
++ \\
++ \\
++ \\
++ \\
\end{array}$ & & & $\begin{array}{l}+ \\
+\end{array}$ & & & \\
\hline $\begin{array}{l}10-4,120-121 \\
10, \mathrm{CC} \\
11-0 \\
11-0 \\
11-1,30-31\end{array}$ & + & $\begin{array}{r}++ \\
++\end{array}$ & $\begin{array}{rrr} & + & + \\
& + & + \\
& + & + \\
+ & + & + \\
+ & + & +\end{array}$ & $\begin{array}{l}++ \\
++ \\
++\end{array}$ & $\begin{array}{l}+ \\
+ \\
+\end{array}$ & $\begin{array}{l}+ \\
+\end{array}$ & $\begin{array}{ll}+ & \\
+ \\
+ \\
+ \\
\text { F } & \\
& +\end{array}$ & + & & $\begin{array}{l}+ \\
+\end{array}$ \\
\hline $\begin{array}{l}11-1,120-121 \\
11-2,30-31 \\
11-2,120-121 \\
11-3,30-31 \\
11-3,120-121\end{array}$ & & $\begin{aligned} &++ \\
&++ \\
&++ \\
&++ \\
&++\end{aligned}$ & + & $\begin{array}{ll}+ & + \\
+ & + \\
& + \\
+ & +\end{array}$ & $\begin{array}{l}+ \\
+ \\
+ \\
+ \\
+ \\
+\end{array}$ & $\begin{array}{l}+ \\
+ \\
+ \\
+ \\
+ \\
+\end{array}$ & $\begin{array}{l}\text { ef. } \\
+\end{array}$ & + & $\begin{array}{r}+ \\
+ \\
+ \\
+ \\
+\end{array}$ & $\begin{array}{l}+ \\
+ \\
+ \\
+\end{array}$ \\
\hline $\begin{array}{l}11-4,30-31 \\
11-4,109-110 \\
11-5,30-31 \\
11-5,118-119 \\
11-6,1-3\end{array}$ & $\begin{array}{r}+ \\
+ \\
+ \\
+\end{array}$ & $\begin{array}{r}+ \\
+ \\
+ \\
+ \\
+ \\
+ \\
+\end{array}$ & $\begin{array}{l}+ \\
+ \\
+ \\
+\end{array}$ & $\begin{array}{l}+ \\
+ \\
+ \\
+\end{array}$ & $\begin{array}{l}+ \\
+ \\
+ \\
+ \\
+ \\
+\end{array}$ & $\begin{array}{l}+ \\
+ \\
+ \\
+ \\
+ \\
+ \\
+\end{array}$ & $\begin{array}{lll}\text { aff. } & & + \\
& + & + \\
& & + \\
+ & & \text { cf. } \\
+ & & +\end{array}$ & $\begin{array}{l}+ \\
+\end{array}$ & $\begin{array}{l}+ \\
+ \\
+ \\
+\end{array}$ & $\begin{array}{l}+ \\
+ \\
+ \\
+ \\
+\end{array}$ \\
\hline $\begin{array}{l}11, \mathrm{CC} \\
12-1,100-101 \\
12-2,30-31 \\
12-2,120-121 \\
12-3,30-31\end{array}$ & + & $\begin{array}{r}+ \\
+\quad+ \\
+ \\
+ \\
+ \\
+\quad+\end{array}$ & $\begin{array}{ll}+ & + \\
+ & \\
+ & \\
+ & +\end{array}$ & $\begin{array}{l}+ \\
+ \\
+ \\
+ \\
+\end{array}$ & $\begin{array}{l}+ \\
+ \\
+ \\
+ \\
+ \\
+\end{array}$ & $\begin{array}{l}+ \\
+ \\
+ \\
+ \\
+ \\
+ \\
+\end{array}$ & $\begin{array}{l}\text { cf. } \\
+ \\
\text { cf. } \\
+\end{array}$ & $\begin{array}{l}+ \\
+\end{array}$ & $\begin{array}{l}+ \\
+ \\
+ \\
+\end{array}$ & $\begin{array}{l}+ \\
+ \\
+\end{array}$ \\
\hline $\begin{array}{l}12-3,120-121 \\
12-4,30-31 \\
12-4,120-121 \\
12-5,30-31 \\
12-5,120-121\end{array}$ & $\begin{array}{l}+ \\
+\end{array}$ & $\begin{array}{r}\text { cf. }+ \\
\text { cf. }+ \\
+ \\
\text { cf. }+ \\
+\end{array}$ & $\begin{array}{l}+ \text { ef. } \\
+ \\
+ \\
+ \\
+\end{array}$ & + & $\begin{array}{l}+ \\
+ \\
+ \\
+ \\
+ \\
+ \\
+\end{array}$ & $\begin{array}{l}+ \\
+ \\
+ \\
+ \\
+ \\
+\end{array}$ & $\begin{array}{l}+ \\
+\end{array}$ & $\begin{array}{l}+ \\
+ \\
+ \\
+\end{array}$ & $\begin{array}{l}+ \\
+ \\
+ \\
+ \\
++\end{array}$ & $\begin{array}{l}+ \\
+ \\
+ \\
+ \\
+ \\
+\end{array}$ \\
\hline $\begin{array}{l}12, \mathrm{CC} \\
13-1,145-146 \\
13-2,30-31 \\
13-2,120-121 \\
13-3,30-31\end{array}$ & & $\begin{array}{r}+ \\
+ \\
+ \\
+ \\
+ \\
+\end{array}$ & $\begin{array}{ll}+ & \\
+ & + \\
+ & \\
+ & \\
+ & \end{array}$ & $\begin{array}{l}+ \\
+\end{array}$ & $\begin{array}{l}+ \\
+ \\
+ \\
+ \\
+ \\
+\end{array}$ & $\begin{array}{l}+ \\
+ \\
+ \\
+ \\
+ \\
+\end{array}$ & $\begin{array}{r}+ \\
+ \\
+ \\
+\end{array}$ & $\begin{array}{l}+ \\
+ \\
+ \\
+ \\
+\end{array}$ & 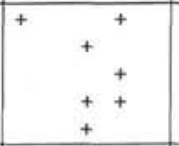 & $\begin{array}{l}+ \\
+ \\
+ \\
+\end{array}$ \\
\hline $\begin{array}{l}13-3,120-121 \\
13, \mathrm{CC} \\
14-1,100-101 \\
14-2,30-31 \\
14-2,120-121\end{array}$ & + & $\begin{array}{l}+ \\
+ \\
+ \\
+ \\
+\end{array}$ & $\begin{array}{ll}+ & + \\
+ & + \\
+ & \\
+ & + \\
+ & +\end{array}$ & + & $\begin{array}{l}+ \\
+ \\
+ \\
+ \\
+ \\
+ \\
+\end{array}$ & $\begin{array}{l}+ \\
+ \\
+ \\
+ \\
+ \\
+\end{array}$ & & $\begin{array}{l}+ \\
+\end{array}$ & $\begin{array}{r}+ \\
+ \\
+ \\
+ \\
+ \\
+ \\
+\end{array}$ & $\begin{array}{l}+ \\
++ \\
+\end{array}$ \\
\hline $\begin{array}{l}14-3,30-31 \\
14-3,120-121 \\
14, \mathrm{CC} \\
15-1,100-101 \\
15-2,30-31\end{array}$ & $\begin{array}{l}+ \\
+ \\
+\end{array}$ & $\begin{array}{l}+ \\
+ \\
+ \\
+ \\
+\end{array}$ & 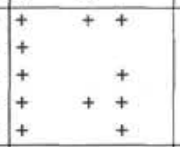 & $\begin{array}{l}+ \\
+ \\
+\end{array}$ & $\begin{array}{l}+ \\
+ \\
+ \\
+ \\
+ \\
+ \\
+\end{array}$ & $\begin{array}{l}+ \\
+ \\
+ \\
+ \\
+ \\
+\end{array}$ & + & $\begin{array}{r}+ \\
+ \\
++ \\
\end{array}$ & $\begin{array}{r}+ \\
+ \\
+ \\
+ \\
+ \\
+\end{array}$ & cf. \\
\hline $\begin{array}{l}15-2,120-121 \\
15, \mathrm{CC} \\
16-1\end{array}$ & + & $\begin{array}{l}+ \\
+ \\
+\end{array}$ & $\begin{array}{lll}+ & + \\
+ & +\end{array}$ & + & $\begin{array}{l}+ \\
+\end{array}$ & & + & $\begin{array}{l}+ \\
+ \\
+\end{array}$ & $\begin{array}{l}+ \\
+\end{array}$ & \\
\hline
\end{tabular}

Nannotetrina fulgens Zone (age: Middle Eocene)

The interval from the base range of Nannotetrina fulgens to the base range of Chiasmolithus gigas. The zone is equivalent to the Discoaster strictus Subzone of Bukry (1973d).

Discoaster sublodoensis Zone (age: Early to Middle Eocene)

The interval from the base range of Discoaster sublodoensis to the base range of Nannotetrina fulgens.
Following Bukry (1973d), this zone is subdivided into the Rhabdosphaera inflata and Discoasteroides kuepperi subzones on the initial appearance of $R$. inflata. Where recognized this event locates the middle/lower Eocene boundary.

\section{Discoaster lodoensis Zone (age: Early Eocene)}

The interval from the top of abundant Tribrachiatus orthostylus to the base range of Discoaster sublodoensis. The older event is the extinction of T. orthostylus of 
TABLE 4 - Continued

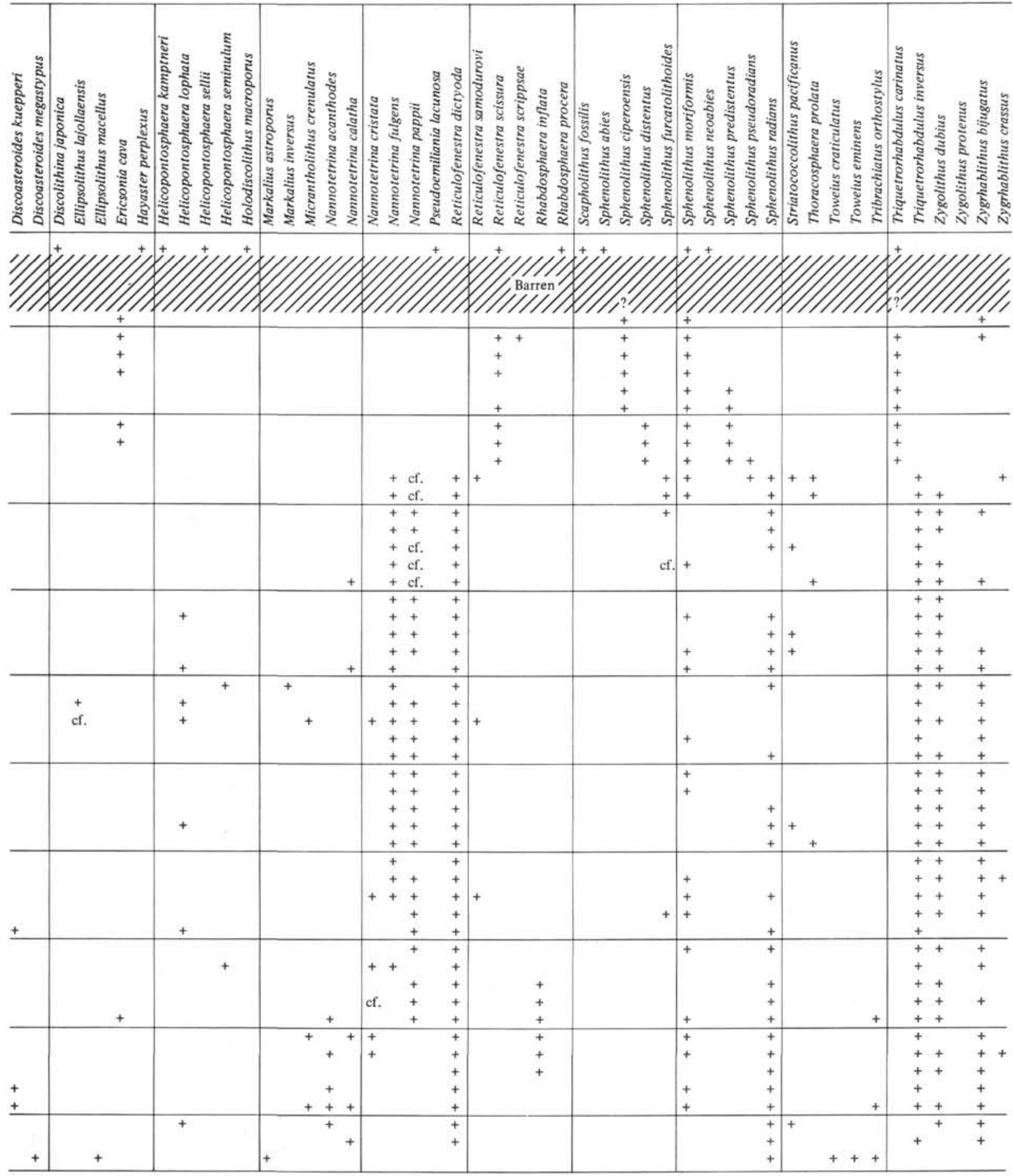

several authors, but observations support Bukry's (1973d) suggestion that the event is rather a sharp drop in abundance.

\section{Tribrachiatus orthostylus Zone (age: Early Eocene)}

The interval from the base range of Discoasterlodoensis to the top abundance of Tribrachiatus orthostylus.

\section{Discoaster diastypus Zone (age: Early Eocene)}

The interval from the base of Discoaster diastypus to the base range of Discoaster lodoensis.
The base of this zone is taken as the Eocene/Paleocene boundary.

Discoaster multiradiatus Zone (age: Late Paleocene)

The interval from the base range of Discoaster multiradiatus to the base range of Discoaster diastypus.

Discoaster nobilis Zone (age: Middle Paleocene)

The interval from the base range of Discoaster nobilis to the base range of Discoaster multiradiatus. This zone has not been identified in Leg 30 material. 
TABLE 5A

Checklist of Calcareous Nannofossils Recovered at Site 288

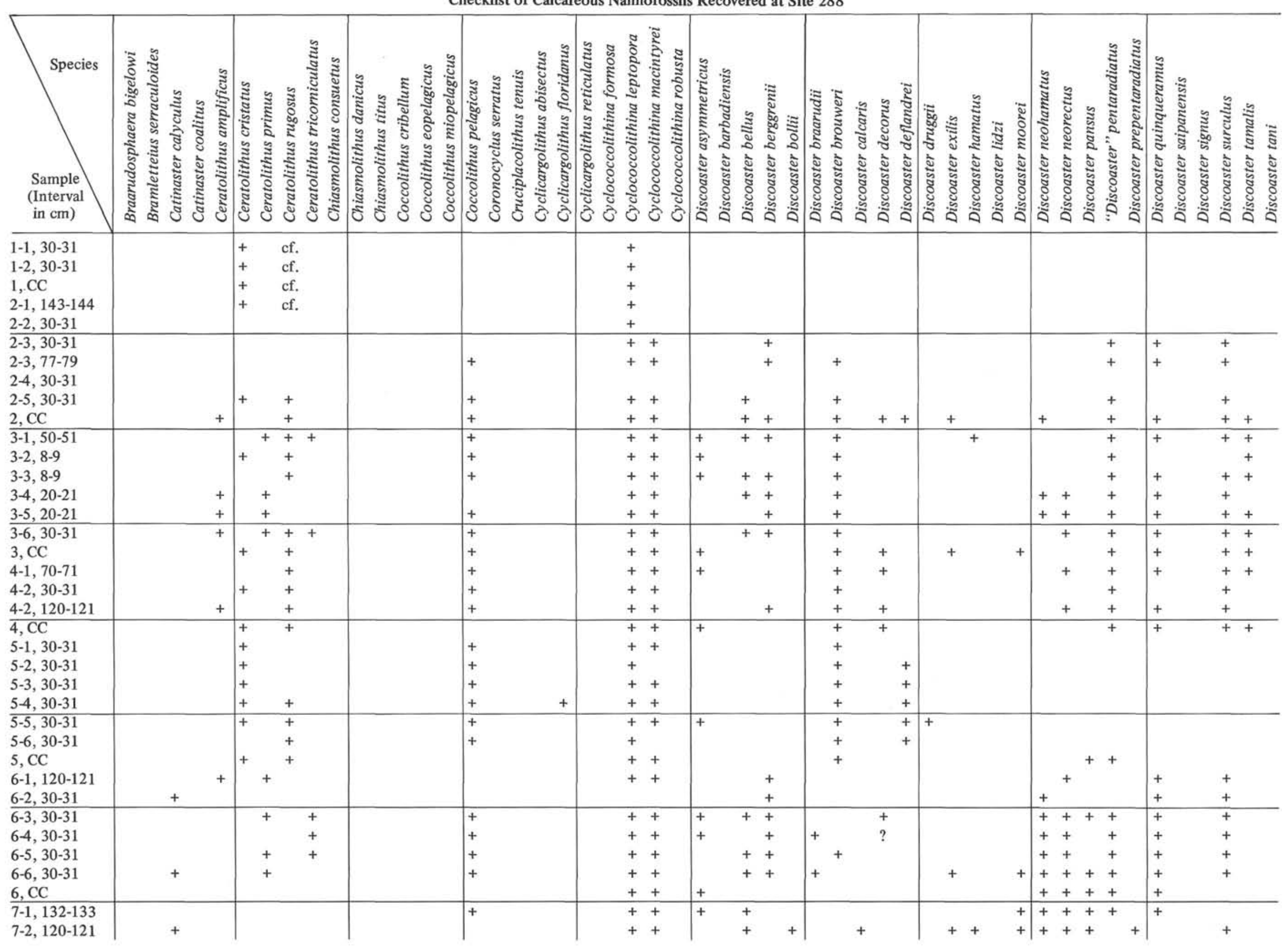




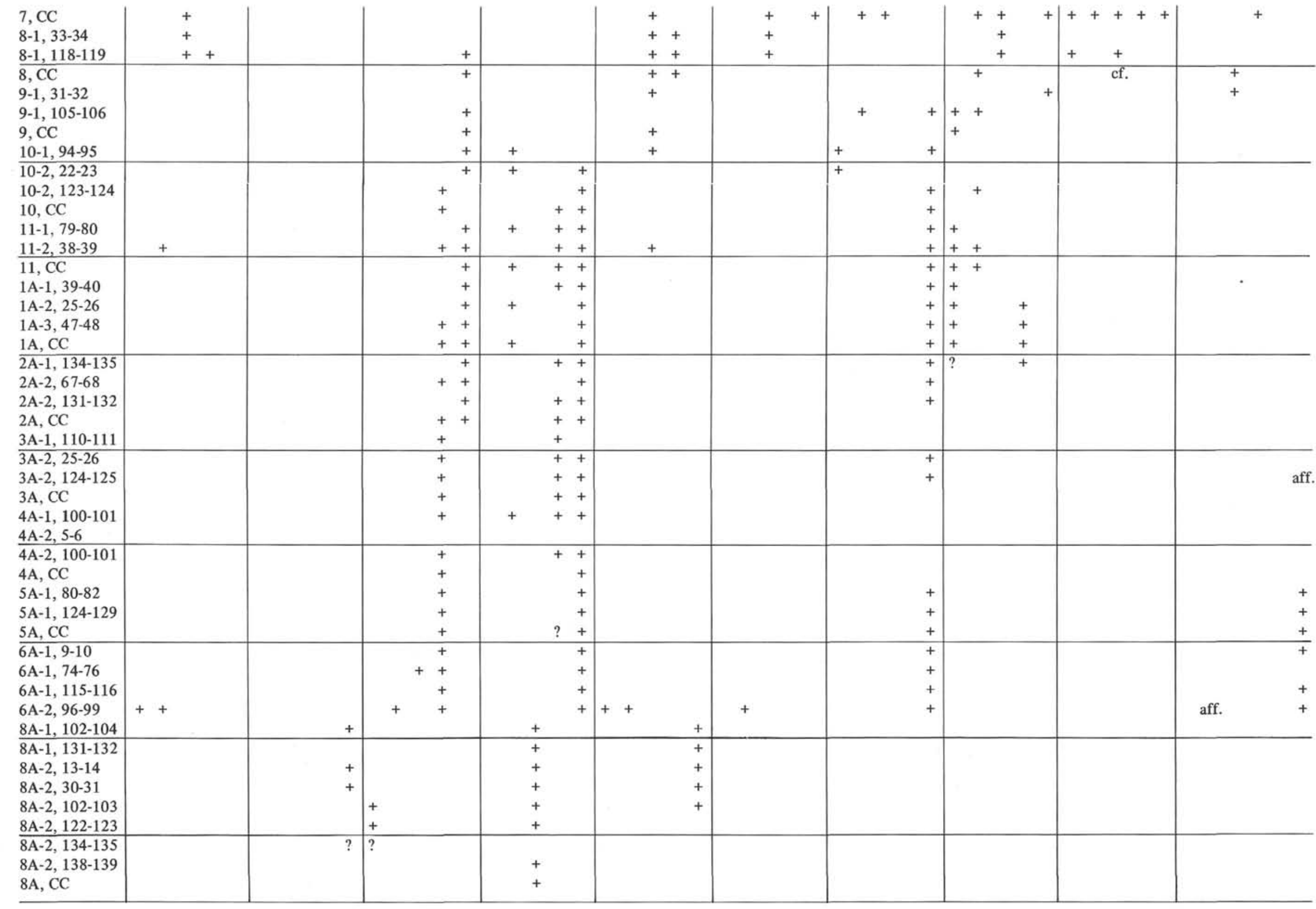


TABLE 5B

Checklist of Calcareous Nannofossils Recovered at Site 288.

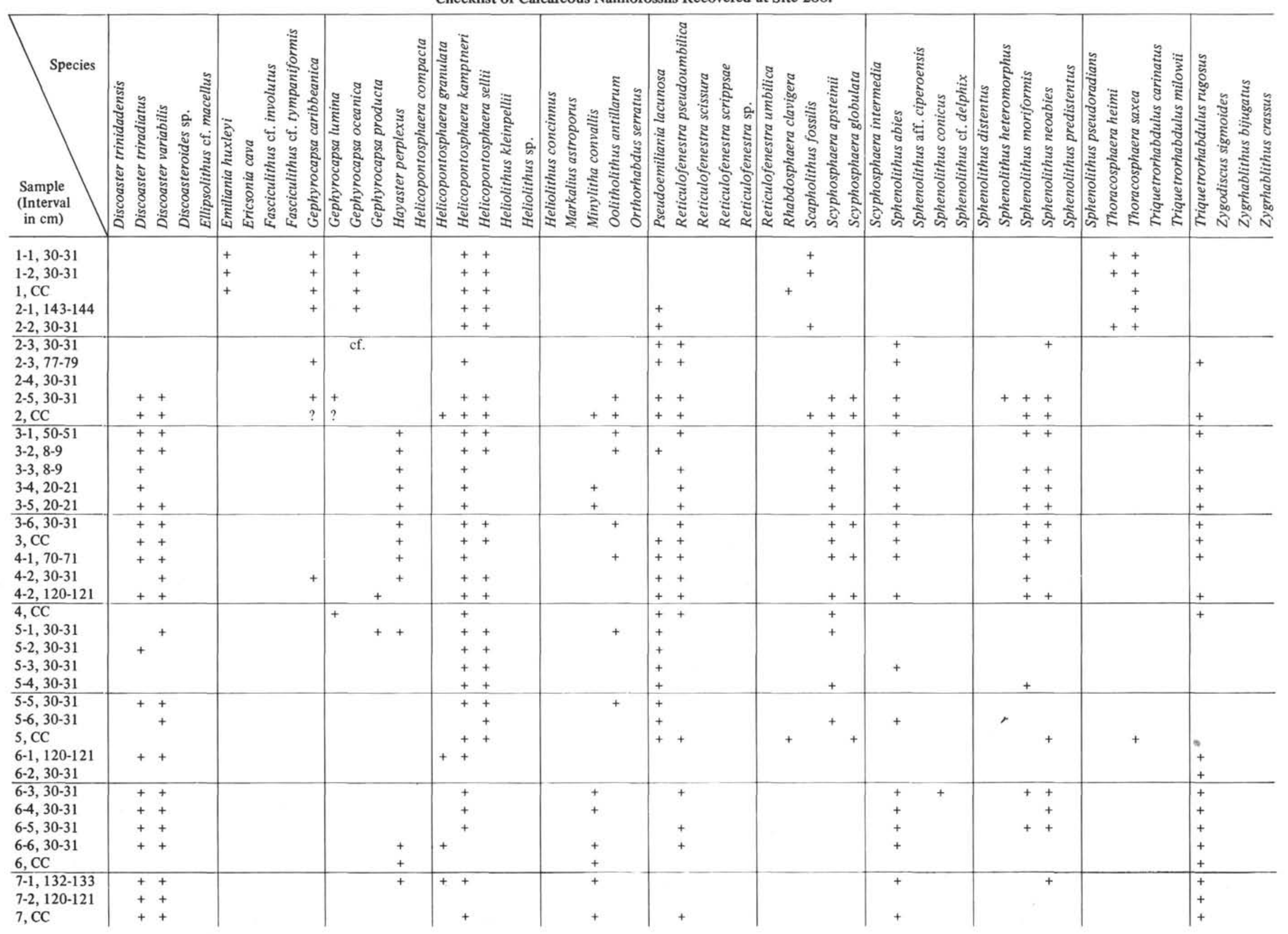




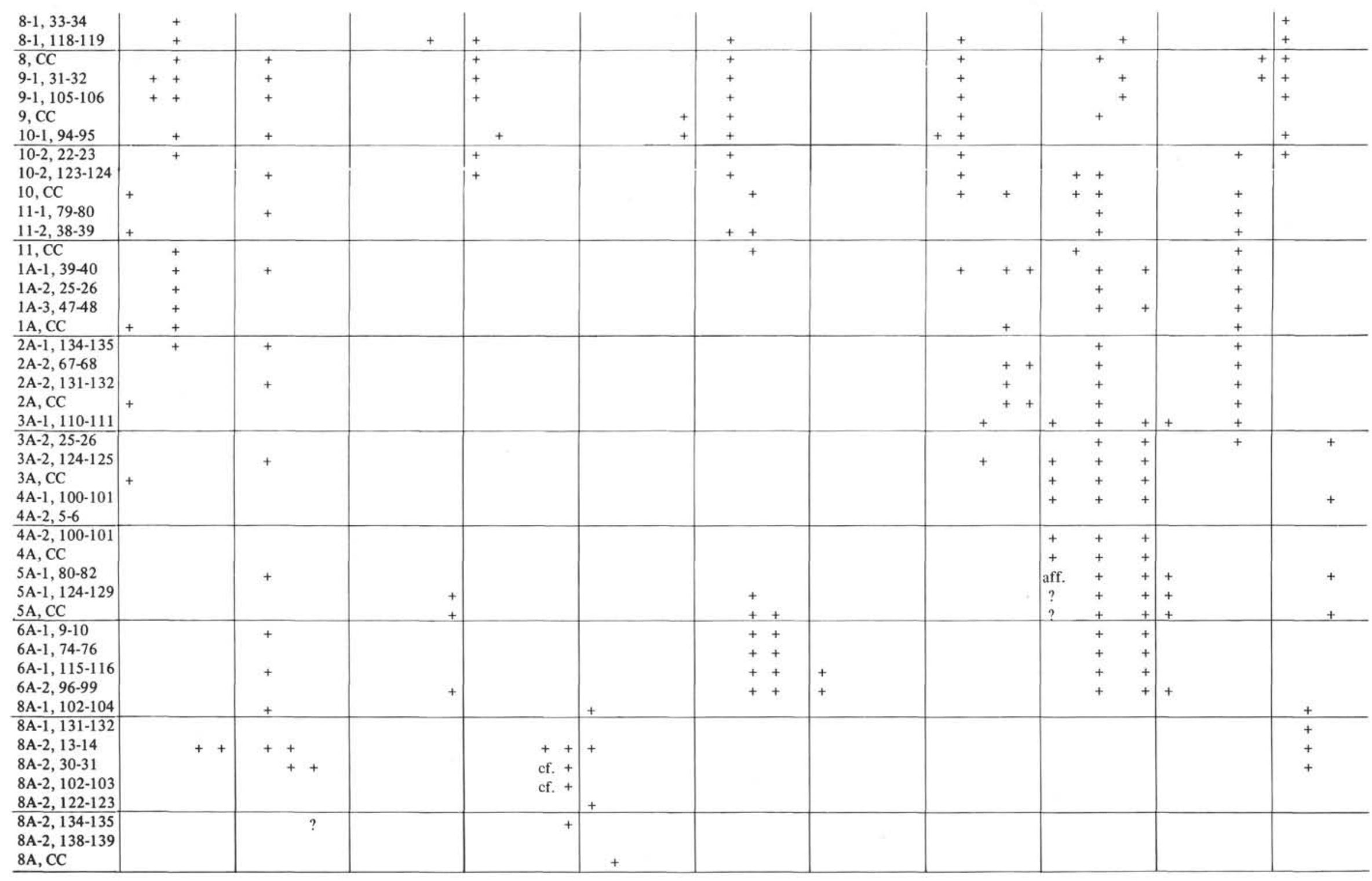




\begin{tabular}{|c|c|c|c|c|c|c|c|c|c|c|c|c|}
\hline Species & 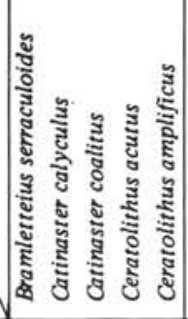 & 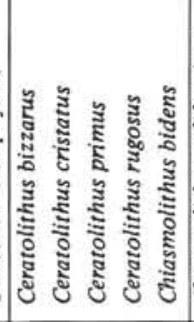 & 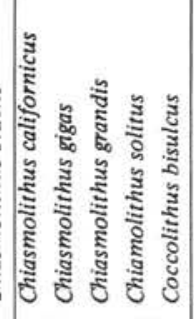 & 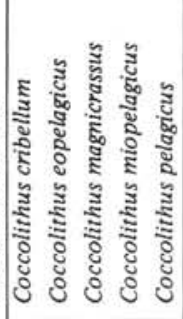 & 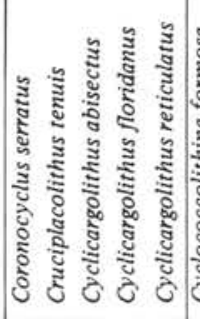 & 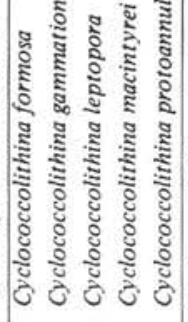 & 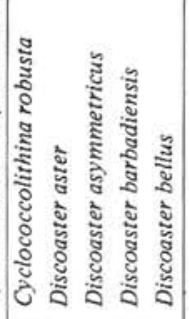 & 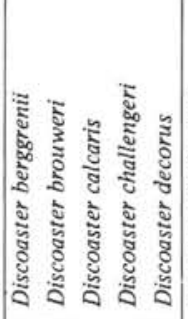 & 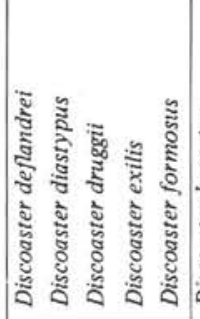 & 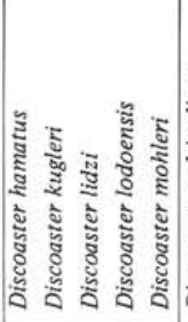 & 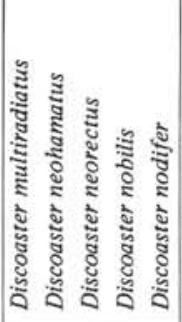 & 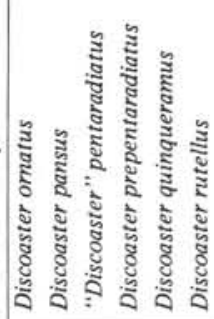 \\
\hline $\begin{array}{l}1-1,30-31 \\
1-2,30-31 \\
1-3,30-31 \\
1-4,30-31 \\
1-5,30-31\end{array}$ & & $\begin{array}{l}+ \\
+ \\
+ \\
+\end{array}$ & & & & $\begin{array}{l}+ \\
+ \\
+ \\
+ \\
+\end{array}$ & & & & & & \\
\hline $\begin{array}{l}1-6,30-31 \\
1, C C \\
2-1,30-31 \\
2-2,25-26 \\
2-3,30-31\end{array}$ & & $\begin{array}{l}+ \\
+ \\
+ \\
+\end{array}$ & & & & $\begin{array}{l}+ \\
+ \\
+ \\
+\end{array}$ & & & & & & \\
\hline $\begin{array}{l}2-4,30-31 \\
2-5,30-31 \\
2-6,30-31 \\
2-6,120-121 \\
2, \mathrm{CC}\end{array}$ & & cf. & & + & & $\begin{array}{l}+ \\
+ \\
+ \\
+ \\
+\end{array}$ & & & & & & \\
\hline $\begin{array}{l}3-1,30-31 \\
3-2,30-31 \\
3-3,30-31 \\
3-4,30-31 \\
3-5,30-31\end{array}$ & & $\begin{array}{l}+ \\
+\end{array}$ & & $\begin{array}{l}+ \\
+\end{array}$ & & $\begin{array}{l}+ \\
+ \\
+ \\
+ \\
+ \\
\end{array}$ & & & & & & \\
\hline $\begin{array}{l}3-6,30-31 \\
3, \mathrm{CC} \\
4-1,120-121 \\
4-2,30-31 \\
4-3,30-31\end{array}$ & & $\begin{array}{l}+ \\
+\end{array}$ & & & & $\begin{array}{l}+ \\
+ \\
+ \\
+\end{array}$ & & & & & & \\
\hline $\begin{array}{l}4-3,110-111 \\
4-4,30-31 \\
4-5,30-31 \\
4-6,30-31 \\
4-6,120-121\end{array}$ & & $\begin{array}{ll}+ & + \\
+ & + \\
+ & + \\
& +\end{array}$ & & $\begin{array}{l}+ \\
+ \\
\end{array}$ & & $\begin{array}{l}++ \\
++ \\
++ \\
++ \\
++\end{array}$ & & + & & & & \\
\hline $\begin{array}{l}4, C C \\
5-1,30-31 \\
5-2,30-31 \\
5-3,30-31 \\
5-4,30-31\end{array}$ & & $\begin{array}{ll}+ & \\
+ & + \\
+ & +\end{array}$ & & $\begin{array}{l}+ \\
+ \\
+ \\
+ \\
+\end{array}$ & & $\begin{array}{l}++ \\
+ \\
++ \\
++ \\
++\end{array}$ & & $\begin{array}{l}+ \\
+ \\
+ \\
+ \\
+\end{array}$ & & & & \\
\hline $\begin{array}{l}5-5,30-31 \\
5-6,30-31 \\
5, \mathrm{CC} \\
6-1,40-41 \\
6-2,30-31 \\
\end{array}$ & . & $\begin{array}{ll} & \text { cf. } \\
& + \\
+ & \\
+ & \end{array}$ & & $\begin{array}{l}+ \\
+ \\
+ \\
+ \\
+ \\
+\end{array}$ & & $\begin{aligned}+ & + \\
& + \\
& + \\
& + \\
+ & +\end{aligned}$ & + & $\begin{array}{l}+ \\
+ \\
+ \\
+ \\
+\end{array}$ & & & & $?$ \\
\hline $\begin{array}{l}6-3,30-31 \\
6-4,30-31 \\
6-5,30-31 \\
6-6,25-26 \\
6, \mathrm{CC}\end{array}$ & & $\begin{aligned}+ & + \\
& + \\
& + \\
& +\end{aligned}$ & & $\begin{array}{l}+ \\
+ \\
+ \\
+ \\
+\end{array}$ & & $\begin{array}{l}+ \\
++ \\
++ \\
++ \\
++\end{array}$ & + & $\begin{array}{l}+ \\
+ \\
+ \\
+ \\
+\end{array}$ & & & & $?$ \\
\hline
\end{tabular}




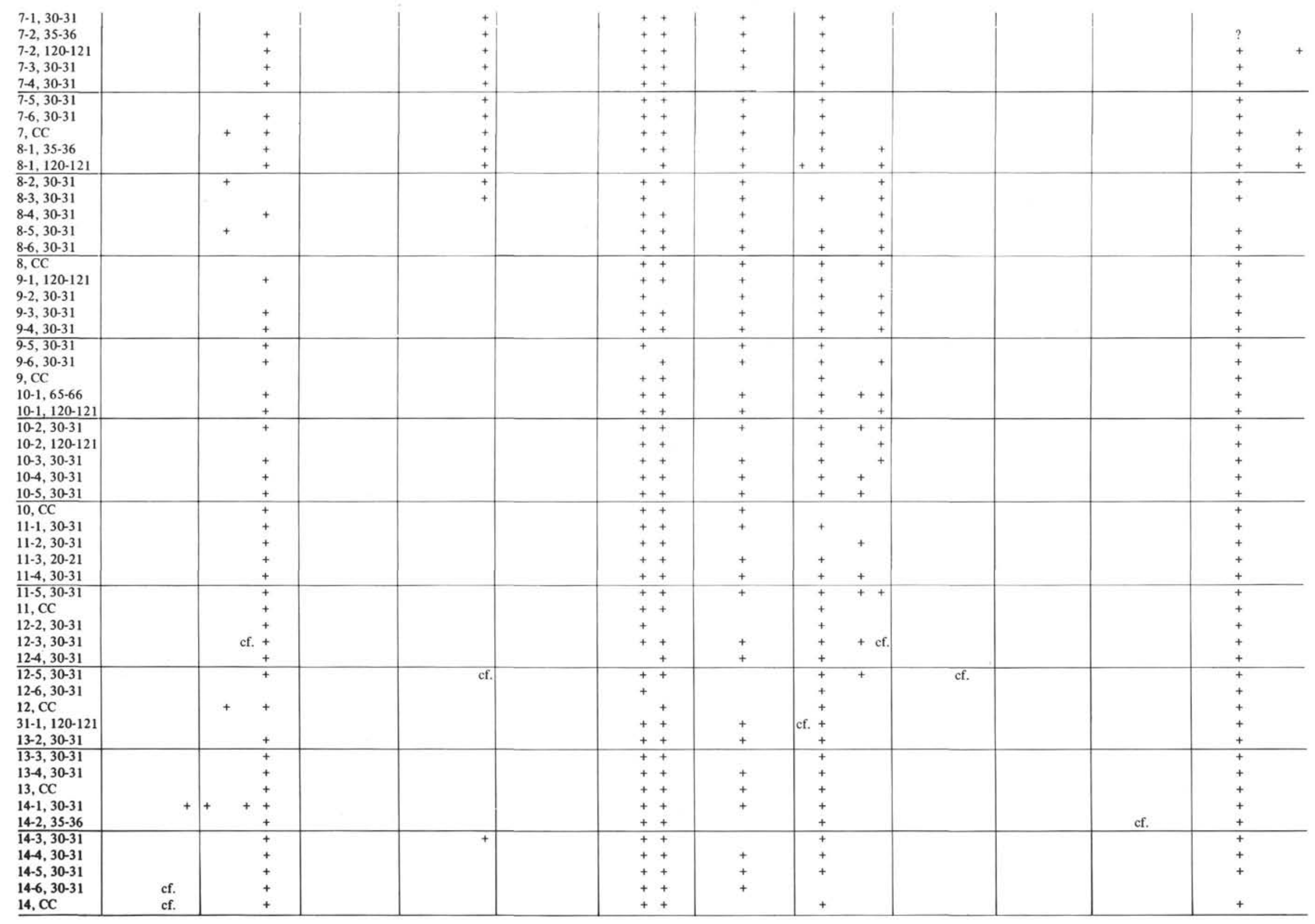




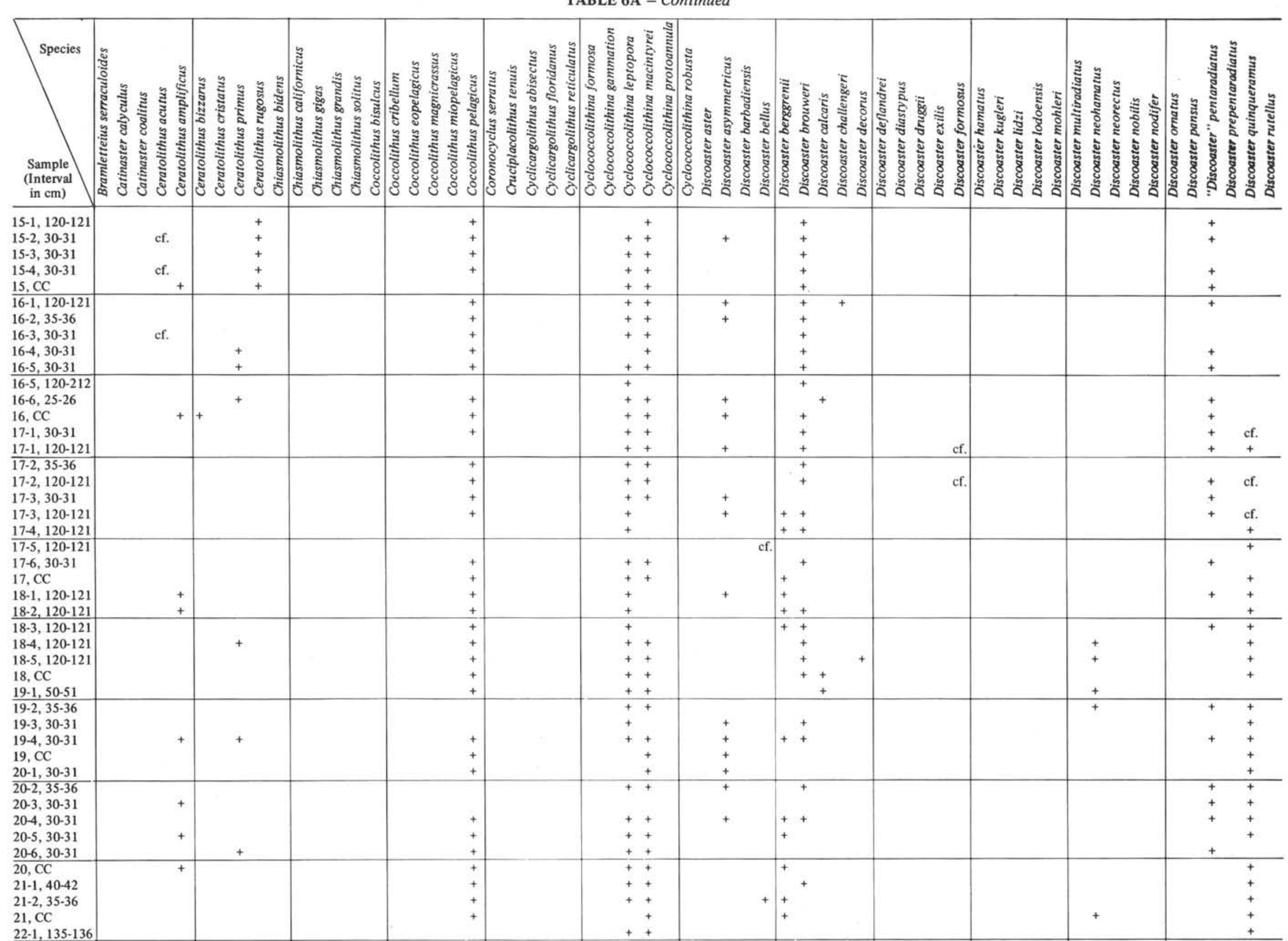




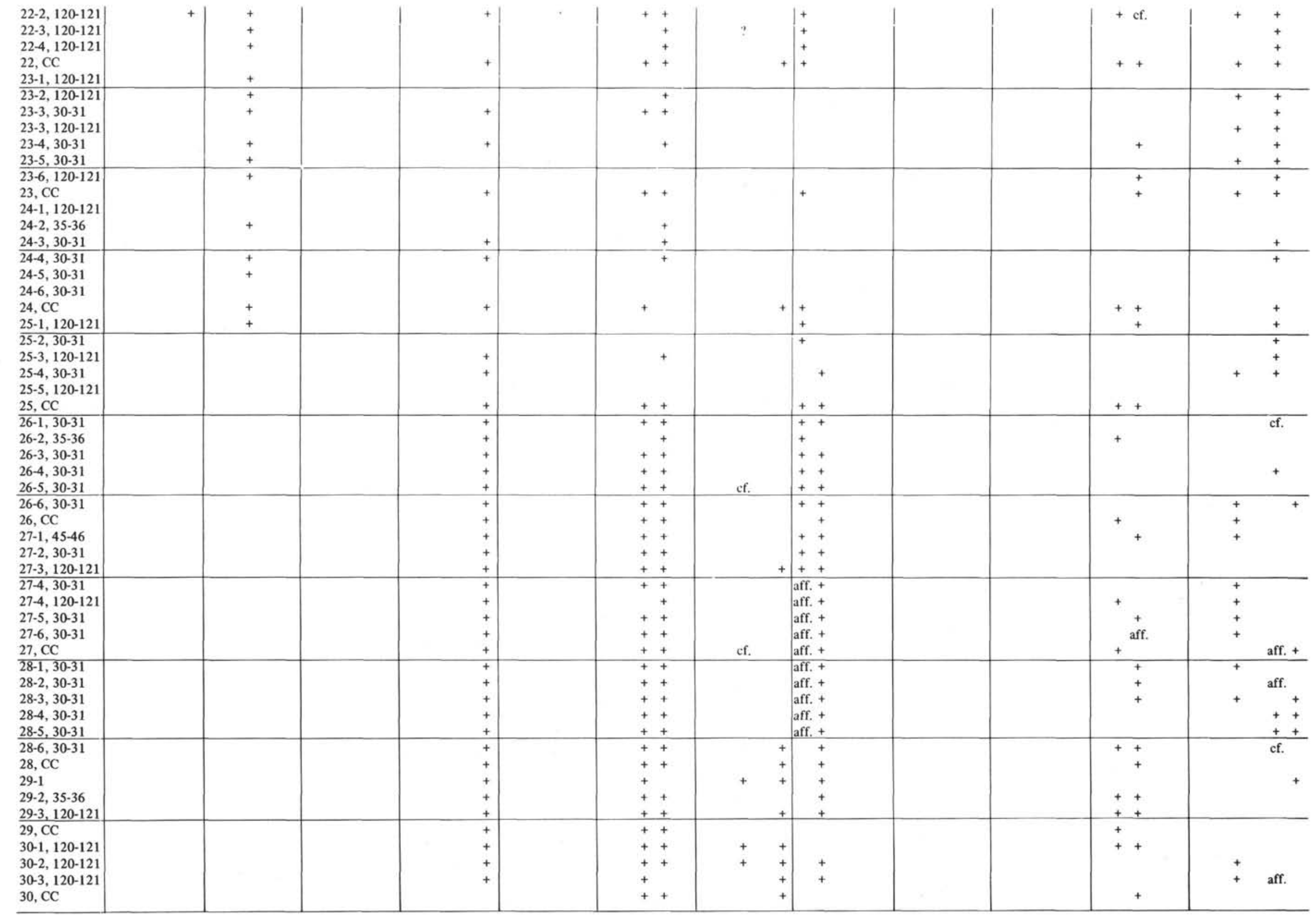




\begin{tabular}{|c|c|c|c|c|c|c|c|c|c|c|c|c|c|}
\hline $\begin{array}{l}\text { Species } \\
\text { Sample } \\
\text { (Interval } \\
\text { in } \mathrm{cm} \text { ) }\end{array}$ & 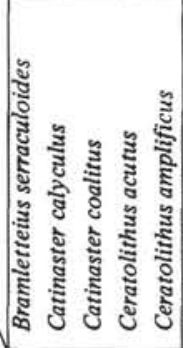 & 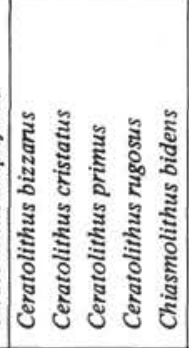 & 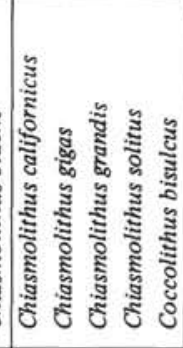 & 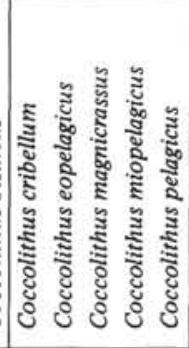 & 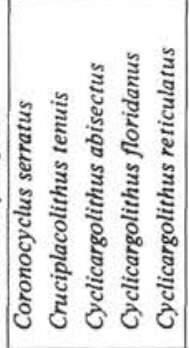 & 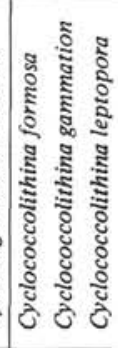 & 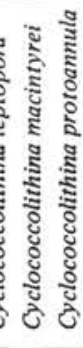 & 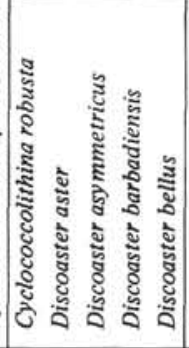 & 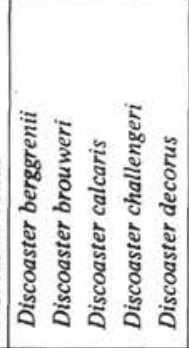 & 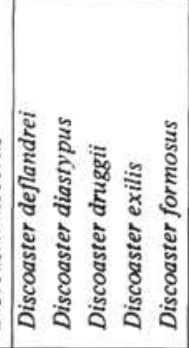 & 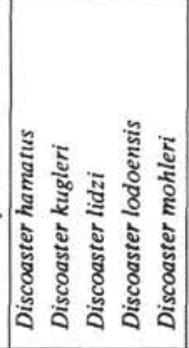 & 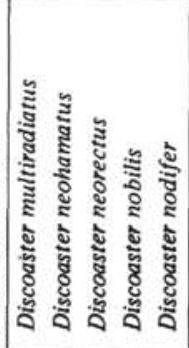 & 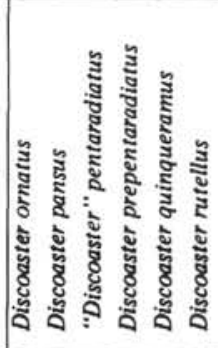 \\
\hline $\begin{array}{l}31-1,55-56 \\
31-2,30-31 \\
31-3,30-31 \\
31-4,30-31 \\
31-5,30-31\end{array}$ & & & & $\begin{array}{l}+ \\
+ \\
+ \\
+ \\
+\end{array}$ & & $\begin{array}{l}+ \\
+ \\
+ \\
+ \\
+\end{array}$ & $\begin{array}{l}+ \\
+ \\
+ \\
+ \\
+\end{array}$ & $\begin{array}{ll}+ & + \\
& + \\
& + \\
& + \\
\text { ef. } & +\end{array}$ & + & + & & $\begin{array}{l}+ \\
+\quad ? \\
+? \\
+ \\
+ \\
+\end{array}$ & + \\
\hline $\begin{array}{l}31-6,30-31 \\
31, \mathrm{CC} \\
32-1,50-51 \\
32-2,30-31 \\
32-3,30-31\end{array}$ & & & & $\begin{array}{r}+ \\
++ \\
+ \\
+ \\
+\end{array}$ & & $\begin{array}{l}+ \\
+ \\
+ \\
+ \\
+\end{array}$ & $\begin{array}{l}+ \\
+ \\
+ \\
+\end{array}$ & $\begin{array}{l}+ \\
+ \\
+\end{array}$ & & + & & $\begin{array}{l}+\quad ? \\
+\quad+ \\
++ \\
+ \\
+\end{array}$ & \\
\hline $\begin{array}{l}32-4,30-31 \\
32-5,30-31 \\
32, \mathrm{CC} \\
33-1,30-31 \\
33-2,35-36\end{array}$ & & & & + & & $\begin{array}{l}+ \\
+ \\
+ \\
+ \\
+\end{array}$ & $\begin{array}{l}+ \\
+ \\
+ \\
+\end{array}$ & + & $\begin{array}{l}+ \\
+ \\
+ \\
+\end{array}$ & & + & $\begin{array}{l}+ \\
+? \\
++ \\
+ \\
+\end{array}$ & $\begin{array}{l}\text { cf. } \\
\text { cf. } \\
+ \\
+\end{array}$ \\
\hline $\begin{array}{l}33-3,80-81 \\
33-4,120-121 \\
33-5,30-31 \\
33-5,120-121 \\
33-6,30-31\end{array}$ & & & & $\begin{array}{l}+ \\
+ \\
+ \\
+ \\
+\end{array}$ & & $\begin{array}{l}+ \\
+ \\
+ \\
+\end{array}$ & $\begin{array}{l}+ \\
+ \\
+ \\
+\end{array}$ & $\begin{array}{l}+ \\
+ \\
+ \\
+\end{array}$ & + & & $\begin{array}{l}+ \\
+\end{array}$ & $\begin{array}{l}+? \\
+ \\
+ \\
++\end{array}$ & + \\
\hline $\begin{array}{l}33, \mathrm{CC} \\
34-1,120-121 \\
34-2,120-121 \\
34-3,120-121 \\
34-4,120-121\end{array}$ & $\begin{array}{l}+ \\
+\mathrm{cf} .\end{array}$ & & & + & & $\begin{array}{l}+ \\
+ \\
+ \\
+\end{array}$ & $\begin{array}{l}+ \\
+ \\
+ \\
+\end{array}$ & + & & & $\begin{array}{l}+ \\
\text { cf. } \\
+ \\
+\end{array}$ & $\begin{array}{l}+ \\
+ \\
+ \\
+\end{array}$ & $\begin{array}{l}\text { cf. } \\
+\end{array}$ \\
\hline $\begin{array}{l}34-5,120-121 \\
34-6,120-121 \\
34, \mathrm{CC} \\
35-1,120-121 \\
35-2,30-31\end{array}$ & + & & & + & & $\begin{array}{l}+ \\
+ \\
+ \\
+ \\
+\end{array}$ & & $\begin{array}{l}+ \\
+ \\
\end{array}$ & $\begin{array}{l}+ \\
+\end{array}$ & & $\begin{array}{l}+ \\
+ \\
+ \\
+ \\
+\end{array}$ & + & + \\
\hline $\begin{array}{l}35-3,120-121 \\
35-4,120-121 \\
35, \mathrm{CC} \\
36-1,30-31 \\
36-2,30-31\end{array}$ & $\begin{array}{l}++ \\
+ \\
\text { cf. } \mathrm{cf} . \\
\text { cf. cf. }\end{array}$ & & & & & $\begin{array}{l}+ \\
+ \\
+ \\
+\end{array}$ & $\begin{array}{l}+ \\
+ \\
+ \\
+ \\
+\end{array}$ & $\begin{array}{l}+ \\
+ \\
+ \\
+ \\
+\end{array}$ & & + & $\begin{array}{l}+ \\
+ \\
+ \\
+ \\
+ \\
+\end{array}$ & + & $\begin{array}{l}+ \\
+ \\
? \\
+\end{array}$ \\
\hline \begin{tabular}{|l}
$36-3,30-31$ \\
$36-4,30-31$ \\
$36-5,30-31$ \\
$36-6,30-31$ \\
$36, \mathrm{CC}$ \\
\end{tabular} & $\begin{array}{l}\text { cf. }+ \\
\text { cf. } \\
\text { cf. cf. } \\
\text { cf. cf. } \\
+\end{array}$ & & & & & $\begin{array}{l}+ \\
+ \\
+ \\
+ \\
+\end{array}$ & $\begin{array}{l}+ \\
+ \\
+ \\
+\end{array}$ & $\begin{array}{l}+ \\
+ \\
+ \\
+ \\
+\end{array}$ & + & & $\begin{array}{l}+ \\
+ \\
+ \\
+ \\
+ \\
+ \\
+\end{array}$ & cf. & $\begin{array}{l}+ \\
+\end{array}$ \\
\hline $\begin{array}{l}37-1,30-31 \\
37-2,120-121 \\
37-3,120-121 \\
37-4,120-121 \\
37-5,120-121\end{array}$ & $\begin{array}{l}+ \\
+ \\
+ \\
+\end{array}$ & & & $\begin{array}{l}+ \\
+ \\
+ \\
+\end{array}$ & & $\begin{array}{l}+ \\
+ \\
+ \\
+\end{array}$ & $\begin{array}{l}+ \\
+ \\
+ \\
+\end{array}$ & & if. & $\begin{array}{l}+ \\
+ \\
+ \\
+\end{array}$ & cf. & & \\
\hline
\end{tabular}




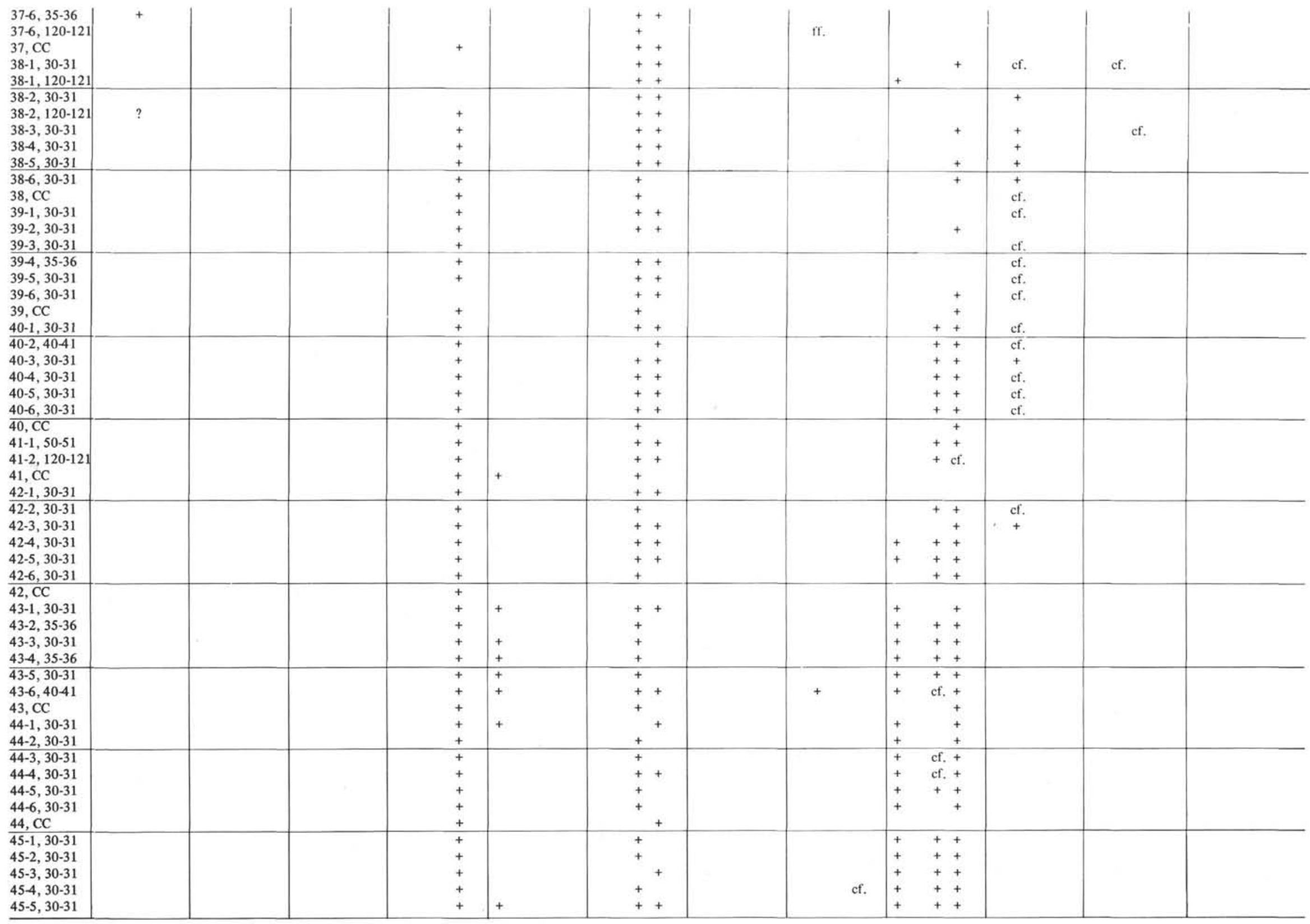




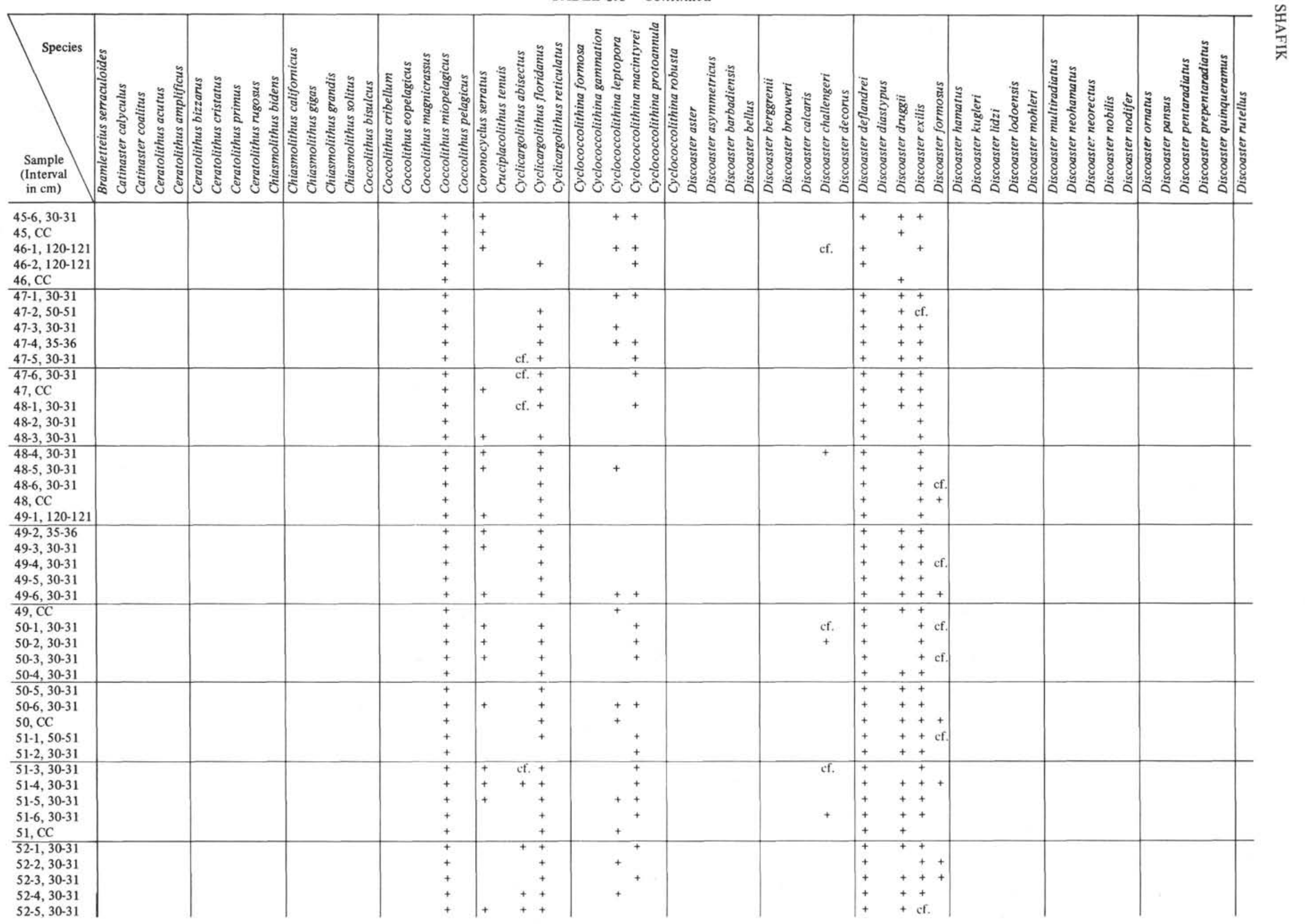




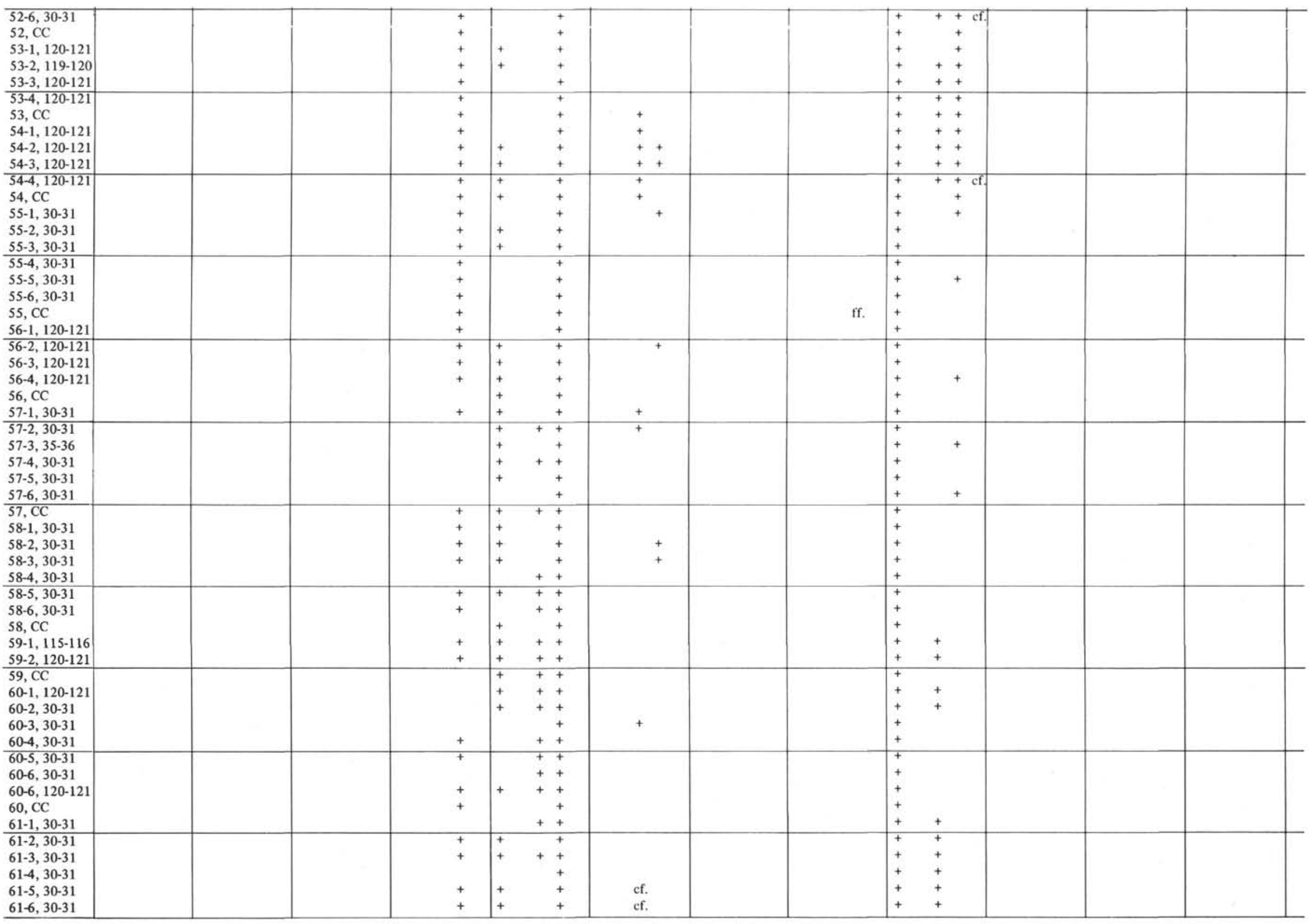




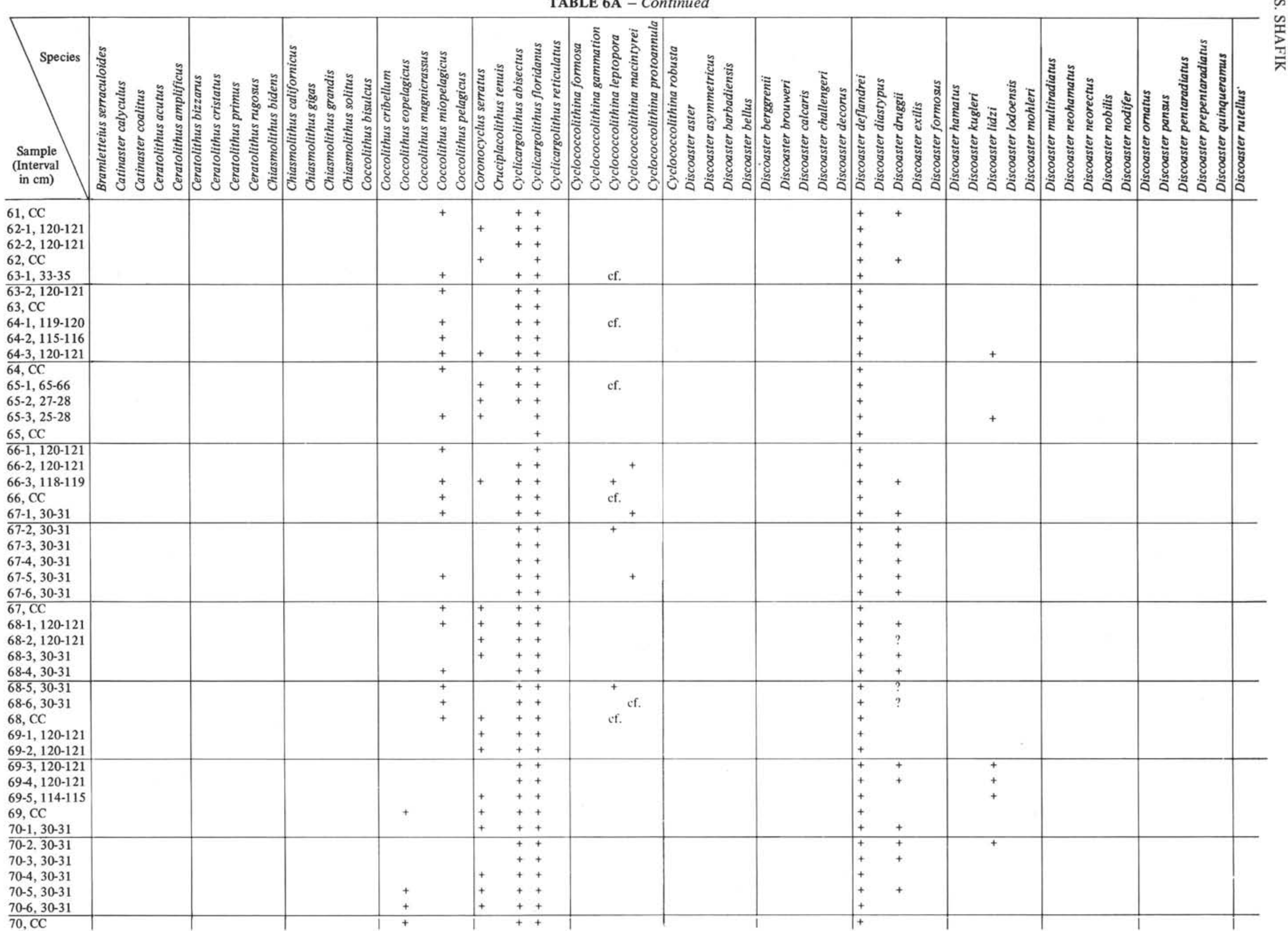




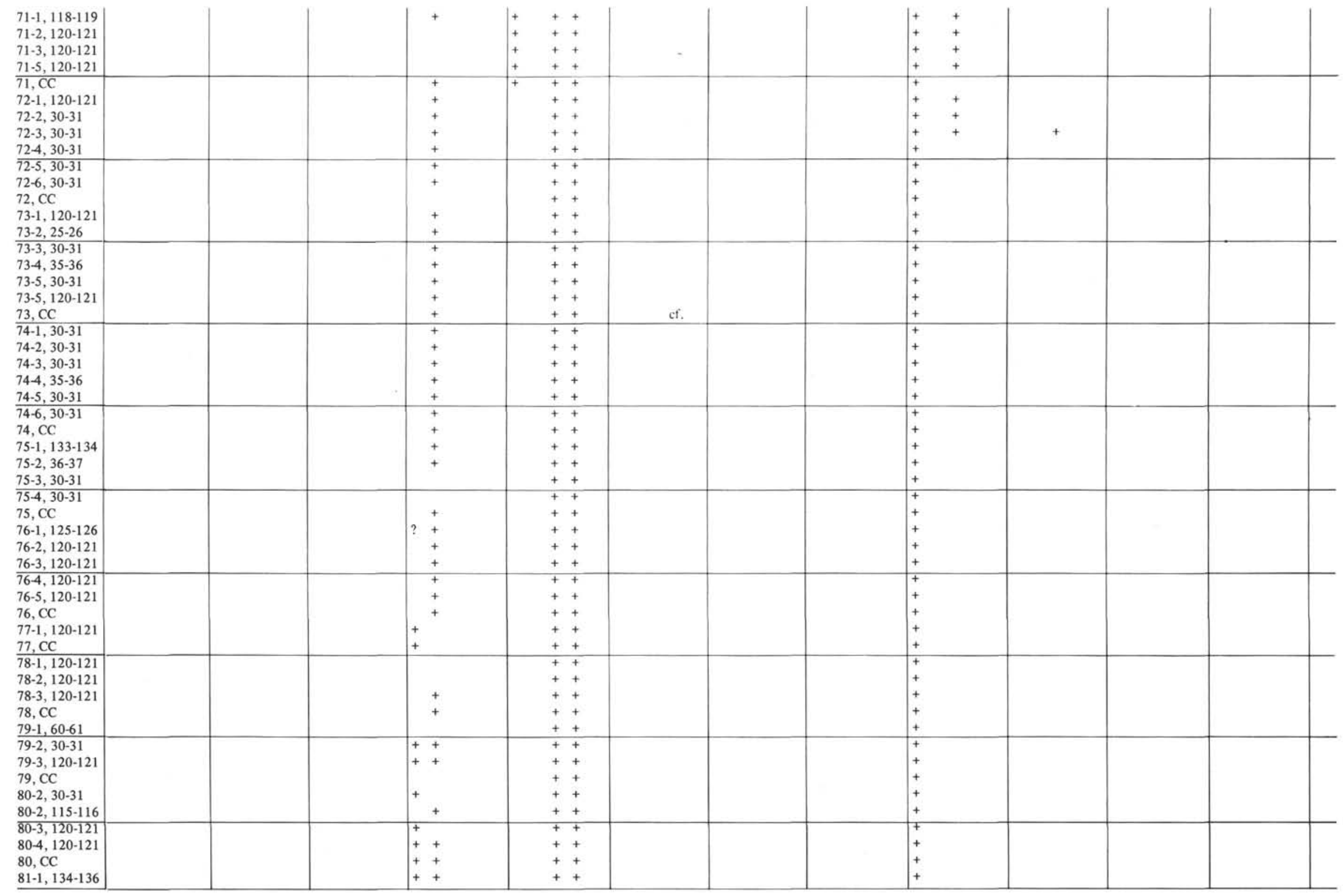


TABLE 6A - Continued

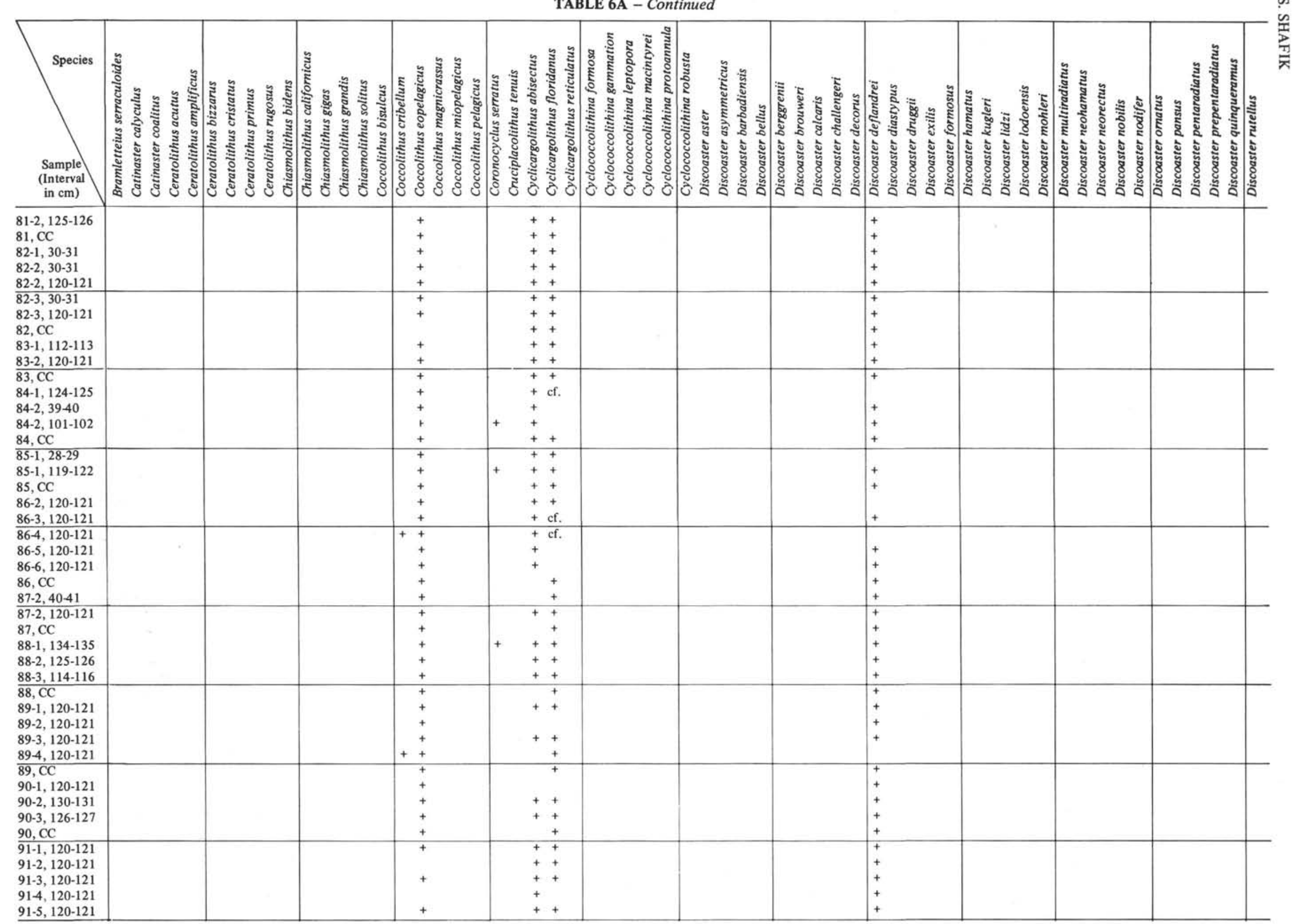




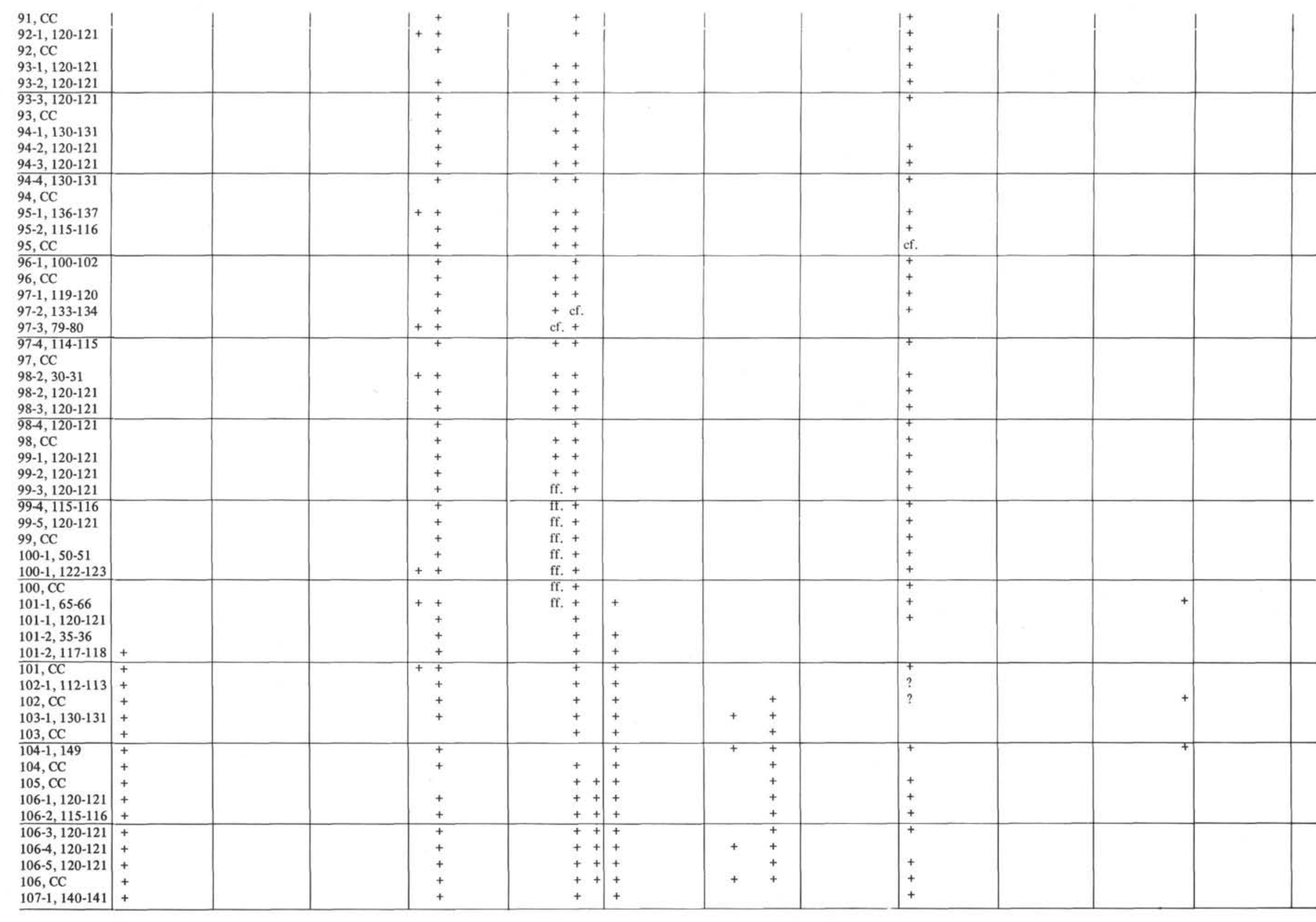


TABLE 6A - Continued

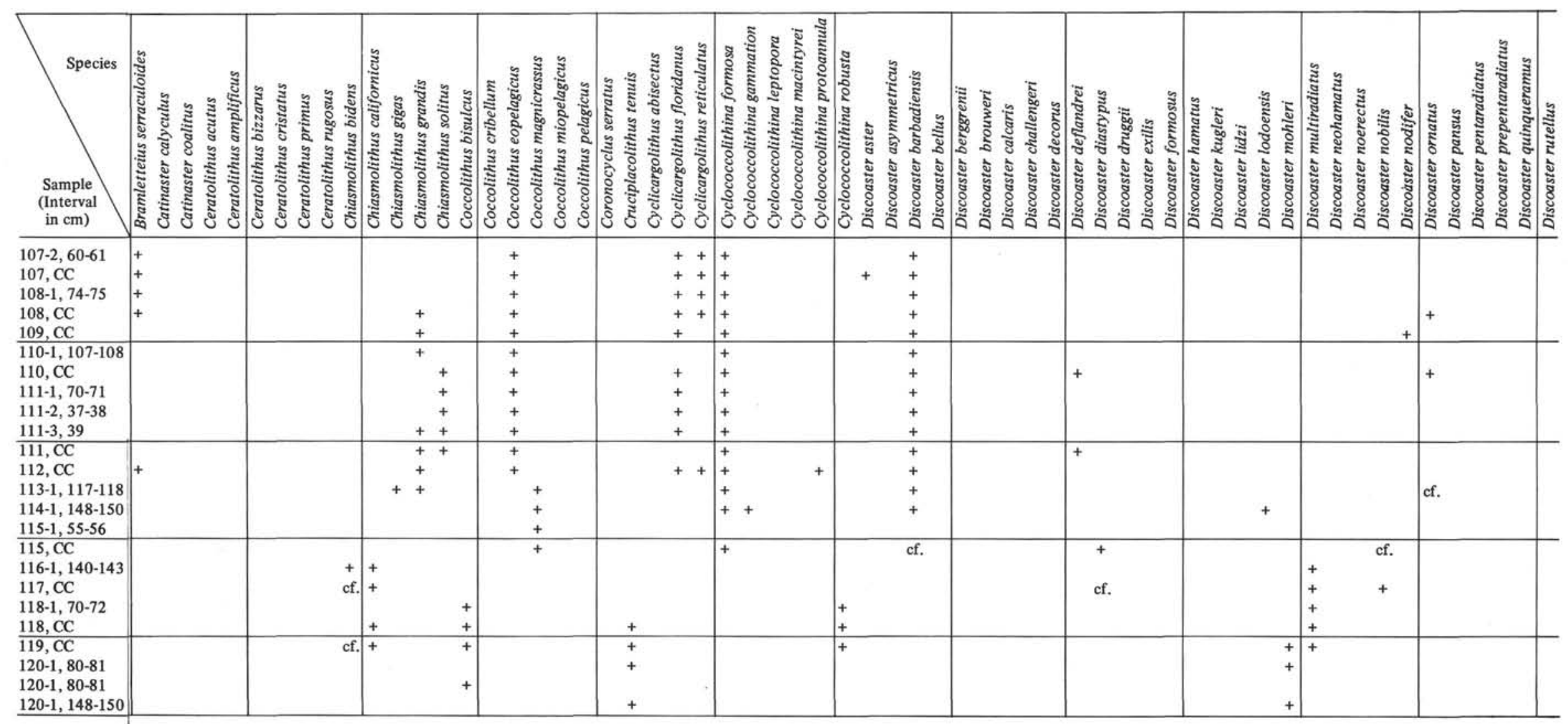




\section{Discoaster mohleri Zone (age: Middle Paleocene)}

The interval from the base range of Discoaster mohleri to the base range of Discoaster nobilis.

\section{Heliolithus kleinpellii Zone (age: Middle Paleocene)}

The interval from the base range of Heliolithus kleinpellii to the base range of Discoaster mohleri.

\section{Fasciculithus tympaniformis Zone (age: Middle Paleocene)}

The interval from the base range of Fasciculithus tympaniformis to the base range of Heliolithus kleinpellii. This Zone has not been identified among Leg 30 material.

\section{Cyclococcolithina robusta Zone (age: Early to Middle Paleocene)}

The interval from the base range of Cyclococcolithina robusta to the base range of Fasciculithus tympaniformis.

\section{Cruciplacolithus tenuis Zone (age: Early Paleocene)}

The interval from the base range of Cruciplacolithus tenuis to the base range of Cyclococcolithina robusta. $C$. tenuis develops distinct advanced forms in the upper part of this zone.

The Cretaceous/Tertiary boundary is placed between the Micula mura and the C. tenuis zones.

\section{Micula mura Zone (age: Late Maestrichtian)}

The interval from the base range of Micula mura to the base range of Cruciplacolithus tenuis.

\section{Lithraphidites quadratus Zone (age: Middle Maestrichtian)}

The interval from the top range of Tetralithus trifidus to the base range of Micula mura.

\section{Tetralithus trifidus Zone (age: Campanian- Maestrichtian)}

The total range of Tetralithus trifidus.

\section{Broinsonia parca Zone (age: Campanian)}

The interval from the top range of Eiffellithus augustus to the base range of Tetralithus trifidus. Apparently, this zone is a comparatively short interval.

\section{Eiffellithus augustus Zone (age: Campanian)}

The interval from the base range of Broinsonia parca to the top range of Eiffellithus augustus.

\section{Gartnerago obliquun Zone (age: Santonian)}

The interval from the top range of Marthasterites furcatus to the base range of Broinsonia parca. This zone has not been identified in Leg 30 material.

\section{Marthasterites furcatus Zone (age: Santonian to Coniacian)}

The total range of Marthasterites frucatus.

\section{Micula decussata Zone (age: Late Turonian)}

The interval from the base range of Micula decussata to the base range of Marthasterites furcatus.
Zonation of the remaining part of the Upper Cretaceous has not been attempted and only the Eiffellithus turriseiffeli Zone from the Lower Cretaceous has been identified among Leg 30 material.

Eiffellithus turriseiffeli Zone (age: Late Albian)

The lower boundary is recognized by the base range of the nominate species and the upper boundary by the base range of Chiastozygus cuneatus (see Roth, 1973).

\section{UNCONFORMITIES IN THE SOUTHWEST PACIFIC}

\section{Discussion}

The biostratigraphic recognition of unconformities is related primarily to the resolution of the fossils used and depends largely on the sampling intervals. Accordingly, disturbance in the biostratigraphic sequence (reworking and/or contamination); inherent deficiency in the zonal scheme (e.g., provincialism of some zonal forms); poor preservation and induced diversity limitations (selective dissolution and diagenesis); and long gaps in sampling (especially if these involve thin biostratigraphic units) may result in uncertain perception of unconformities. Deep-sea coring is not always continuous and recovery is variable; the location of biostratigraphic boundaries between spaced cores or within a poorly recovered core might indicate a reduced accumulation rate rather than an actual break.

The hiatuses or suspected hiatuses detected during routine biostratigraphic investigation are documented below. Coeval hiatuses at two sites from Leg 21 are mentioned also. The data for the Cenozoic are summarized graphically in Tables 7 and 8.

\section{Pliocene-Quaternary}

Paleontologic and lithologic evidence indicate the occurrence of two hiatuses within the calcareous oozes of Core 288-2; the hiatuses are apparently of small magnitude. The younger hiatus (intra-Pleistocene) is within Section 2 and probably represented by a sediment color change at $50 \mathrm{~cm}$; derived elements occur at and below this level; Gephyrocapsa oceanica has its initial appearance in Sample 288-2-2, 24-26 cm. An abrupt foraminferal change exists at the same level and a disconformity is inferred. The older hiatus (PliocenePleistocene) is within Section 5 and is partly obscured by the presence of reworked forms above and below it. However, Gephyrocapsa caribbeanica occurs rarely in Sample 288-2-5, 30-31 cm above a glass ash band (located between 35 and $45 \mathrm{~cm}$ ) which probably represents the hiatus.

A doubtful hiatus may be placed between the upper Pliocene Sample 288-5, CC and the upper Miocene Section 288-6-1; coring gap $(9.5 \mathrm{~m})$ between these cores is the main cause of doubt. However, rates of sedimentation at Site 289 during the Pliocene were sufficiently high to support the suggestion of a hiatus.

In Hole 285, the top two sections of Core 2 are dated as early Pliocene (a maximum age) and Section 3 is placed tentatively in the upper Miocene Discoaster quinqueramus Zone; reworking hinders precise zonal 


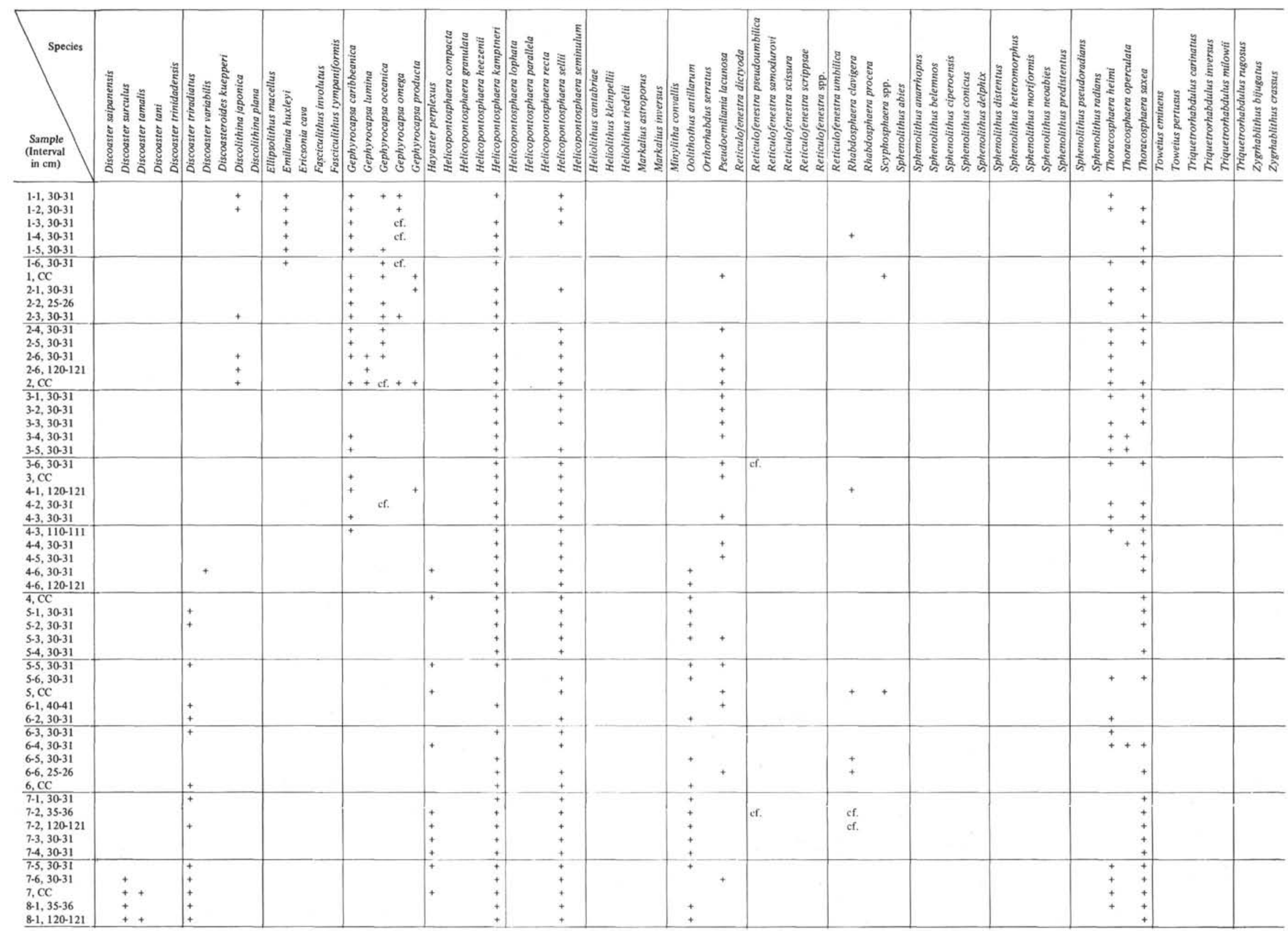




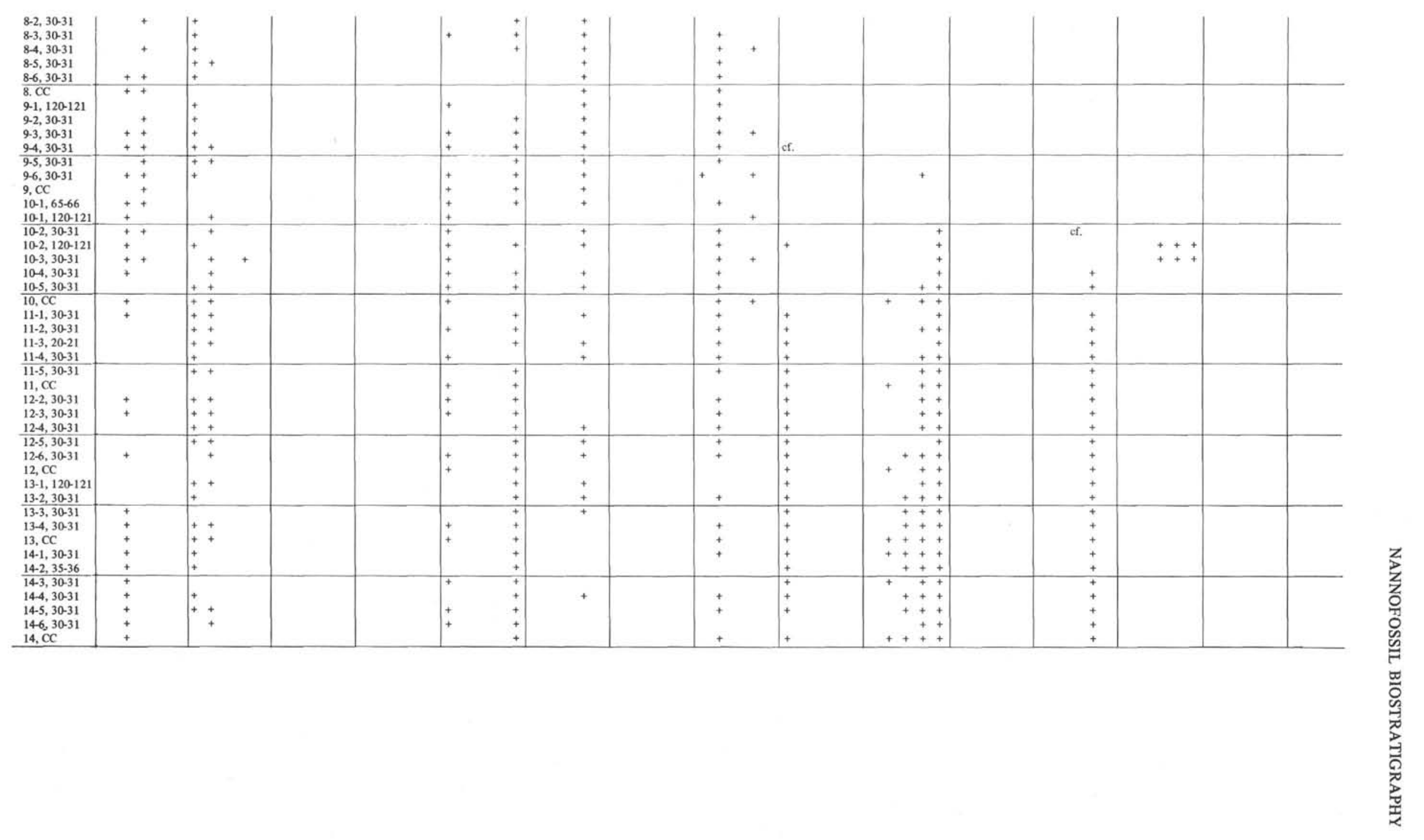




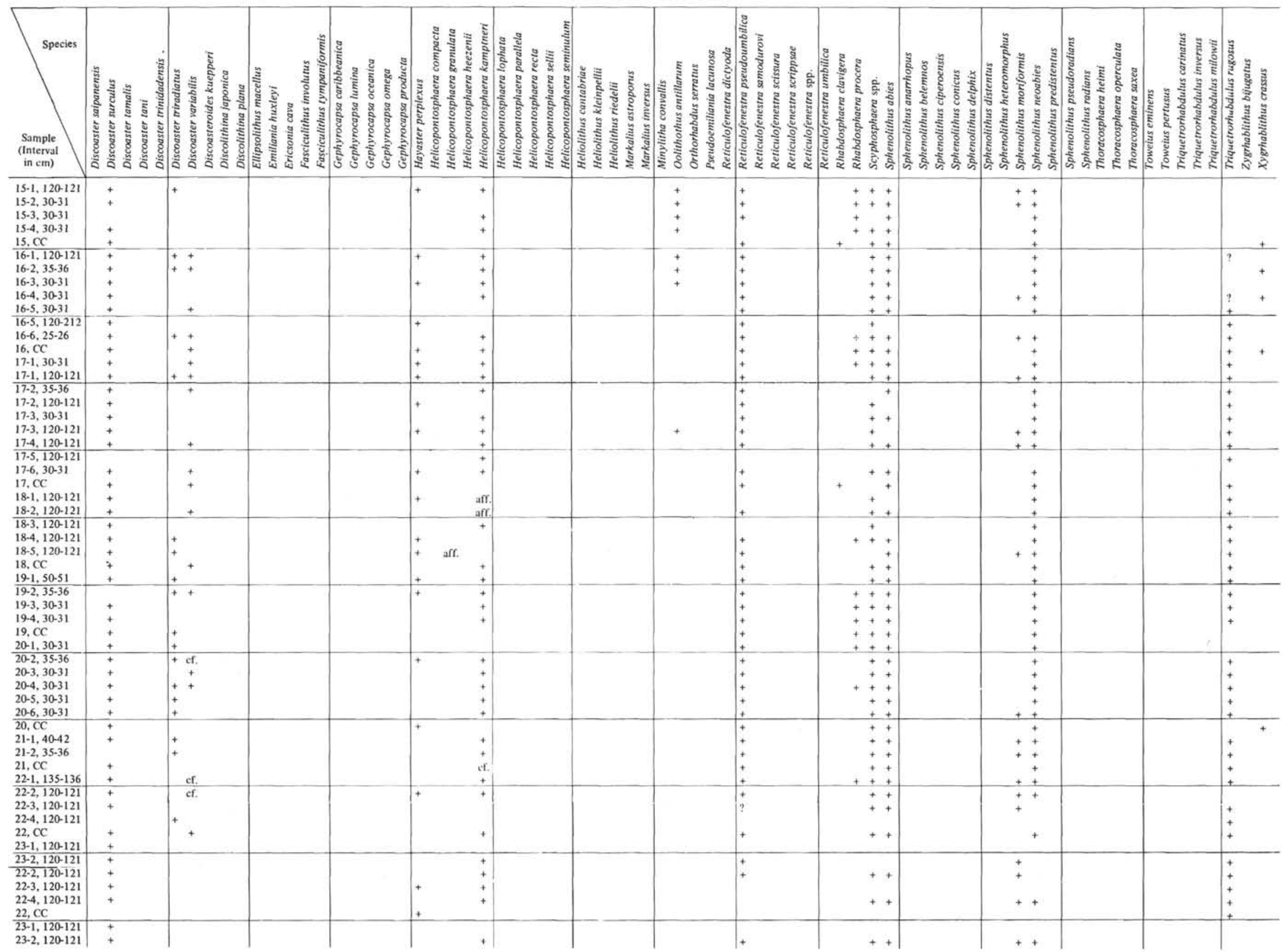




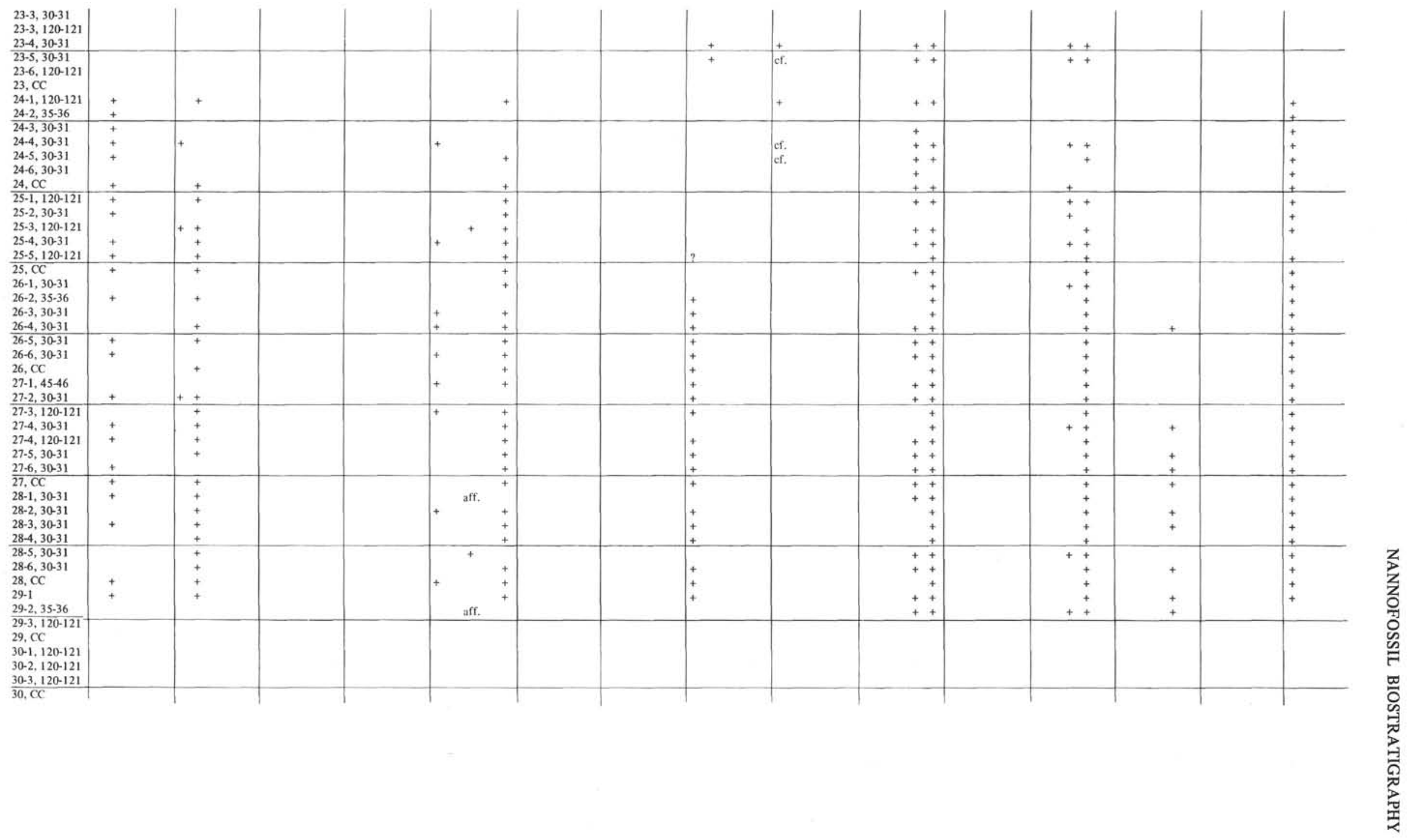




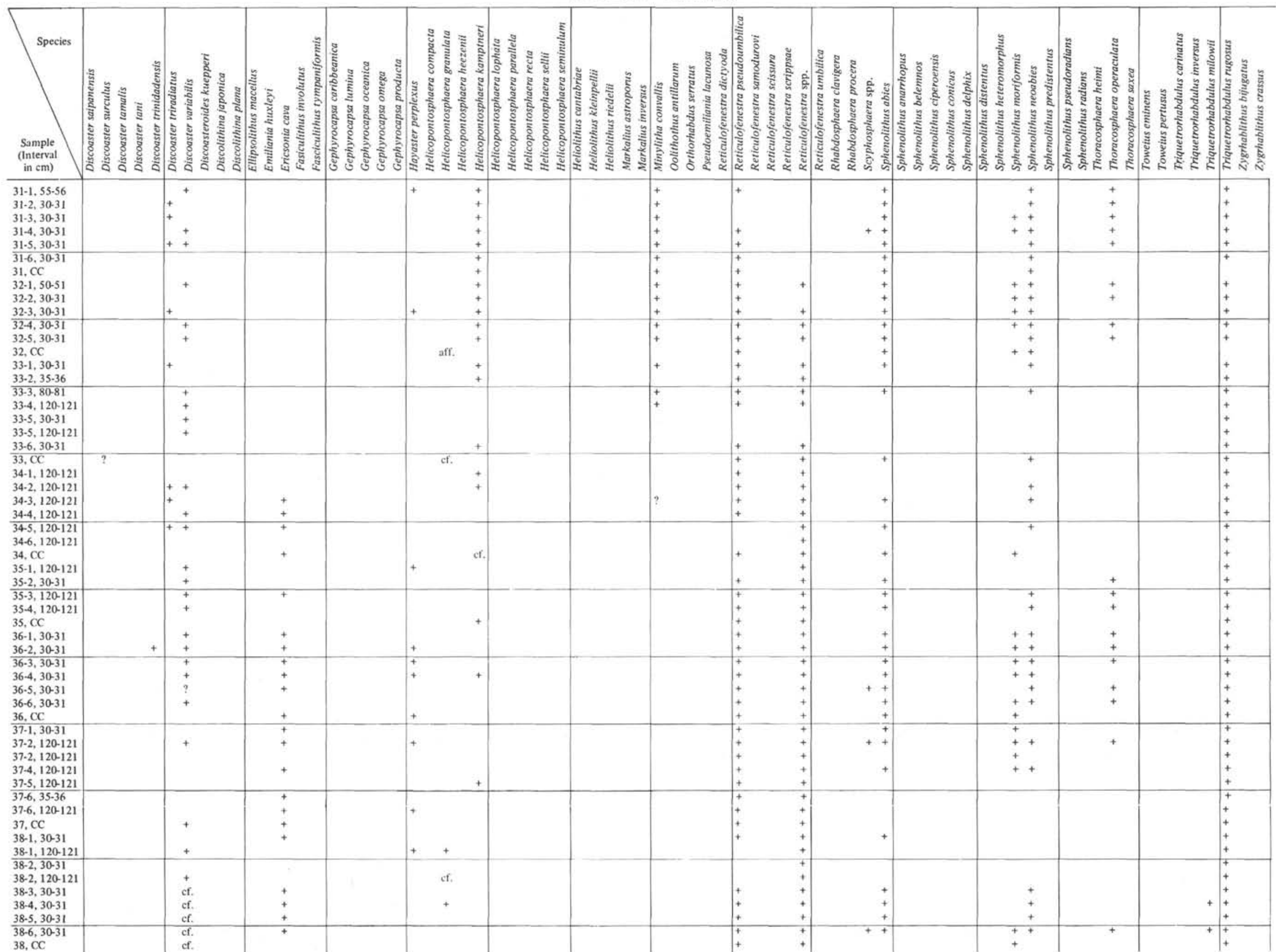




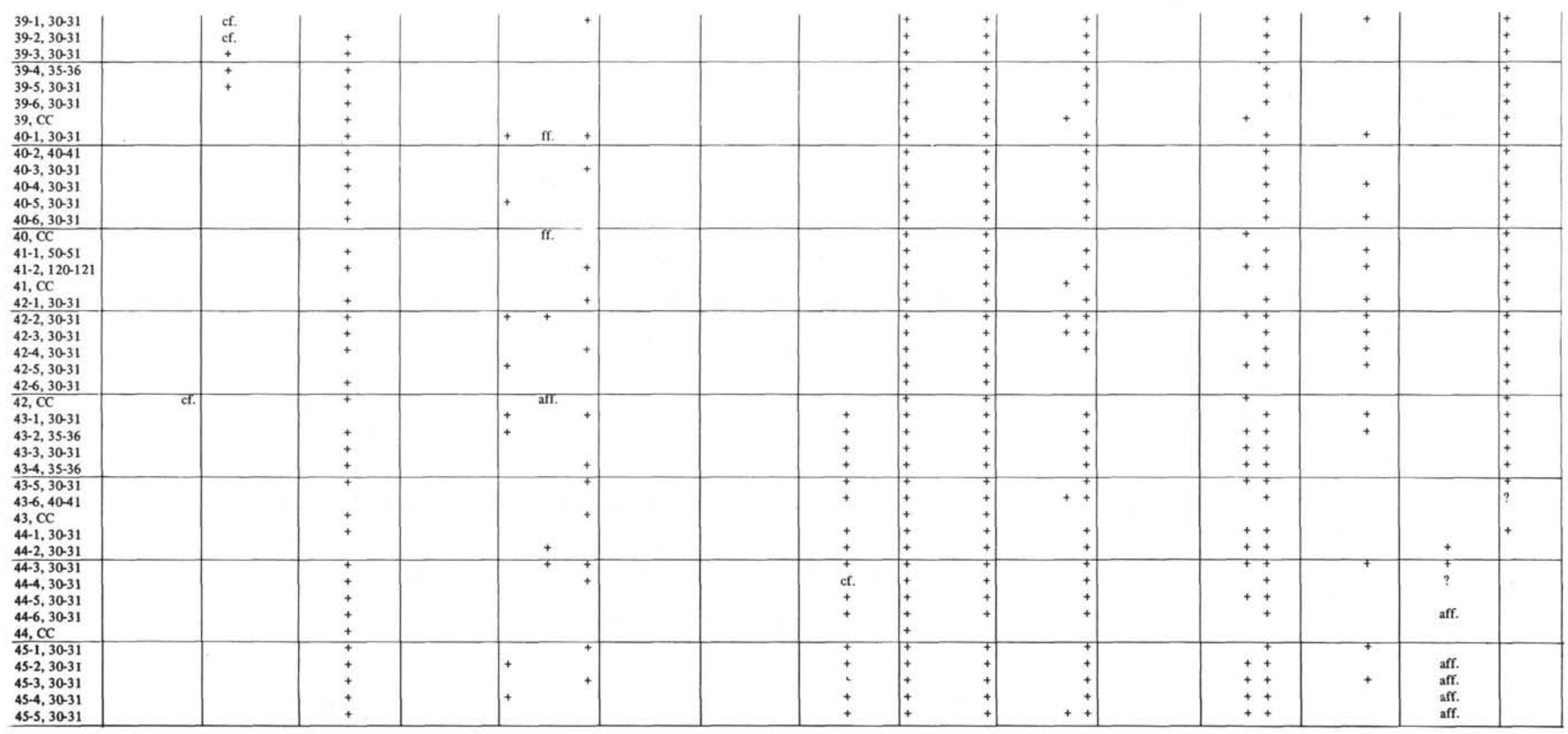

侗 


\begin{tabular}{|c|c|c|c|c|c|c|c|c|c|c|c|c|c|c|c|}
\hline Species & 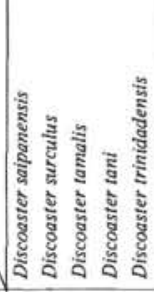 & 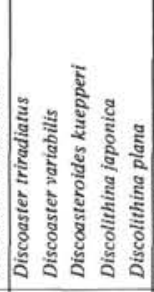 & 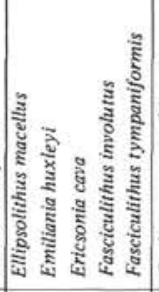 & 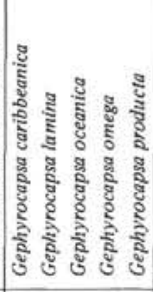 & 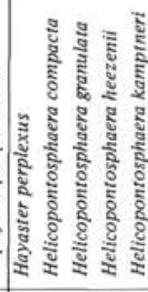 & 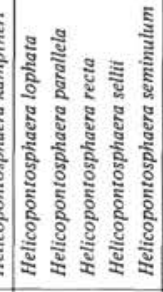 & 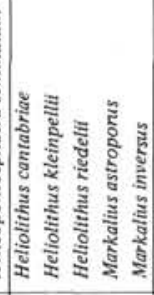 & 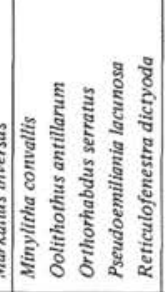 & 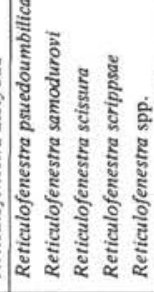 & 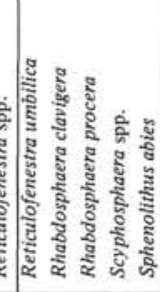 & 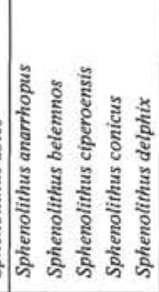 & 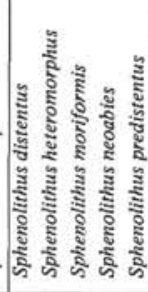 & 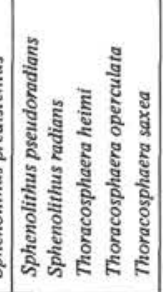 & 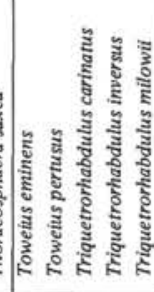 & 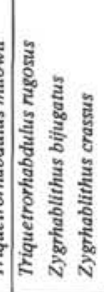 \\
\hline $\begin{array}{l}45-6,30-31 \\
45, C C \\
46-1,120-121 \\
46-2,120-121 \\
46, C C\end{array}$ & & & $\begin{array}{l}+ \\
+ \\
+\end{array}$ & & $\begin{array}{ll}+ & + \\
+ & + \\
+ & +\end{array}$ & & & & $\begin{array}{lll}+ & + \\
+ & & \\
+ & & \\
+ & & +\end{array}$ & $\begin{array}{l}+ \\
+ \\
+\end{array}$ & & $\begin{array}{r}+ \\
++ \\
++\end{array}$ & $\begin{array}{l}+ \\
+\end{array}$ & & \\
\hline $\begin{array}{l}47-1,30-31 \\
47-2,50-51 \\
47-3,30-31 \\
47-4,35-36 \\
47-5,30-31\end{array}$ & & $\begin{array}{c}+ \\
\text { ef. }\end{array}$ & $\begin{array}{l}+ \\
+ \\
+\end{array}$ & & $\begin{array}{r}+ \\
+ \\
+ \\
+ \\
+\end{array}$ & & & cf. & $\begin{array}{lll}+ & + \\
+ & & \\
+ & & + \\
+ & & \\
+ & & \end{array}$ & $\begin{array}{r}+ \\
++ \\
+ \\
+ \\
++ \\
\end{array}$ & + & $\begin{array}{r}++ \\
+ \\
++ \\
++ \\
++ \\
\end{array}$ & $\begin{array}{l}+ \\
+ \\
+\end{array}$ & & \\
\hline $\begin{array}{l}47-6,30-31 \\
47, C C \\
48-1,30-31 \\
48-2,30-31 \\
48-3,30-31 \\
\end{array}$ & & + & & & $\begin{array}{l}+ \\
+ \\
+\end{array}$ & & & & $\begin{array}{l}\text { cr. } \\
\text { cf. } \\
+ \\
+ \\
+ \\
+\end{array}$ & + & & $\begin{array}{l}++ \\
++ \\
+ \\
++ \\
++\end{array}$ & $\begin{array}{l}+ \\
+ \\
+\end{array}$ & aff. & \\
\hline $\begin{array}{l}48-4,30-31 \\
48-5,30-31 \\
48-6,30-31 \\
48, \mathrm{CC} \\
49-1,120-121\end{array}$ & + & & + & & $\begin{array}{l}+ \\
+ \\
+\end{array}$ & & & & $\begin{array}{l}+ \\
+ \\
+ \\
+ \\
+ \\
+\end{array}$ & $\begin{array}{r}++ \\
++ \\
+ \\
+\end{array}$ & & $\begin{array}{l}+++ \\
++ \\
++ \\
++ \\
++\end{array}$ & $\begin{array}{l}+ \\
+ \\
+ \\
+\end{array}$ & & \\
\hline $\begin{array}{l}49-2,35-36 \\
49-3,30-31 \\
49-4,30-31 \\
49-5,30-31 \\
49-6,30-31 \\
\end{array}$ & & & $\begin{array}{l}+ \\
+\end{array}$ & & $\begin{array}{l}+ \\
+\end{array}$ & & & $\begin{array}{l}\text { ef. } \\
\text { of. }\end{array}$ & $\begin{array}{l}+ \\
+ \\
+ \\
+ \\
+ \\
+ \\
+\end{array}$ & $\begin{array}{l}++ \\
+\end{array}$ & + & $\begin{array}{l}++ \\
++ \\
++ \\
++ \\
+\end{array}$ & $\begin{array}{l}+ \\
+ \\
+ \\
+ \\
+\end{array}$ & & \\
\hline $\begin{array}{l}49, \mathrm{CC} \\
50-1,30-31 \\
50-2,30-31 \\
50-3,30-31 \\
50-4,30-31\end{array}$ & & $\begin{array}{l}+ \\
+ \\
\end{array}$ & $\begin{array}{l}+ \\
+ \\
+ \\
+\end{array}$ & & $\begin{array}{lll}+ & & + \\
+ & \text { ef. } & + \\
+ & + \\
& & +\end{array}$ & & & ef. & $\begin{array}{l}+ \\
\vdots \\
\vdots \\
+\end{array}$ & $\begin{array}{l}++ \\
+ \\
+ \\
++\end{array}$ & & $\begin{array}{l}+ \\
+ \\
++ \\
++ \\
++\end{array}$ & + & & \\
\hline $\begin{array}{l}50-5,30-31 \\
50-6,30-31 \\
50, \mathrm{CC} \\
51-1,50-51 \\
51-2,30-31\end{array}$ & + & ct. & $\begin{array}{l}+ \\
+ \\
+ \\
+\end{array}$ & & $\begin{array}{r}+ \\
+ \\
+ \\
+ \\
+\end{array}$ & & & & $\begin{array}{l}+ \\
\text { cf. } \\
\text { cf. }\end{array}$ & $\begin{array}{r}+ \\
+ \\
+ \\
++\end{array}$ & & $\begin{array}{l}+ \\
+ \\
++ \\
++ \\
++ \\
++\end{array}$ & + & & \\
\hline $\begin{array}{l}51-3,30-31 \\
51-4,30-31 \\
51-5,30-31 \\
51-6,30-31 \\
51, \mathrm{CC} \\
\end{array}$ & & $\begin{array}{l}+ \\
+\end{array}$ & $\begin{array}{l}+ \\
+ \\
+ \\
+\end{array}$ & & $\begin{array}{l}+ \\
+ \\
+ \\
+\end{array}$ & & & & & $\begin{array}{l}++ \\
+ \\
+ \\
++\end{array}$ & & $\begin{array}{l}++ \\
++ \\
++ \\
++ \\
++ \\
+\end{array}$ & + & & \\
\hline $\begin{array}{l}52-1,30-31 \\
52-2,30-31 \\
52-3,30-31 \\
52-4,30-31 \\
52-5,30-31 \\
\end{array}$ & & & + & & + & & & & & + & & $\begin{array}{l}++ \\
+ \pm \\
+ \pm \\
+ \pm \\
++ \\
+\end{array}$ & $\begin{array}{l}+ \\
+ \\
+\end{array}$ & & \\
\hline $\begin{array}{l}52-6,30-31 \\
52, \mathrm{CC} \\
53-1,120-121 \\
53-2,110-120 \\
53-3,120-121\end{array}$ & + & & $\begin{array}{l}+ \\
+ \\
+ \\
+ \\
+\end{array}$ & & $\begin{array}{l}+ \\
+ \\
+ \\
+ \\
+ \\
+\end{array}$ & & & & cf. & & & $\begin{array}{l}++ \\
++ \\
++ \\
++ \\
++\end{array}$ & $\begin{array}{l}+ \\
+ \\
+\end{array}$ & & \\
\hline $\begin{array}{l}53-4,120-121 \\
53, C C \\
54-1,120-121 \\
54-2,120-121 \\
54-3,120-121 \\
\end{array}$ & + & & $\begin{array}{l}+ \\
+ \\
+ \\
+ \\
+\end{array}$ & & $\begin{array}{lll} & & + \\
+ & + & + \\
+ & & + \\
+ & & \\
+\end{array}$ & & & & $\begin{array}{l}\text { ef. } \\
+ \\
+ \\
+ \\
+ \\
\text { ef. }\end{array}$ & + & & $\begin{array}{l}+ \\
+ \\
+ \\
++ \\
+ \\
+\end{array}$ & + & & \\
\hline $\begin{array}{l}54-4,120-121 \\
54, C C\end{array}$ & + & cf. & + & & & & & & + & & & + & + & & \\
\hline
\end{tabular}




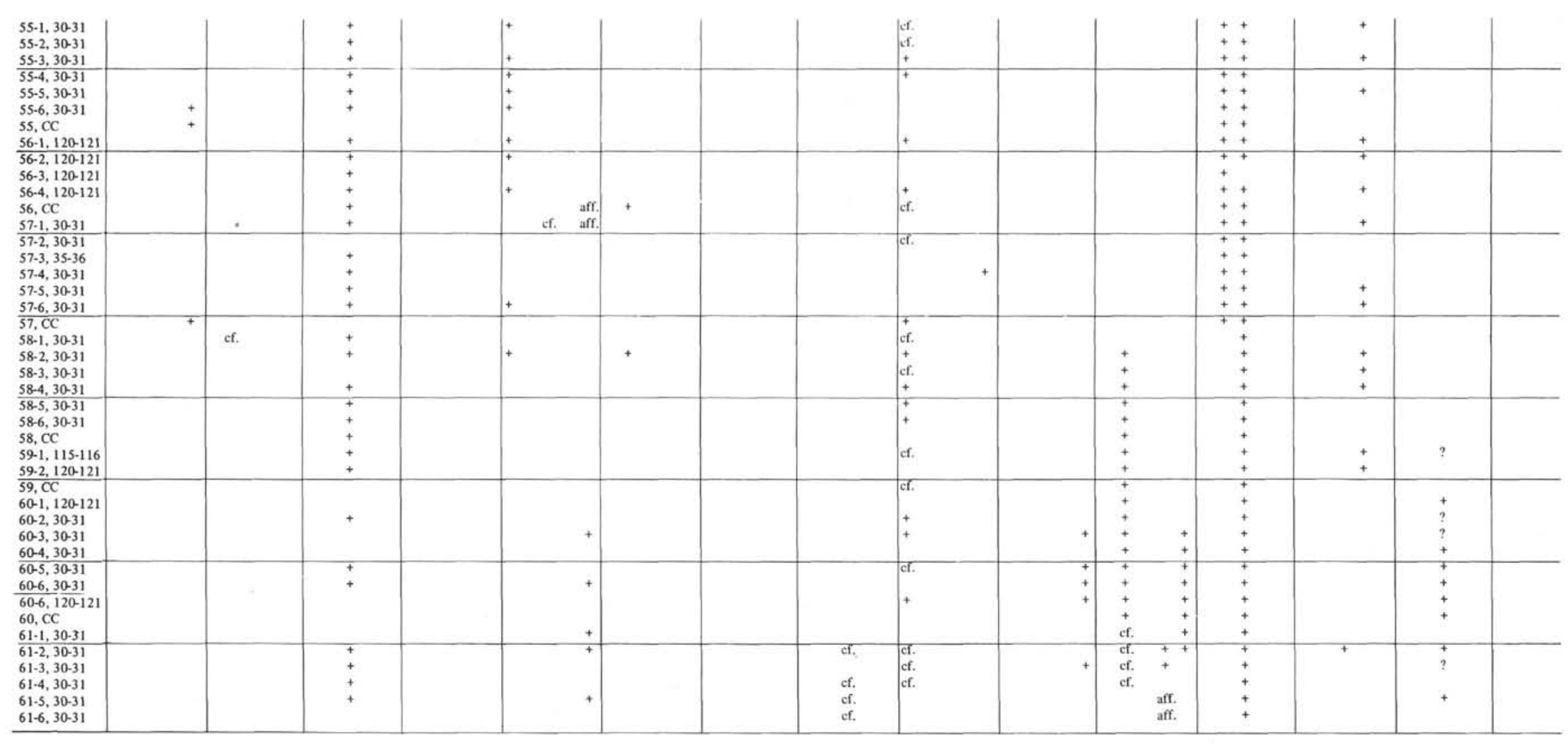




\section{Species}

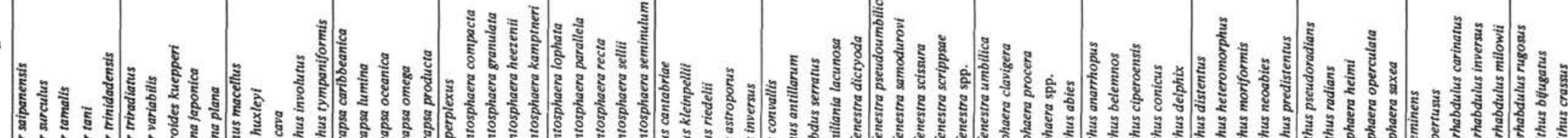
Sole.

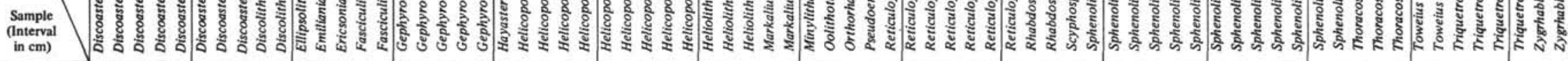

$61, \mathrm{CC}$

$62-1,120-121$

$62-2,120-12$
$62, \mathrm{CC}$

$\frac{63-1,33-35}{63-2,120-121}$

63, CC

64-1. 119-120

$64-2,115-116$
$64-3,120-121$

$64, \mathrm{CC}$

65-1, $65-66$
$65-2,27-28$

65-3, 25-28

$\frac{65, \mathrm{CC}}{66-1.120-121}$

66-2, 120-121

$66-3,118-11$

sic

$\frac{67-1,30-31}{67-2,30-31}$

$67-3,30-31$

$67-4,30-31$

$67-6,30-31$

67, CC

68-1, 120-121

68-3, 30-31

$\frac{68-4,30-31}{68-5,30-31}$

$68-6,30-31$

69-1, 120-12

69-2, 120-121

$69-3,120-121$

69-4, 120-121

$69, \mathrm{CC}$

70-1, 30-3

$70-2,30-31$

$70-3,30-31$
$70-4,30-31$

70-5, 30-31

$70-6,30-31$

71-1, 118-119

$71-2,120-121$
$71-3,120-121$

71-5, 120-121

$71, \mathrm{CC}$

$72-1,120-121$
$72-2,30-31$

$72-2,30-31$
$72-4,30-31$

$72-5,30-31$
$72-6,30-31$

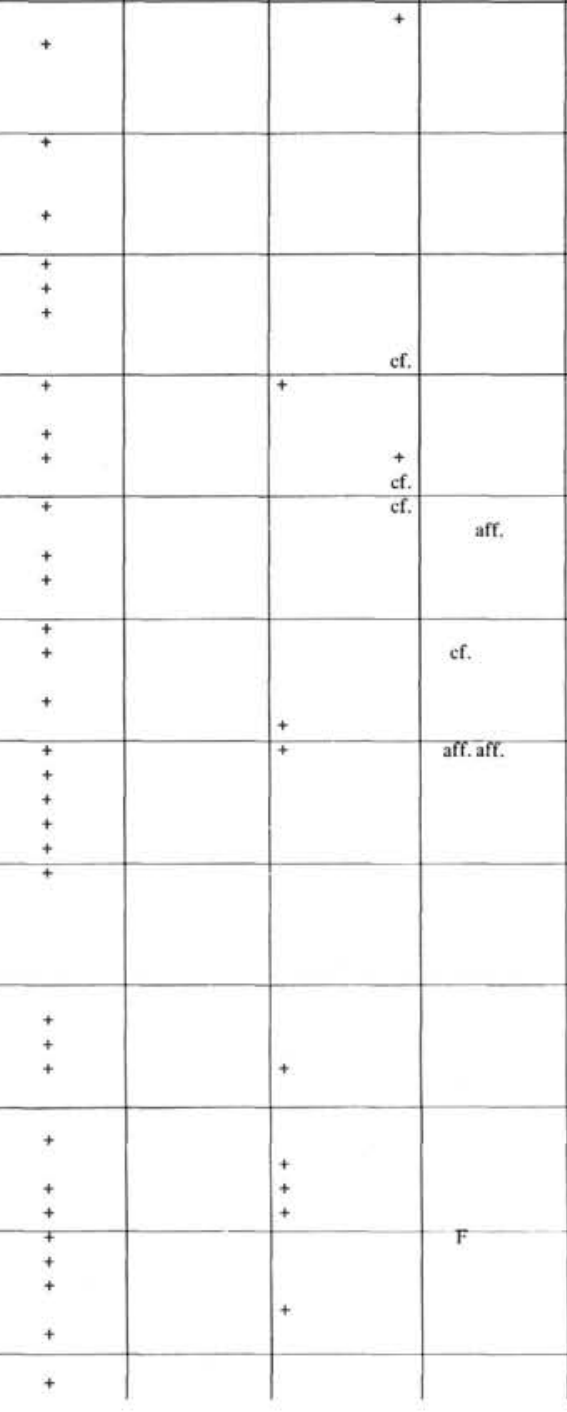

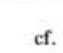

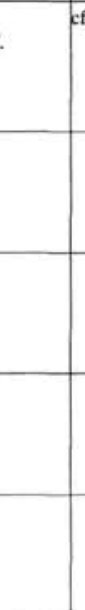

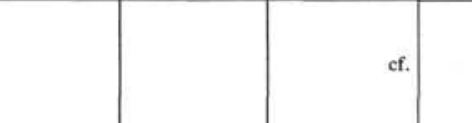




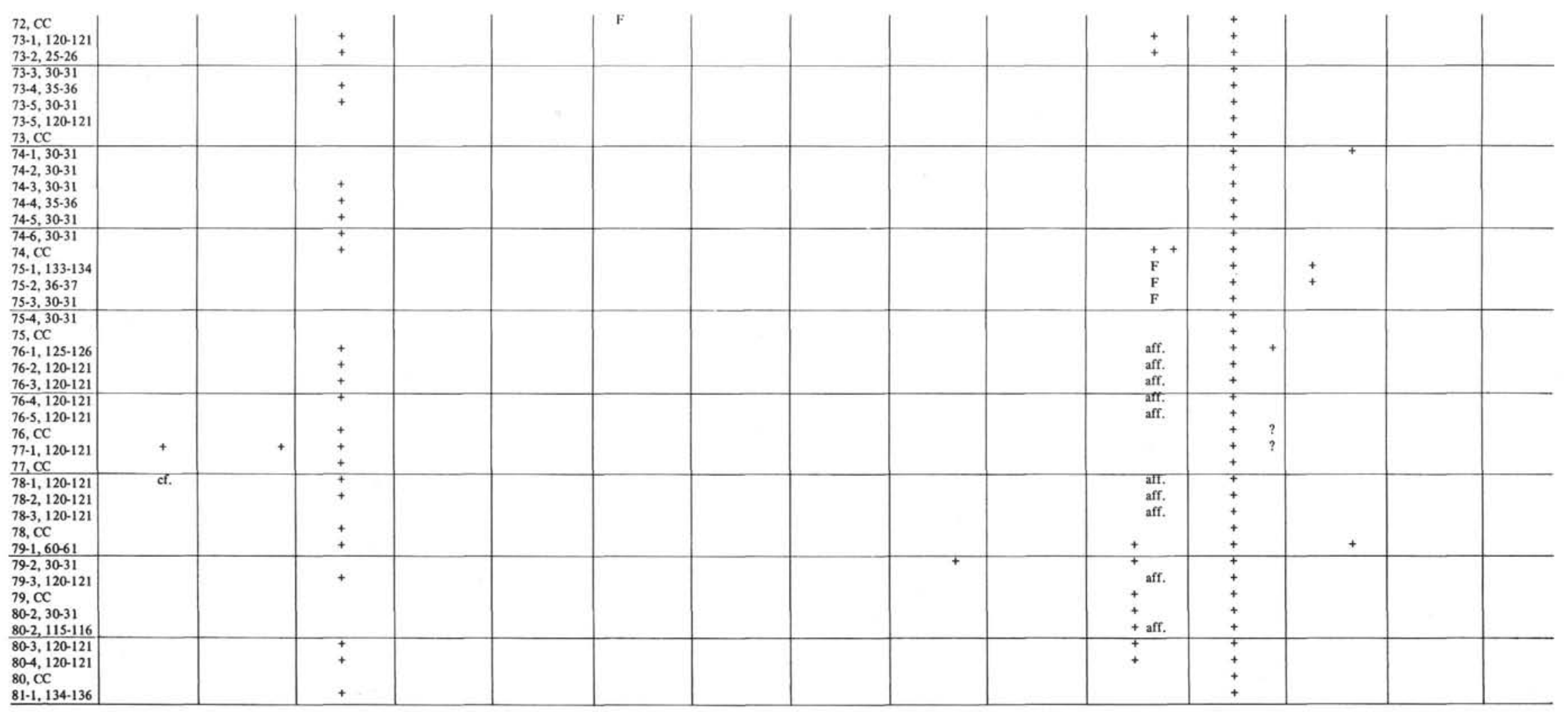




\begin{tabular}{|c|c|c|c|c|c|c|c|c|c|c|c|c|c|c|c|}
\hline Species & 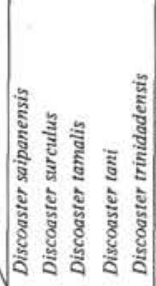 & 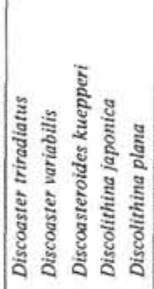 & 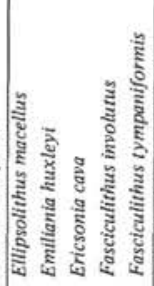 & 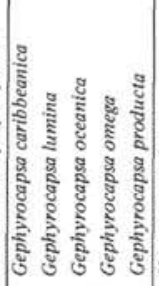 & 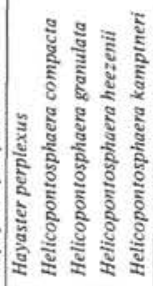 & 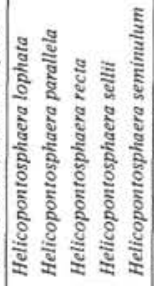 & 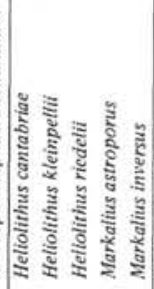 & 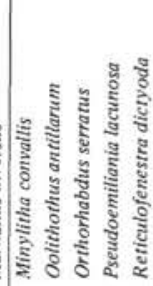 & 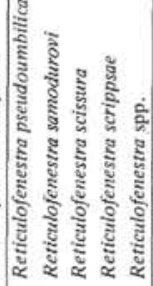 & 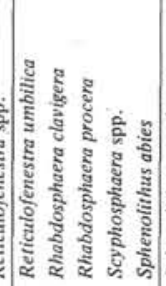 & 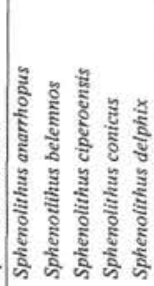 & 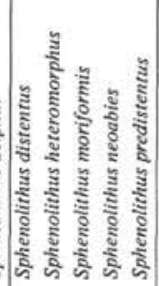 & 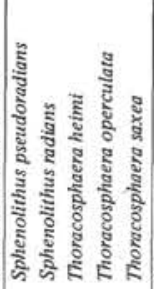 & 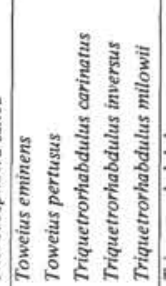 & 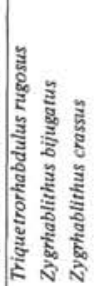 \\
\hline $\begin{array}{l}81-2,125-126 \\
81, C \mathrm{C} \\
82-1,30-31 \\
82-2,30-31 \\
82-2,120-121\end{array}$ & & & $\begin{array}{l}+ \\
+ \\
+ \\
+ \\
\end{array}$ & & & & & & & & $\begin{array}{l}+ \\
+ \\
+ \text { aff. } \\
+\end{array}$ & $\begin{array}{l}+ \\
+ \\
+ \\
+ \\
+\end{array}$ & + & & \\
\hline $\begin{array}{l}82-3,30-31 \\
82-3,120-121 \\
82, \mathrm{CC} \\
83-1,112-113 \\
83-2,120-121\end{array}$ & & & $\begin{array}{l}+ \\
+ \\
+ \\
+ \\
\end{array}$ & & & F & & & & & $\begin{array}{l}+ \\
+ \\
+ \\
+ \\
+ \\
\end{array}$ & $\begin{array}{l}+ \\
+ \\
+ \\
+ \\
+\end{array}$ & & & \\
\hline $\begin{array}{l}83, \mathrm{CC} \\
84-1,124-125 \\
84-2,39-40 \\
84-2,101-102 \\
84, C C\end{array}$ & & & $\begin{array}{l}+ \\
+ \\
+ \\
+\end{array}$ & & & & + & & & - & $\begin{array}{l}+ \text { aff. } \\
+ \\
+ \\
+\end{array}$ & $\begin{array}{ll} & + \\
& + \\
& + \\
& + \\
+ & + \\
\end{array}$ & & $\begin{array}{l}+ \\
+\end{array}$ & \\
\hline $\begin{array}{l}85-1.28-29 \\
85-1,119-122 \\
85, C C \\
86-2,120-121 \\
86-3,120-121 \\
\end{array}$ & & & $\begin{array}{l}+ \\
+ \\
+ \\
+ \\
+\end{array}$ & & & + & & & & & $\begin{array}{l}+ \\
+ \\
\text { aff. } \\
\text { aff. }\end{array}$ & $\begin{array}{lll}+ & + & + \\
+ & + & + \\
+ & + & + \\
+ & + & + \\
+ & + & + \\
+ & + & +\end{array}$ & & & \\
\hline $\begin{array}{l}86-4,120-121 \\
86-5,120-121 \\
86-6,120-121 \\
86, \mathrm{CC} \\
87-2,40-41\end{array}$ & & & $\begin{array}{l}+ \\
+ \\
+ \\
+ \\
+\end{array}$ & & & & & & + & & $\begin{array}{l}\text { aff. } \\
\text { aff. } \\
\text { aff. }\end{array}$ & $\begin{array}{lll}+ & + & + \\
& + & + \\
+ & + & + \\
+ & + & + \\
+ & + & + \\
\end{array}$ & & + & \\
\hline $\begin{array}{l}87-2,120-121 \\
87, C C \\
88-1,134-135 \\
88-2,125-126 \\
88-3,114-116\end{array}$ & & & $\begin{array}{l}+ \\
+ \\
+ \\
+ \\
+\end{array}$ & & & + & & & & & $\begin{array}{l}\text { aff. } \\
\text { aff. }\end{array}$ & $\begin{array}{lll}+ & + & + \\
+ & + & + \\
+ & + & + \\
+ & + & + \\
+ & + & +\end{array}$ & & & \\
\hline $\begin{array}{l}88, \mathrm{CC} \\
89-1,120-121 \\
89-2,120-121 \\
89-3,120-121 \\
89-4,120-121 \\
\end{array}$ & & & $\begin{array}{l}+ \\
+ \\
+ \\
+ \\
+\end{array}$ & & & & & & & & & $\begin{array}{rll}+ & + & + \\
& + & + \\
+ & + & + \\
& + & + \\
+ & + & +\end{array}$ & & & \\
\hline $\begin{array}{l}89, \mathrm{CC} \\
90-1,120-121 \\
90-2,130-131 \\
90-3,126-127 \\
90, \mathrm{CC}\end{array}$ & 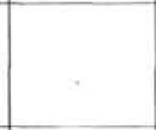 & & $\begin{array}{l}+ \\
+ \\
+ \\
+ \\
+\end{array}$ & & & & & & & & aff. & $\begin{array}{lll}+ & + & + \\
+ & + & + \\
+ & + & + \\
+ & + & + \\
+ & + & + \\
+ & + & + \\
\end{array}$ & + & & + \\
\hline $\begin{array}{l}91-1,120-121 \\
91-2,120-121 \\
91-3,120-121 \\
91-4,120-121 \\
91-5,120-121 \\
\end{array}$ & & & $\begin{array}{l}+ \\
+ \\
+ \\
+ \\
+\end{array}$ & & $\stackrel{+}{+}$ & + & & & $\begin{array}{l}+ \\
+ \\
+ \\
+\end{array}$ & & & $\begin{array}{rll} & + & + \\
+ & + & + \\
+ & + & + \\
& + & + \\
+ & + & +\end{array}$ & & & \\
\hline $\begin{array}{l}91 . \mathrm{CC} \\
92-1,120-121 \\
92, \mathrm{CC} \\
93-1,120-121 \\
93-2,120-121\end{array}$ & & & $\begin{array}{l}+ \\
+ \\
+ \\
+ \\
+\end{array}$ & & & & & & $\begin{array}{l}++ \\
++ \\
+\end{array}$ & & & $\begin{array}{ccc}+ & + & + \\
\text { iff. } & + & + \\
& + & + \\
& + & + \\
\text { fiff. } & + & +\end{array}$ & + & & $\begin{array}{l}+ \\
+\end{array}$ \\
\hline $\begin{array}{l}93-3,120-121 \\
93, \mathrm{CC} \\
94-1,130-131 \\
94-2,120-121 \\
94-3,120-121\end{array}$ & & & $\begin{array}{l}+ \\
+ \\
+ \\
+ \\
+\end{array}$ & & $\begin{array}{l}+ \\
+ \\
+\end{array}$ & & & & $\begin{array}{r}+ \\
+ \\
+ \\
+ \\
+\end{array}$ & & & $\begin{array}{ll}+ & + \\
+ & + \\
+ & + \\
+ & + \\
+ & + \\
\end{array}$ & & & $\begin{array}{l}+ \\
+ \\
+ \\
\end{array}$ \\
\hline $\begin{array}{l}94-4,130-131 \\
94, C C\end{array}$ & & & $\begin{array}{l}+ \\
+ \\
+\end{array}$ & & & & & & & & & $\begin{array}{ll}+ & + \\
+ & +\end{array}$ & & & \\
\hline
\end{tabular}




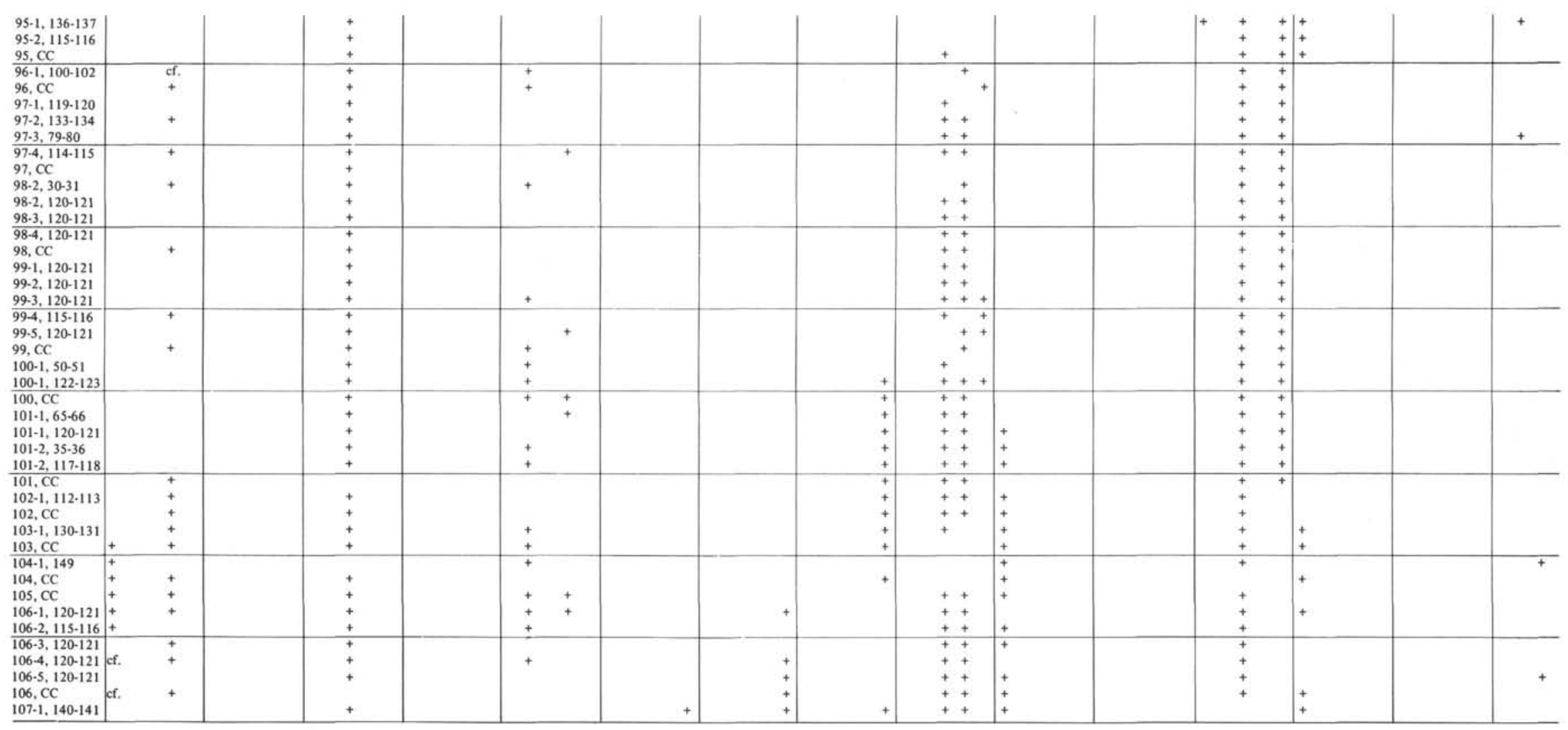




\section{S. SHAFIK}

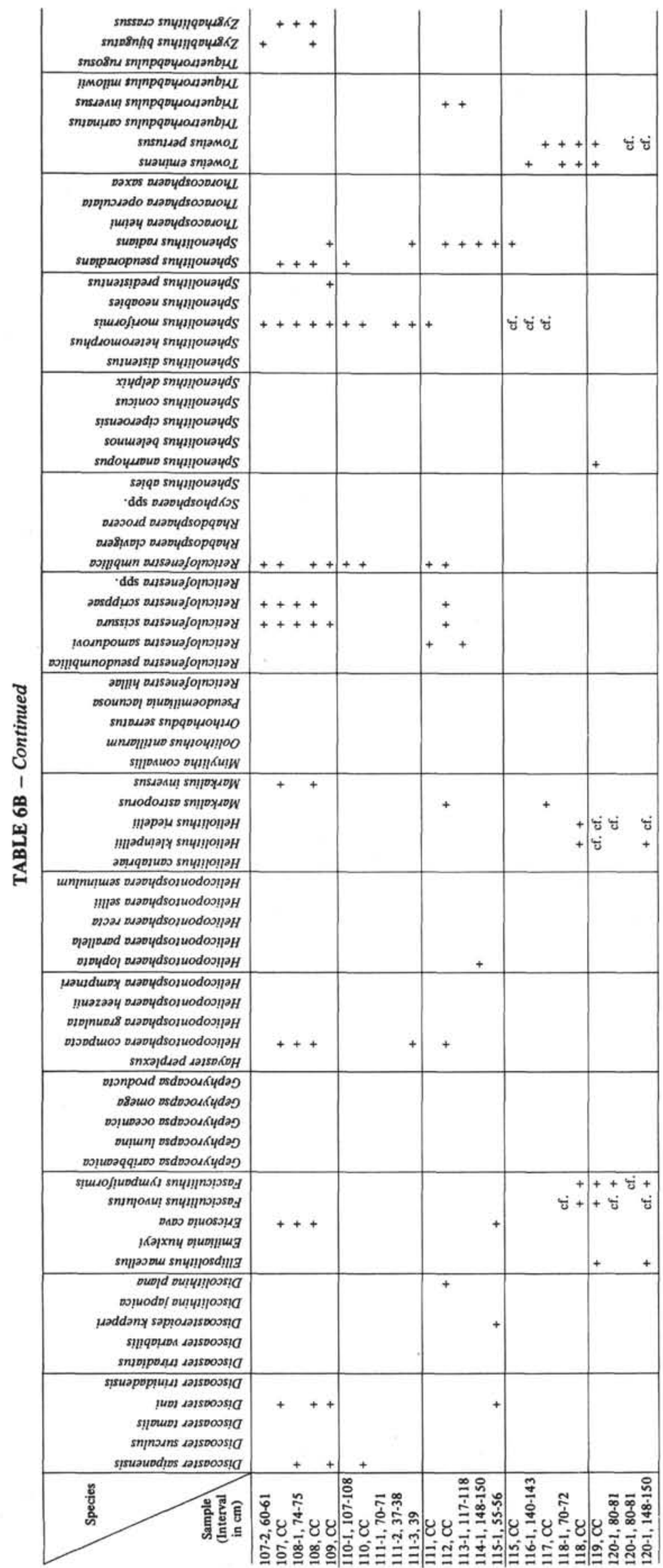

TABLE 7

Upper Tertiary-Ouaternary Hiatuses Detected by the Use of Nannofossils, Absolute Ages Slightly Modified After Rnkrv (1973d)

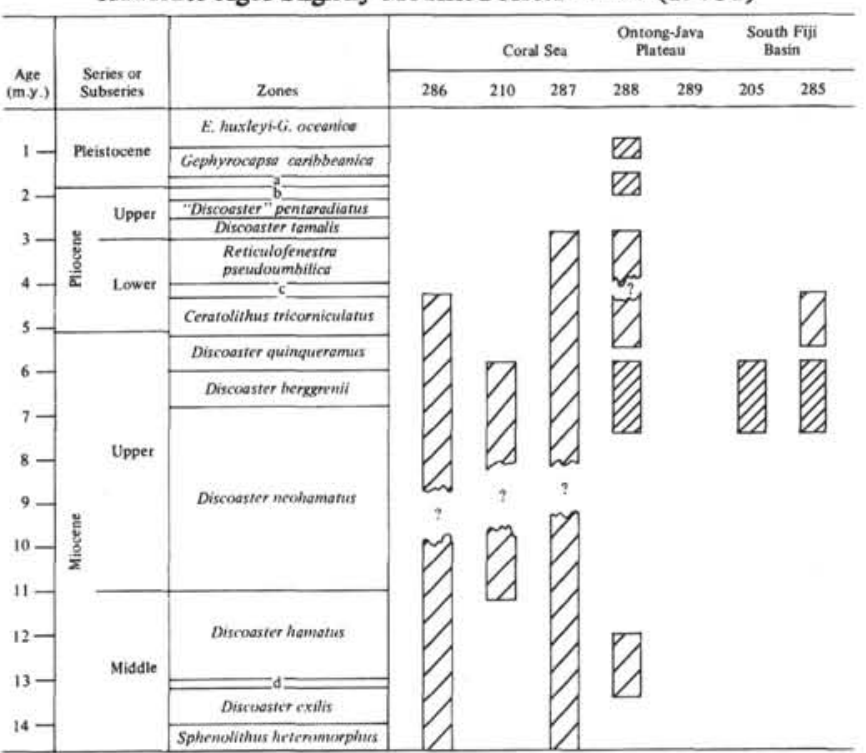

Note: Devidence gond, Devidence reasmable, Devidence tenuave

Previdoemiliania focumises

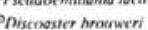

Ceretolithas rugosos

Catimester coalinus

TABLE 8

Lower Tertiary Hiatuses Detected by the Use of Nannofossils, Absolute Ages Slightly Modified After Bukry (1973d)

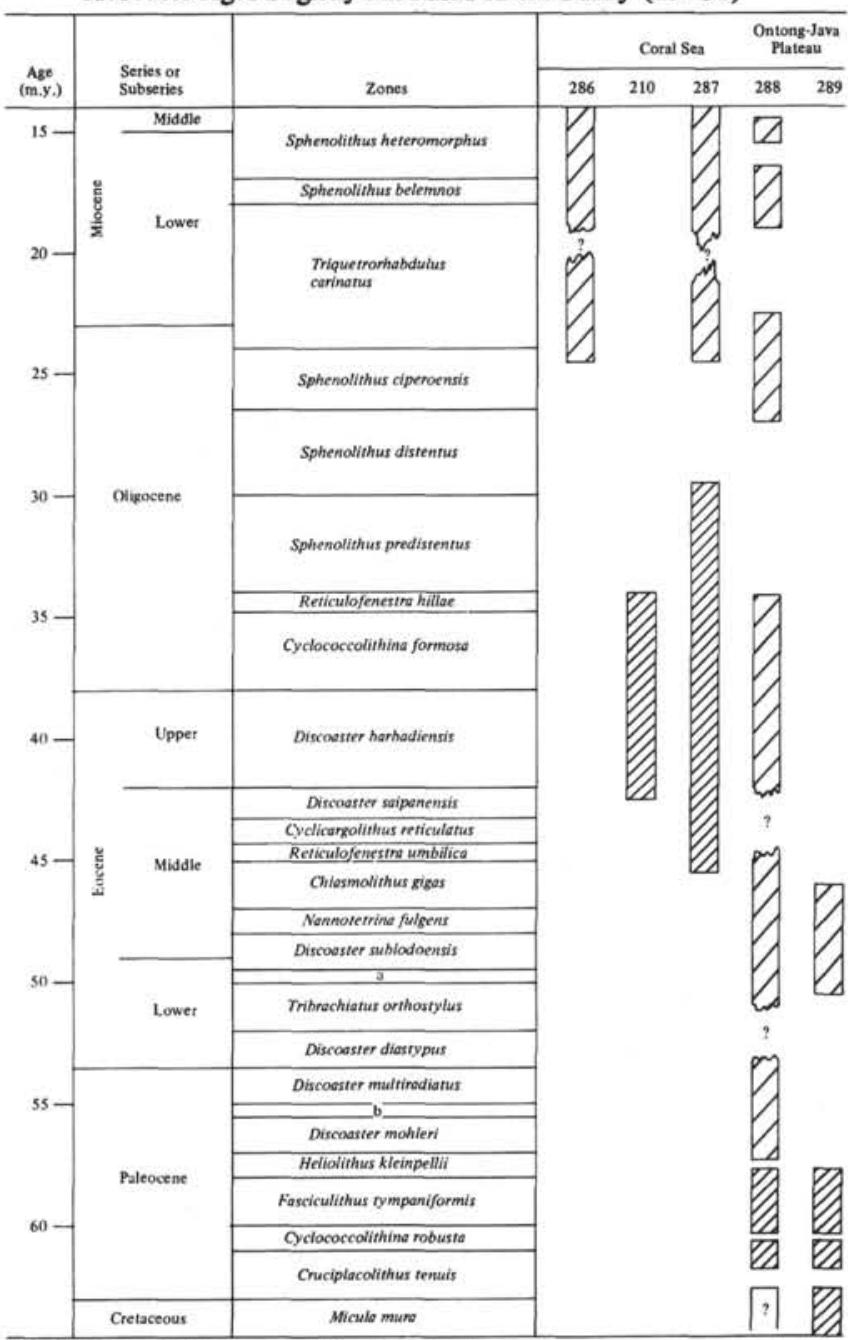

Note: $\square$ evidence good, $\square$ evidence reasonable, $\square$ evidence tenuous

Discoaster lodocusii

Discoester nobilits 
allocations. A possible existence of a hiatus between Sections 2 and 3 cannot be ruled out since the sequence of the paleontological events is largely masked by reworking.

\section{Miocene}

The upper Miocene sediments in most of the southwest Pacific region either contain an unconformity or are relatively thin and almost totally barren of calcareous microplankton remains and virtually becoming absent. The unconformity is usually represented by the absence of the Discoaster berggrenii Zone.

In the South Fiji Basin, the two sites (205 and 285) preserve a hiatus between the upper Miocene Discoaster quinqueramus and D. neohamatus zones. Sample 205-4, CC contains, among the assemblage listed by Edwards (1973, Table 5), D. quinqueramus, D. berggrenii, and Ceratolithus tricorniculatus and therefore fits in the $D$. quinqueramus Zone (sensu this chapter). Section 205-5-1 belongs to the lower subzone of the $D$. neohamatus Zone according to Bukry (1973c). A hiatus between these cores is therefore inferred; a lithologic boundary at or near this level is recorded by Burns, Andrews, et al. (1973). A similar and almost identical hiatus is recorded at Site 285 (this volume) between the $D$. quinqueramus Zone (base, sample $285-3-1,36-37 \mathrm{~cm}$ ) and the $D$. neohamatus Zone (top, Sample 285-3-2, 51-52 cm). Surprisingly, the hiatus established at Site 285 is almost at the same level below the present sea floor as the one deduced at Site 205.

In the Coral Sea, there are indications suggesting a rather different history for the Miocene; hiatuses seem to be enlarged and/or deposition was essentially below the total nannofossil solution depth. Section 210-29-4 is placed in the Ceratolithus primus Subzone (Bukry, 1973c) which correlates with the D. quinqueramus Zone (sensu this chapter), and Section 210-30-1 is assigned to the Discoaster hamatus Zone (Edwards, 1973. It seems rather unlikely that the segment between these two cores (ca $12 \mathrm{~m}$ ) contains, in addition to the long $D$. neohamatus Zone (ca 4.2 m.y.: Bukry, 1973b), the $D$. berggrenii Zone; a hiatus is therefore inferred. At Site 287, the sediments between the upper Pliocene Sample $287-8-1,10-11 \mathrm{~cm}$ and the upper Oligocene Sample $287-$ $16-2,4-5 \mathrm{~cm}$ are essentially devoid of nannofossils; the whole Miocene is barren and unconformity is likely.

At Site 286, between the South Fiji Basin and the Coral Sea, the Miocene sediments are scarcely fossiliferous, exceptionally thin (maximum thickness: 19 $\mathrm{m}$ ), and appear in the major part of Core 286-5; existence of a hiatus cannot be ruled out.

At Site 288 on the Ontong-Java Plateau, a hiatus similar to that recognized at the South Fiji Basin sites is established. The hiatus is represented by the absence of the $D$. berggrenii Zone between the $D$. quinqueramus Zone (Sample 288-6-6, 30-31 cm) and the D. neohamatus Zone (Sample 288-6-6, 120-121 cm).

Sample 288-8-1, 118-119 cm belongs to the Catinaster calyculus Subzone (D. hamatus Zone) and Sample 288-8, CC to the Discoaster exilis Zone; the relatively thin Helicopontosphaera kamptneri Subzone and Catinaster coalitus Zone were not identified. The poor recovery of Core 288-8 and to a lesser degree the short span of the unidentified biostratigraphic units make recognition of a hiatus largely uncertain. Within the Sphenolithus heteromorphus Zone, a hiatus probably exists on the evidence of a sharp drop in the abundance of Discoaster deflandrei between Samples 288-10, CC and 288-10-2, 123-124 cm; notwithstanding, this may indicate a biostratigraphic boundary (see Bukry, 1973d for the $S$. heteromorphus-Helicophontosphaera ampliapertura zonal boundary). Poor preservation of the nannofossils and poor recovery of Core 288-10 sediments cause uncertainty in establishing a hiatus. Similarly, two doubtful hiatuses may be contained in the noncoring gaps between 288-11, CC and 288A-1-1 and between 288A-2, CC and 288A-3-1. Core 288-11 belongs to the $S$. heteromorphus Zone and Core 288A-1 is placed in the Discoaster druggii Subzone (Triquetrorhabdus carinatus Zone). Core 288A-2 is assigned to the Discoaster deflandrei Subzone (Triquetrorhabdus carinatus Zone) and 288A-3 belongs to the Sphenolithus distentus Zone.

\section{Eocene-Oligocene}

The Eocene-Oligocene regional unconformity in the Coral Sea recognized at Site 210 (Burns, Andrew, et al., 1973 ) is recorded at Site 287. Sample 287-11-0, 24-25 cm belongs to the upper Oligocene $S$. distentus Zone and Sample 287-11-0, 29-30 $\mathrm{cm}$ is within the middle middle Eocene Chiasmolithus gigas Zone; a distinct lithologic break occurs in 287-11-0 at $27 \mathrm{~cm}$. The hiatus at Site 287 is of greater magnitude than that recorded at Site 210 where it appears to be between the lower Oligocene Core 210-34 and the upper middle Eocene Core 35 (see Edwards, 1973).

A hiatus is suspected between the lower Oligocene Core 228A-6 and the Paleocene Core 288A-8; the fossils in Core 288A-6 are drastically mixed and no recovery was obtained for Core 288A-7. At Site 289, however, Eocene sediments were recovered and a hiatus is suspected within the lower Oligocene-upper Eocene Core 289-102. Another hiatus is detected between the middle Eocene $C$. gigas Zone Sample 289-113-1, 117-118 $\mathrm{cm}$ and the lower Eocene Discoaster lodoensis Zone Sample 289-114-1, 148-150 cm; samples investigated are limited by poor recovery. A doubtful hiatus may exist within the lower Eocene sediments of Site 289 (Core115).

\section{Paleocene}

A hiatus is suspected between the Discoaster multiradiatus Zone Core 289-119, CC and the Discoaster mohleri Zone Core 120-1, $80-81 \mathrm{~cm}$. Two intra-Paleocene hiatuses associated with increases in reworked forms, are recognized at Site 288. Sample 288A-8-2, $102-103 \mathrm{~cm}$ is placed tentatively in the Heliolithus kleinpellii Zone and Sample 2-8A-8-2, 138-139 cm is assigned to the Cruciplacolithus tenuis Zone. Sample $288 \mathrm{~A}-8-2,122-123 \mathrm{~cm}$ is high in the Cyclococcolithina robusta Zone indicating a position bracketed by two hiatuses. A similar situation is detected at Site 289. Two 
hiatuses separate the $C$. robusta Zone (Samples 289-121$1,125-126 \mathrm{~cm}$ and $289-121-2,62-63 \mathrm{~cm}$ from the overlying $H$. kleinpellii Zone Sample 289-120, CC and the underlying $C$. tenuis Zone Sample 289-121 (top).

\section{Cretaceous}

The Cretaceous-Tertiary boundary at Site 288 is in noncored segment, but it was recovered at Site 289; poor preservation of the nannofossils straddling the boundary (in Core 289-122) hinders elucidating its nature; however, a part of the Maestrichtian seems to be missing.

The Upper Cretaceous sediments at Site 288 probably contain two hiatuses. Between the Tetralithus trifidus Zone (base, Sample 288A-11-2, 29-30 cm and the Eiffellithus augustus Zone (top, Sample 288A-11-2, 100$102 \mathrm{~cm}$ ) the Broinsonia parca Zone may occur in Sample $288 \mathrm{~A}-11-2,80-81 \mathrm{~cm}$, suggesting however, an intraCampanian hiatus.

The other possible hiatus is between the E. augustus Zone (base, 288A-12-1, 122-125 cm) and the Marthasterites furcatus Zone (top, 288A-12, CC) on account of the apparent absence of Gartnerago obliquum Zone; poor recovery of Core 288A-12 renders establishing a hiatus uncertain.

At Site 289 , a drop in the diversity and quality of preservation of the nannofossils associated with the occurrence of barren levels occur in Section 289-131-1 separating the Campanian E. augustus Zone Sample 239-131-1, 2-4 cm from the probably Aptian Sample $289-131-2,10-14 \mathrm{~cm}$.

\section{ACKNOWLEDGMENT}

The study was carried out during the tenure of a Commonwealth Postgraduate Scholarship. Dr. B. McGowran of the University of Adelaide critically read the manuscript.

\section{REFERENCES}

Bukry, D.A., 1973a. Coccolith stratigraphy Leg 13, Deep Sea Drilling Project. In Ryan, W.B.F., Hsu, K.J., et al., Initial Reports of the Deep Sea Drilling Project, Volume 13: Washington (U.S. Government Printing Office), p. 817. 1973b. Coccolith stratigraphy Leg 16, Deep Sea Drilling Project. In van Andel, T.H., Heath, G.R., et al., Initial Reports of the Deep Sea Drilling Project, Volume 16: Washington (U.S. Government Printing Office), p. 653. , 1973c. Coccolith and silicoflagellate stratigraphy, Tasman Sea and southwestern Pacific Ocean, Deep Sea Drilling Project Leg 21. In Burns, R.E., Andrews, J.E., et al., Initial Reports of the Deep Sea Drilling Project, Volume 21: Washington (U.S. Government Printing Office), p. 885

1973d. Low-latitude coccolith biostratigraphic zonation. In Edgar, N.T., Saunders, J.B., et al., Initial Reports of the Deep Sea Drilling Project, Volume 15: Washington (U.S. Government Printing Office), p. 685.

Burns, R.E., Andrews, J.E., et al., 1973. Initial Reports of the Deep Sea Drilling Project, Volume 21: Washington (U.S. Government Printing Office).

Edwards, A.R., 1973. Calcareous nannofossils. In Burns, R.E., Andrews, J.E., et al., Initial Reports of the Deep Sea Drilling Project, Volume 21: Washington (U.S. Government Printing Office), p. 641.

Gartner, S., Jr., 1969. Correlation of Neogene planktonic foraminifer and calcareous nannofossil zones: Gulf Coast Assoc. Geol. Soc. Trans., v. 19, p. 585.

1974. Nannofossil biostratigraphy, Leg 22, Deep Sea Project. In van der Borch, C.C., Sclater, J.G., et al., Initial Reports of the Deep Sea Drilling Project, Volume 22: Washington (U.S. Government Printing Office), p. 577.

Roth, P.H., 1973. Calcareous nannofossils-Leg 17, Deep Sea Drilling Project. In Winterer, E.L., Ewing, J.I., et al., Initial Reports of the Deep Sea Drilling Project, Volume 17: Washington (U.S. Government Printing Office), p. 695. 